CASTILLO, Ignacio. "Enjuiciando al proceso penal chileno desde el inocentrismo (algunos apuntes sobre la necesidad de tomarse en serio a los inocentes)."

Polít. crim. Vol. 8, No 15 (Julio 2013), Art. 7, pp. 249 - 313.

[http://www.politicacriminal.cl/Vol_08/n_15/Vol8N15A6.pdf]

\title{
Enjuiciando al proceso penal chileno desde el inocentrismo (algunos apuntes sobre la necesidad de tomarse en serio a los inocentes) ${ }^{1}$
}

\author{
Ignacio Castillo Val \\ Magíster Universidad Alberto Hurtado \\ Doctor (c), Università degli Studi di Milano \\ Investigador Centro de Estudios de Derecho Penal \\ Universidad de Talca \\ igcastillo@utalca.cl
}

\section{Resumen}

Pretender que nunca se condene a un imputado fácticamente inocente es una tarea que ningún proceso penal se propondría alcanzar, aquello es imposible. Los sistemas penales condenan gente inocente y el inocentrismo se ha encargado, en algunos países más que en otros, de demostrarlo. El presente trabajo se propone, a la luz de la información empírica y teórica que ha surgido desde el movimiento inocentrista, analizar críticamente nuestro proceso penal para llamar la atención sobre su vulnerabilidad para prevenirlas. Junto a ello, el texto sugiere varias modificaciones en distintos ámbitos del tratamiento de la evidencia y propone revisar la adversarialidad del modelo que, por su insuficiente regulación, hoy resulta un problema más que una solución al objetivo de reducir las condenas a imputados fácticamente inocentes.

\section{Palabras claves}

Inocentrismo, condenas de inocentes, adversarialidad, evidencia.

\begin{abstract}
Attempts to always avoid the conviction of factually innocent defendants is a task that no criminal proceedings would aim to achieve, it is unfeasible. In fact, criminal systems condemn innocent people, and the Innocence Movement has been responsible -in some countries more than in others- of proving it. This paper proposes, over the basis of the empirical and theoretical information that has emerged from this movement, to analyze in a critical perspective our criminal process and to draw attention to its vulnerability to prevent the conviction of innocents. Along with this, the paper suggests several changes
\end{abstract}

\footnotetext{
${ }^{1}$ El presente paper constituye una versión acortada del trabajo presentado para obtener el grado de Magíster en Derecho Penal y Procesal Penal, otorgado por la Universidad Alberto Hurtado de Chile. Quisiera agradecer a Gonzalo Medina S., quien fue mi tutor de tesis, por sus valiosos comentarios, críticas y sugerencias. Lo mismo a los miembros del Tribunal evaluador, compuesto por Luis Emilio Rojas, Rodrigo Aldoney, Gonzalo García, además de mi tutor. A Raúl Carnevali y a Carlos Cabezas por la primera revisión del texto, ambos me ayudaron a decidir el camino que debía seguir. A Pelayo Vial y Danilo Báez por la revisión final del artículo. Debo también agradecer a Sonia Gómez, de la biblioteca de la Universidad de Talca quien, pese a la distancia, siempre se esforzó en ayudarme. Last but not least a Francesco Viganò por sus acertados consejos y a Valeria Aldana por su valiosísima ayuda en la corrección final del texto.
} 
CASTILLO, Ignacio. "Enjuiciando al proceso penal chileno desde el inocentrismo (algunos apuntes sobre la necesidad de tomarse en serio a los inocentes)."

in the different scopes of treatment of evidence, and suggests a review of the adversarial model because, due to its insufficient regulation, its goal of reducing convictions of factually innocent defendants is currently more a problem than a solution.

\section{Key words}

Innocentrism, innocents convicted, adversarial, evidence.

\section{Introducción}

"Mejor ejecutar diez hombres inocentes que dejar libre a un hombre culpable"

Feliks Dzerzhinsky

Fundador de la Policía Secreta Rusa. ${ }^{2}$

“...que las condenas erróneas, cuantas ellas sean, son simplemente el precio de la seguridad, y que los erróneamente condenados deberían ser vistos como necesarios, incluso honorables víctimas de la guerra contra el crimen".

William Paley ${ }^{3}$

El ex Pdte. de la Corte Suprema de Chile expresó, en una entrevista concedida a la Defensoría Penal Pública, que no veía temas pendientes en el nuevo proceso penal y que, por el contrario, le impresionaba positivamente y lo catalogaba como exitoso. ${ }^{4}$ Esta posición se ha expandido entre los actores del sistema, entre quienes participaron en su diseño e implementación y, en definitiva, en buena parte de quienes se vinculan a él. Y es que hay buenas razones - desde la perspectiva de la implementación de una política pública- para compartir esa opinión, pues la reforma procesal penal implicó una transformación radical en nuestro sistema de justicia criminal y es, además, observada en el exterior como un referente en los procesos de reforma judicial en América Latina.

Sin embargo, si uno analiza el funcionamiento del modelo de enjuiciamiento criminal chileno en profundidad -y en ciertos aspectos revisa críticamente su normativa-, podrá advertir que esa valoración condescendiente resulta excesiva e inconveniente. Una observación acuciosa, por el contrario, pareciera indicar que el proceso penal, al revés de lo sostenido por el Ministro Juica, tiene varios "temas pendientes" y que la prudencia

\footnotetext{
2 Cit. en VOLOKH, Alexander, "N Guilty Men", University Of Pennsylvania Law Review Vol. 146, (1997-1998), pp. 173-216, ps. 195-196. [Nota: Salvo que se indique expresamente lo contrario, las traducciones de los textos utilizados en el presente paper son de mi autoría].

${ }^{3}$ PALEY, William, The Principles of Moral and Political Philosophy, Indianapolis: Liberty Fund, 2002, p. 553.

4 En "A confesión de parte, entrevista a Milton Juica A", Revista 93, 10 años de la Reforma Procesal Penal, Revista de la Defensoría Penal Pública, Vol. N 4, (2010), pp. 6-9, p. 6. Con algunas excepciones menores, como la nota a la ex Defensora Nacional Paula Vial, en el resto de la revista también se observa una marcada tendencia complaciente con el modelo de enjuiciamiento criminal chileno. En el mismo sentido pueden verse los textos de presentación del libro publicado por el Ministerio de Justicia, en ocasión de los 10 años de la reforma procesal penal. AA.VV., 10 años de la Reforma Procesal Penal: Los desafíos del nuevo sistema, Santiago: Ministerio de Justicia, 2010, pp. 9-38.
} 
sugiere que ellos sean debatidos, enfrentados y resueltos a la brevedad, ${ }^{5}$ porque hoy existe el riesgo - más allá de lo razonable- que estemos asumiendo como exitoso un modelo de enjuiciamiento que, a pesar de sus destacados logros cuantitativos, esté produciendo resultados cualitativamente diversos a los esperados como, por ejemplo, condenar a inocentes.

La necesidad de revisar el proceso penal surge, según sostendré en este trabajo, porque éste presenta un diseño estructural que todavía se observa con demasiada admiración, a pesar de que ha comenzado a exhibir ciertos rasgos inquietantes (aunque predecibles), me refiero, en concreto, a la forma en que se ha ido consolidando la adversarialidad ${ }^{6}$ y

\footnotetext{
${ }^{5}$ Es cierto que han existido numerosos aspectos puntuales del Código Procesal Penal (en adelante CPP) que han sido fuertemente cuestionados por la comunidad académica, pero que, en todo caso, se han centrado en institutos particulares del proceso y, en general, han sido bastante condescendientes con la estructura adversarial que se plasmó legislativamente y que se ha ido consolidando. Así, por ejemplo, se ha cuestionado el control de identidad, la ampliación de las hipótesis de flagrancia, la regulación -y las modificaciones que la han deformando- de la prisión preventiva, la utilización y el modo en que hoy se ejerce por el Ministerio Público el principio de oportunidad, los mecanismos de simplificación procesal, el estándar de convicción del juicio oral, y un largo etc., pero casi siempre desde una perspectiva acrítica al modelo adversarial penal. Una excepción a esta posición se aprecia en el agudo trabajo de Del Rio sobre dos aspectos trascendentales del sistema procesal penal chileno, a saber, el principio del consenso y la garantía de no agravación punitiva que, en la forma en que hoy operan en Chile, claramente ponen en duda el carácter cognoscitivo del proceso penal. Véase, DEL RIO, Carlos, "Dos formas discutibles de poner en duda el carácter cognoscitivo de la aplicación judicial del Derecho penal: el principio de consenso y la garantía de la no agravación punitiva", Revista de Derecho de la Pontificia Universidad Católica de Valparaíso, Vol. N XXXIV (2010), pp. 349-383.

${ }^{6}$ Según Damaška, se puede entender la adversarialidad como "un sistema de adjudicación en que la acción del proceso es controlada por las partes y el adjudicador se mantiene esencialmente pasivo en el ámbito de la determinación de los hechos, esto implica que los litigantes y sus abogados deciden qué hechos deberían ser objeto de pruebas". Implica, además, que los clientes y sus abogados están llamados a buscar la evidencia material, prepararla para ser usada en el juicio y presentarla al tribunal. DAMAŠKA, Mirjan, Evidence Law Adrift, New Haven: Yale University Press, 1997, p. 74. También la adversarialidad puede ser apreciada desde otras perspectivas. Así, por ejemplo, Kagan analiza la adversarialidad del sistema estadounidense desde una perspectiva más global, relacionada con la forma en que se comporta la sociedad al momento de enfrentar sus distintos desafíos o dificultades (políticos, sociales, morales, etc.). De hecho, en palabras de Taruffo, quien hace la presentación del libro de Kagan en la edición italiana, el modelo adversarial no sería "una categoría conceptual, ni un modelo teórico, sino que es por lo demás una definición de una actitud, de una praxis difusa en todas las áreas del sistema jurídico, que consiste en la preferencia -respecto de otros modelos para enfrentar problemas jurídicos, económicos y sociales- del método de la competencia formal dominada por las partes en conflicto", con la "ausencia de instituciones capaces de direccionar la solución de los conflictos a canales más eficientes, menos costosos y menos complicados". Véase, KAGAN, Robert, La giustizia americana: come il contradditorio fa il diritto, Ed. Italiana: TARUFFO, Michele (Dir.), Bologna: Il Mulino, 2009. Asimismo, se puede también analizar el modelo adversarial desde una mirada económica, en el sentido de que éste refuerza ciertos valores culturales como el individualismo y la competición que, como lo explica Strier (citando a Cheatham), permiten ver al modelo adversarial como la otra cara de la moneda del laissez-faire, el fundamento teórico del capitalismo. De hecho, según el autor "es un modelo que incentiva la competencia, que refleja la ideología política clásica del liberalismo inglés, a saber, el énfasis en el interés individual y la iniciativa particular, por la desconfianza al Estado (a los jueces) y la significación que se le atribuye a la participación de las partes. Estas condiciones, dicho sea de paso, son las que subyacen la concepción de Smith sobre la sociedad de mercado, en la que la mano invisible de la competición transforma el conflicto entre intereses privados en la realización de los intereses públicos". Al respecto véase, STRIER, Franklin, "Major Problems Endemic to the Adversary System and Proposed Reform", Western State University Law Review, Vol. N ${ }^{\circ}$ 19, (1991-1992), pp. 463-492, pp. 463 y ss. Apoyando esta tesis Saltzburg, para quien la "justificación [del modelo adversarial] se funda en que las personas que buscan ganar o perder en las transacciones están más motivadas para actuar más eficientemente que aquellos que son indiferentes al
} 
CASTILLO, Ignacio. "Enjuiciando al proceso penal chileno desde el inocentrismo (algunos apuntes sobre la necesidad de tomarse en serio a los inocentes)."

cómo ello ha forjado un modelo que en la práctica evidencia una indiscutible falta de regulación, control y transparencia en como las partes descubren o generan la evidencia que luego presentan -o no, según su discreción - al proceso, en particular al juicio oral, muchas veces con una excesiva visión de túnel. Todo ello afecta la calidad de la evidencia necesaria para corroborar o refutar las proposiciones sobre los hechos imputados. En particular, esto se observa en algunas diligencias de investigación que son trascendentales, a saber, las confesiones, los reconocimientos, los peritajes; sumado a la forma en que se presenta y se prepara la prueba testimonial y pericial para el juicio oral. Todo ello crea, según lo ha destacado la doctrina comparada, un evidente riesgo de que se produzcan condenas a imputados fácticamente inocentes (en adelante imputados "finocentes"). ${ }^{7}$

Para los fines del presente trabajo existe una importante diferencia entre los " $f$ inocentes" y los normativamente inocentes (" $n$ inocentes"). Así, los primeros son inocentes porque no han cometido el delito que se les imputa, sea porque el verdadero autor fue un tercero o porque el delito no existió; y los segundos, aunque realmente culpables del delito, son declarados inocentes por razones normativas, sea porque el Ministerio Público no pudo alcanzar el estándar de prueba necesario para obtener una condena, porque parte importante de la evidencia no pudo ser utilizada en el juicio (v.gr. si fue excluida por haber sido obtenida con inobservancia de garantías fundamentales, o por la protección del ejercicio de ciertos privilegios o derechos -familiares, profesionales, entre otras), o porque transcurrió el plazo de prescripción de la acción penal, etc. ${ }^{8}$ Es evidente que, finalmente, todos ellos son inocentes porque el Estado no

resultado de la transacción comercial". Véase, SALTZBURG, Stephen, "Lawyers, Clients, and the Adversary System”, Mercer Law Review Vol. N 37, (1985-1986), pp. 647-700, p. 656. Por último, se puede anunciar acá que, como lo propone Frankel, también se puede analizar críticamente el sistema procesal adversarial en el derecho civil (en cuanto entrega el conflicto a las partes) desde una perspectiva sociológica, en especial al modelo de sociedad en que se inserta. En efecto, como lo dice el autor citado, el sistema adversarial va generando -como en los negocios- un "régimen de competitividad, de lucha, liberando a las partes a una guerra entre ellas, imponiendo [los abogados] en gran medida la lógica a sus representados; la idea de que gana el más fuerte, el más astuto, el que sabe decir lo que el tribunal quiere escuchar". FRANKEL, Marvin, Partisan Justice. Too much fight? Too little truth? Equal Justice? New York: Hill and Wang, 1978, pp. 11 y ss.

${ }^{7}$ Es claro que un Estado de Derecho no puede permitirse una actitud condescendiente con la condena de un inocente, ni aún a pretexto de que con ello se pueda mantener un nivel de condena que permita proteger a la ciudadanía. Condenar a un imputado " $f$ inocente" es una situación donde todos pierden, el imputado, la sociedad y la víctima. El imputado porque el Estado, asumiendo erróneamente que ha cometido un delito, le impone una pena que no solamente puede implicar la pérdida de su libertad personal (lo que no es poco) sino que además le ocasiona un importante daño social, familiar y económico; la sociedad, porque desde una perspectiva retributiva el daño no sólo no se ha rectificado sino que se ha ampliado, dado que el verdadero autor se mantiene en libertad, además desde la perspectiva de la seguridad ciudadana la condena de un inocente supone - en aquellos casos en que el delito sí existió- la libertad de un culpable que puede reincidir y, por último, porque la condena de un inocente evidentemente deslegitima el sistema penal; y la víctima, porque aunque ella pueda estar segura que quien finalmente se condenó es el culpable, el hecho que no lo sea implica que quien la agredió quedó en la impunidad, lo que podría ser posteriormente descubierto ampliando su dolor.

${ }^{8}$ Piénsese, a modo de ejemplo, en las hipótesis de exclusión de prueba que pueden generarse, por ilicitud en su obtención, a propósito de: la confesión de un imputado (arts. 91, 194 y 195 del CPP); la revisión de las vestimentas, equipajes y vehículos (arts. 85 y 89 del CPP); la entrada y registro, sin autorización judicial o sin las excepciones expresamente previstas, a un lugar cerrado (art. 205 y 206 del CPP); interceptaciones de las comunicaciones fuera de los casos previsto en la ley (art. 222 del CPP y 24 de la Ley 20.000), etc. O bien las limitaciones probatorias que expresamente se regulan para permitir que los 
pudo destruir la presunción de inocencia que los ampara, pero nadie podrá discutir seriamente que los "f inocentes" son distintos a los " $n$ inocentes" y que, por lo mismo, el sistema debe también -como lo hace con estos últimos- tener una preocupación especial por los primeros. Cabe aclarar, en todo caso, que esto no se relaciona en lo absoluto con el hecho que el veredicto del juicio oral deba decir "inocente" o "no culpable", lo cual es absurdo, sino que la importancia de la distinción radica en el enfoque de las preocupaciones epistémicas que deben existir en el proceso y, en particular, en la etapa de investigación (incluida la etapa pre-formalizada).

Para justificar la tesis de que el actual sistema procesal penal chileno es excesivamente vulnerable a las condenas erróneas me valdré de la información que ha surgido del, así llamado, movimiento inocentrista. ${ }^{9}$ Este movimiento, además de encargarse de la litigación de los casos de condenados que reclaman su inocencia, se ha preocupado de investigar las causas de las condenas erróneas y sugerir las modificaciones necesarias para evitar que ellas se produzcan. ${ }^{10}$ De este referente, que hoy se considera uno de los movimientos de protección de derechos civiles más importantes de las últimas décadas ${ }^{11}$

parientes (art. 302 del CPP) u otras personas que, por su estado, profesión o función legal tuvieren el deber de guardar el secreto (art. 302 del CPP), no declaren en el juicio oral. O, también, en aquellas hipótesis que se permite que la autoridad se abstenga de entregar información al Ministerio Público, por considerar que su divulgación pudiera afectar la seguridad nacional (art. 19 del CPP) o aquella que restringe las diligencias de entrada y registro $-\mathrm{y}$ de examen- a lugares donde se puedan encontrar documentos reservados que pudiesen comprometer la seguridad nacional (art. 209 del CPP) o bien porque gozan de inviolabilidad diplomática (art. 210 del CPP).

${ }^{9}$ El término inocentrismo lo popularizó Daniel Medwed en un interesante artículo donde, además de explicar el fenómeno que se ha generado en Estados Unidos a propósito de la exoneración de sujetos erróneamente condenados, explica las distintas críticas y objeciones - de derecha e izquierda- a las que ha sido sometido, y las intenta refutar. Véase, MEDWED, Daniel, "Innocentrism", University of Illinois Law Review, Vol. 2008, pp. 1549-1572, pp. 1549 y ss. Si bien no todos los que participan del movimiento inocentrista postulan una reforma importante del modelo adversarial -sino que sólo establecer más salvaguardas y mecanismos de protección para evitar las condenas erróneas-, lo cierto es que cada vez son más los académicos que, además de reclamar esas medidas, apelan a limitar la adversarialidad y el excesivo rol de las partes en el proceso penal. Esta última línea es la que seguiré en el derrotero del trabajo, sosteniendo que ello es fundamental para alcanzar la verdad del proceso. Por otra parte, el inocentrismo suele asociarse -con una mirada restrictiva del mismo- a un movimiento sólo jurídico que, principalmente, mediante el uso de la tecnología del ADN, ha demostrado que en una cantidad relevante de casos los sistemas penales condenan a imputados " $f$ inocentes", aplicándoles penas privativas de libertad -manteniéndolos varios años presos-o, incluso, imponiéndoles la pena de muerte. Sin duda, y en este último aspecto, la organización que en Estados Unidos más se ha preocupado de la condena de inocentes es el Innocence Project, que al 15 de junio reportaba 292 exonerados. Mayor información en http://www.innocenceproject.org/ [visitado el 15.06.2012]. Sin perjuicio de la extraordinaria relevancia de este tipo de iniciativas, veremos que es mucho más lo que se puede decir respecto del inocentrismo.

${ }^{10}$ En el que hasta ahora se puede considerar uno de los mejores libros de derecho comparado sobre el problema de las condenas erróneas, uno de sus autores, Kathryn Campbell -quien revisa la situación en Canadá-, comienza apelando a la globalidad actual del fenómeno, argumentando que "el concepto de error judicial o de justicia errónea se ha vuelto un fenómeno aceptado en la mayoría de las jurisdicciones occidentales" y entiende que hoy es un imperativo revisar las normas y los procedimientos para mejorar la certeza de las condenas. Este es, creo, el próximo desafío de nuestro modelo procesal penal. Véase CAMPBELL, Kathryn, "The fallibility of justice in Canada, a critical examination of conviction review", en: HUFF, Ronald; KILliAS, Martin (Eds.), Wrongful Conviction, International Perspectives on Miscarriages of Justice, Filadelfia: Temple University Press, 2008, p. 117.

${ }^{11}$ Como dice Medwed, citando una cantidad importante de literatura reciente, el "esfuerzo de liberar a los inocentes se ha transformado en el movimiento de los derechos civiles del siglo XXI. Y, como sucedió con los movimientos de derechos civiles de siglo veinte (raciales, reproductivos, libertad de expresión, etc.) ha impulsado también una preocupación que escapa lo jurídico y ha trascendido a lo social, 
CASTILLO, Ignacio. "Enjuiciando al proceso penal chileno desde el inocentrismo (algunos apuntes sobre la necesidad de tomarse en serio a los inocentes)."

es bastante lo que podemos aprender para analizar críticamente el funcionamiento del proceso penal chileno y sugerir aquello que se debe mejorar. ${ }^{12}$

Digámoslo claro desde el inicio, el sistema adversarial chileno no es, en aquellos casos en que precisamente se espera que lo sea -cuando hay contradictoriedad sobre la veracidad de la afirmación acerca de la existencia de un hecho- confiable y eficiente para prevenir la condena de un imputado "f inocente". Justificar esta tesis es el objetivo del presente artículo. ${ }^{14}$

mediático, cultural, hasta ser parte de la cultura pop". Cfr. MEDWED, "Innocentrism", cit. nota n ${ }^{\circ}$, p. 1550. Destacado en el original.

${ }^{12}$ Como veremos con cierta detención a lo largo del trabajo, parte del inocentrismo ha destacado (junto con los efectos perniciosos del exceso de adversarialidad) siete causas que han sido especialmente relevantes en la condena de imputados "f inocentes", a saber: a) La "visión de túnel" por parte de las policías y los fiscales, que los encierra a perseguir una determinada teoría y les impide abrirse a investigar hipótesis alternativas; $b$ ) errados reconocimientos de testigos oculares o testimonios falsos; $c$ ) falsas confesiones; $d$ ) testimonios de "informantes"; $e$ ) falta de evidencia científica $\mathrm{o}$, en otros casos, exceso de "junk science" (ciencia basura); f) inadecuado manejo y conservación de material biológico con ADN; y, $g$ ) en general, malas conductas de los testigos y de los abogados -incluyendo una deficiente defensa técnica.

${ }^{13}$ Salvo algunas excepciones, en Chile la discusión se ha centrado en lo que uno podría denominar "la cuestión clásica de la epistemología judicial", a saber, los problemas (muy importantes) del valor de la verdad en el juicio oral, de la admisibilidad de la prueba -y su exclusión- en el proceso, la presentación y valoración de la prueba en el juicio oral y, por último, el estándar probatorio que debe existir para dar por probada o no una imputación. En este sentido, véanse a modo de ejemplo los siguientes trabajos, ACCATINO SCAGLIOTTI, Daniela: "El modelo legal de justificación de los enunciados probatorios en las sentencias penales y su control a través del recurso de nulidad", en: ACCATINO SCAGLIOTTI, Daniela (Coord.), Formación y valoración de la prueba en el proceso penal, Santiago: Ed. Abeledo Perrot, 2010, pp. 119 y ss.; ACCATINO SCAGLIOTTI, Daniela, "La fundamentación de la declaración de hechos probados en el nuevo proceso pena. Un diagnóstico", Revista de Derecho de la Universidad Austral de Chile Vol. XIX, No 2 (2006), pp. 9 y ss. BÁEZ, Danilo, “¿Estándar de convicción o arbitrariedad judicial? Bases y propuestas para la interpretación del estándar de "duda razonable" en el Código Procesal Penal”, en: VERDUGO, Mario (Dir.), Gaceta Jurídica, Doctrinas Esenciales, Derecho Penal. T.1, Santiago: Legal Publishing Chile, 2011, pp. 867 y ss.; COLOMA CORREA, Rodrigo, "Panorama General de la Prueba en el Juicio Oral", en: COLOMA CORREA, Rodrigo (Ed.), La Prueba en el Nuevo Proceso Penal Oral, Santiago: Ed. LexisNexis, 2003, p. 27.

${ }^{14}$ Salvo algunos textos que serán citados infra, la dogmática chilena se ha preocupado parcamente de la condena de imputados " $f$ inocentes", tanto de las causas que aumentan el riesgo de condenas injustas, como del sistema previsto legalmente para resolverlo, a saber, el Recurso de Revisión. La Corte Suprema ha tenido una adecuada aproximación restrictiva y de aplicación excepcional del Recurso de Revisión, descartándolo para casos donde no parece ser la condena de un imputado " $f$ inocente" la cuestión central, a saber, cuando el condenado alega la existencia de nuevos antecedentes que justifican una pena alternativa a la pena privativa de libertad (v.gr. Rol N¹729-07), o bien reclama la aparición de nuevos antecedentes que hubieran justificado la apreciación de una circunstancia modificatoria de la responsabilidad penal (v.gr. Rol N40-2011, 1609-07 y 1310-07). En general, sobre la aproximación restrictiva y excepcional con que la Corte Suprema aprecia el recurso véase los fallos Rol N`3337-11 y el voto de minoría en el caso Rol N²227-11.

Sin embargo, la Corte Suprema en ciertas ocasiones ha acogido el Recurso de Revisión, por ejemplo, cuando en la tramitación de la causa se ha condenado a una persona cuya identidad había sido suplantada (v.gr. Rol $\mathrm{N}^{\circ}$ 1498-08 y $\mathrm{N}^{\circ}$ 789-2011) o cuando surgen antecedentes que efectivamente acreditan la inocencia del imputado porque el delito simplemente no se podía configurar (v.gr. Rol No1158-11, la Corte acoge el Recurso de Revisión y anula parcialmente la sentencia condenatoria del recurrente por el delito de porte o tenencia ilegal de arma de fuego, porque se acompaña en el recurso un documento que acreditaba que se había hecho el cambio de domicilio del arma, por lo que su tenencia en ese lugar estaba legalmente justificada). Pero es, por lejos, la resolución del recurso Rol Nº12.018-11 la más impactante, la que debió alertar sobre el funcionamiento del proceso penal y del Recurso de Revisión, para convertirlo 
El modelo chileno adoptó -y se ha consolidado- un sistema adversarial que genera incentivos perversos que facilitan la dictación de condenas erróneas de imputados " $f$ inocentes", me refiero, en particular a la falta de regulación y control (más allá de las cuestiones de garantías) sobre la actividad investigativa que desarrollan las policías y los otros organismos auxiliares, incluso desde antes de la formalización; defensores públicos (en especial los licitados) con alta carga de trabajo que tienen fuertes estímulos para "promover" acuerdos y pocos recursos para generar buenas investigaciones paralelas; una insuficiente e ineficiente forma de evaluar y controlar los antecedentes de la investigación por parte de los jueces de garantía (básicamente a partir de la lectura en audiencia de papeles y documentos - v.gr. partes policiales- donde cada interviniente se esmera por sostener la interpretación que más le conviene) y, por último, la escasa o nula regulación sobre la actividad propia de litigación y de presentación de las pruebas antes y durante el juicio oral. Todo ello sumado al hecho que los jueces adjudicadores cumplen un rol absolutamente pasivo, termina por generar un campo propicio para la condena de imputados "f inocentes".

En definitiva, para dar cuenta de todas estas materias complejas y polémicas me centraré en destacar los ámbitos que hoy incrementan el riesgo de condenar a un inocente, a saber: la visión de túnel; la falta de regulación en ciertas diligencias o evidencias del proceso, como la confesión del imputado, los reconocimientos de los testigos y las víctimas; la calidad y falta de imparcialidad de los peritajes; y la escasa preocupación sobre las entrevistas previas y la preparación de las víctimas, testigos y peritos para el juicio oral. Estos aspectos, que a mi juicio son centrales para alcanzar una sentencia que corresponda con la verdad, se desarrollan en nuestro proceso penal de una manera incompatible con cualquier sistema que pretenda considerarse mínimamente preocupado de no condenar a un inocente.

La invitación del presente trabajo es, como ha sucedido en otros países, a dejar de ver el problema de las condenas erróneas desde una perspectiva centrada en el caso particular o en un actor individual (por qué en ese caso se decidió erróneamente, o fue culpa de tal o cuál interviniente) y comenzar a enfrentarlo como un problema general, un problema del sistema procesal penal. ${ }^{15}$

en una verdadera instancia donde se pueda discutir -sin temor a revisar el juicio oral- la posibilidad de que el sistema hubiese condenado a un imputado " $f$ inocente". En esa causa la Corte decidió acoger un recurso y absolver a Pedro Ariel Lobos Parra, quien había sido condenado a 10 años y un 1 día de presidio mayor en su grado medio, por su participación como autor en tres delitos de robo con intimidación, invalidando con ello una "razonable" sentencia del $5^{\circ}$ Tribunal Oral en lo Penal de Santiago. Respecto del primero de los casos, a saber, cuando se ha condenado a una persona que en realidad no era la que había cometido el delito, la doctrina chilena ha identificado, con bastante razón, que aquella situación no se encuadra dentro de las hipótesis del Recurso de Revisión sino que, en cambio, debiera resolverse por la inexistencia jurídica de la condena, por encontrarse en una hipótesis de error in personam que influye en el adecuado emplazamiento que debe existir en cada proceso. Sobre esto véase, SALAS, Jaime, Problemas del Proceso Penal, investigación, etapa intermedia y procedimientos especiales, Santiago: Librotecnia, 2009, pp. 201 y ss. Dentro de la escaza literatura que se ha hecho cargo en Chile del Recurso de Revisión, véase, FERNANDEZ, José Manuel; OLAVARRÍA, Malva, "Teoría y Práctica de la Acción de Revisión en el Nuevo Código Procesal Penal, Causal Letra d) del Artículo 473”, Ius et Praxis Vol. 2, año 15 (2009), pp. 215-255.

${ }^{15}$ Como dicen Huff y Killias, si uno revisa la experiencia estadounidense, "durante la historia del sistema de justicia criminal la preocupación de los académicos y de los litigantes se centró en la revisión de determinados casos, buscando respuestas individuales. A partir de la década de los ochenta y, principalmente, en los noventa, la cuestión ha girado más bien a un completo análisis del sistema de 
CASTILLO, Ignacio. "Enjuiciando al proceso penal chileno desde el inocentrismo (algunos apuntes sobre la necesidad de tomarse en serio a los inocentes)."

\section{El proceso penal y las causas de las condenas a inocentes.}

En el presente capítulo pretendo identificar, sobre la base de la experiencia del inocentrismo, algunos problemas relativos a la evidencia que pueden estar afectando la capacidad del proceso penal chileno de evitar condenas erróneas, y sugerir cuáles serían las correcciones necesarias que se debiesen adoptar para reducir las condenas a imputados "f inocentes". En definitiva, se trata de establecer mecanismos para mejorar la calidad en el descubrimiento y creación de la prueba, favoreciendo con ello la exigencia de que sea comprensiva, conclusiva y consistente, todo ello para que los jueces consigan, mediante un proceso generalmente inductivo, refutar o corroborar una proposición fáctica imputativa con un alto grado de probabilidad.

La respuesta del inocentrismo a este desafío se ha centrado en la necesidad de regular y controlar la actividad investigativa propia de la etapa de indagación y, en particular, la que desarrollan los órganos vinculados a la persecución penal -y no sólo el Ministerio Público-, a fin de evitar los excesos que suelen producirse, y las distorsiones con que la evidencia se presenta al juicio oral. Para lograr ese objetivo, además del liviano argumento del control horizontal, se requiere que los jueces cautelares y adjudicadores cumplan un rol relevante y ello, como se ha dicho, es imprescindible para alcanzar un resultado ajustado a la verdad. El proceso penal, a diferencia de una investigación científica, opera predominantemente mediante seres humanos: testigos, policías, fiscales, defensores, imputados, víctimas, peritos y jueces. Estos "actores", como lo sugiere Simon, son los que le dan movimiento al sistema penal a través de sus operaciones mentales: percepciones, memoria, reconocimientos, inferencias, prejuicios y decisiones (todas ellas relacionadas con la emoción, estados afectivos, motivaciones, percepciones de roles y metas institucionales). ${ }^{16}$ Ello ocurre desde el inicio de la investigación, desde el mismo momento en que principia a ejecutarse el delito, y desde ahí se van desarrollando, moldeando y adaptando a las distintas necesidades, alternativas, o etapas del proceso. Los actores pueden, por ello, ocasionar un enorme impacto - positivo, pero también negativo- en todo el proceso y, en especial, en el juicio oral.

El rol relevante de los jueces en el control de lo ocurrido en la etapa de investigación se justifica, además, porque la lógica adversarial, como lo ha destacado ampliamente la doctrina comparada, genera incentivos para que en el curso de la investigación y la preparación del juicio oral las partes editen, adornen o derechamente alteren la evidencia. Así, por ejemplo, la experiencia demuestra que la práctica de interrogar privadamente a las víctimas y testigos, primero por la policía y luego por el Ministerio Público -lo que no queda registrado audiovisualmente, sino que únicamente transcribiendo lo que el entrevistador quiere registrar (con la aprobación del declarante mediante la firma, lo que es fácil de obtener si se considera que la víctima y el testigo usualmente quieren colaborar con la persecución)-, y luego el proceso de preparación de los testigos y peritos para el juicio oral, son todos momentos donde los testimonios pueden sufrir graves transformaciones que podrían afectar los elementos centrales de la

justicia criminal adversarial". Sobre esto véase, por todos, HUFF/KILLIAS, Wrongful Conviction, cit. nota $\mathrm{n}^{\circ} 10$, p. 3.

${ }^{16}$ Véase, SIMON, Dan, “The Limited Diagnosticity of Criminal Trials”, Vanderbilt Law Review Vol. № 64 (2011), pp. 143-223, p. 145. 
Polit. crim. Vol. 8, No 15 (Julio 2013), Art. 7, pp. 249 - 313.

[http://www.politicacriminal.cl/Vol_08/n_15/Vol8N15A6.pdf]

evidencia. ${ }^{17}$ Por ello, se suele usar la expresión evidencia sintetizada en oposición a evidencia completa, donde la última ha sufrido algún grado de alteración, ya sea por el propio interés del testigo, o por incentivos de las partes en el proceso adversarial. ${ }^{18}$ Confiar en que los jueces sean capaces -sin mayores herramientas, actuando como espectadores que esperan que el contradictor evidencie la mentira o la omisión en el contrainterrogatorio- de descubrir el delta entre la evidencia sintetizada y la completa es irreal. Se requiere, como lo veremos infra, de jueces con más facultades y con mayores herramientas.

Con todo, la necesidad de regular y controlar intensamente la etapa de investigación, como un adecuado mecanismo profiláctico (también de carácter cognoscitivo) para evitar condenas erróneas, ha sido subrayado con especial atención en el derecho comparado. Así, a modo de ejemplo, en el año 2002, la Sección de Justicia Criminal del ABA, estableció un Comité Ad Hoc para asegurar la integridad del proceso criminal, en particular durante la indagación. Después de tres años de trabajo el comité redactó una resolución y acompañó diversos reportes, todos los cuales fueron luego aprobados por la House of Delegates del ABA. La resolución acordaba nueve aspectos centrales, a saber:

1. Falsas Confesiones.

2. Identificación de testigos oculares.

3. Evidencia Forense.

4. Informantes, en especial los privados de libertad.

5. Prácticas de abogados defensores.

6. Investigaciones policiales.

7. Prácticas de Fiscales.

8. Remedios Sistémicos.

9. Compensación para los condenados erróneamente.

En este trabajo se revisarán aquellos aspectos de mayor relevancia en Chile, y que considero constituyen espacios evidentes de vulnerabilidad de nuestro sistema, pues generan un claro riesgo de condenas de imputados "f inocentes" por sus implicancias en la etapa de investigación y de adjudicación. Me refiero a las cuestiones indicadas en los $\mathrm{N}^{\circ}$ 1, 2, 3, 4, 6 y 7 de la lista supra citada. El lector rápidamente observará que, lamentablemente, aquellas materias que recién se indicaron tienen en nuestro CPP una escasa o nula regulación.

En todo caso, para que el recorrido de esta sección del trabajo tenga sentido, es importante y necesario que el lector se abra a reconocer los defectos y las falencias del proceso de investigación adversarial, pues, como dice Jackson, estos defectos y falencias aumentan -y sus resultados pueden ser fatales- en los procesos de identificación e interrogación a imputados, en el levantamiento de la información

\footnotetext{
${ }^{17}$ En el estado actual del desarrollo de la tecnología (para las notificaciones o los registros) no parecen existir buenas razones para que el Ministerio Público no deba, primero, convocar a la defensa a las diligencias de "toma de declaraciones" de testigos o víctimas que sean relevantes en una determinada causa; o, segundo, registrarlas en video o audio para que la defensa tenga un conocimiento integro -y no limitado al registro formal del documento- de la declaración. En el caso de las policías, la primera hipótesis es más compleja, pero la segunda, en cambio, se puede alcanzar tan sólo con una grabación de audio, y ello no parece difícil de realizar. Ello, como se ha destacado, mejoraría en transparencia y completitud la exigencia de registro consagrada en los arts. 227 y 228 del CPP.

${ }^{18}$ En el mismo sentido, véase, SIMON, “The Limited Diagnosticity”, cit. nota n 16, p. 151.
} 
CASTILLO, Ignacio. "Enjuiciando al proceso penal chileno desde el inocentrismo (algunos apuntes sobre la necesidad de tomarse en serio a los inocentes)."

relevante para el caso (v.gr. declaraciones de víctimas y testigos) pero, por sobre todo, porque el modelo adversarial, durante la investigación, tiene fuertes incentivos para ir polarizando a las partes y generando un sesgo en la persecución penal y en los testimonios. $^{19}$

En ese contexto, por ejemplo, me parece necesario reconocer que el actual sistema procesal penal justamente no cumple (salvo en casos muy especiales, con defensas de alto nivel e importantes recursos) la utopía del modelo adversarial de igualdad y contradictoriedad de las partes, que idealmente aspira a permitir que se descubra y se realice un test a toda la información posible. Por el contrario, hoy día las policías, o los fiscales con la colaboración de la policía, tienen el monopolio -diría bastante descontrolado y desregulado, sobre todo en la etapa preformalizada- de la información existente y recopilada, que en general se mantiene ignorada hasta la decisión de formalizar. $\mathrm{Y}$ en esos casos la información que llega a la contraparte no es toda la existente, sino que la que una parte quiere que la otra conozca. ${ }^{20}$

Esto es similar con lo que sucede con el mito de la "bilateralidad" respecto de la recolección de la evidencia, que pareciera adscribir nuestro modelo procesal penal. El CPP asume que la defensa no solamente debería presentar su evidencia en el juicio, sino que la debe buscar y encontrar antes, dado que el proceso descansa sobre el supuesto que los adversarios van a ser igualmente estrictos en sus habilidades para obtener y presentar evidencias para apoyar su teoría del caso. Pero eso no es así, la defensa pública no tiene recursos humanos y materiales suficientes para generar una compleja investigación autónoma y, en general, va al juicio a realizar una defensa pasiva -con un excesivo abuso de la teoría que se resume en "el Ministerio Público no podrá acreditar más allá de toda duda razonable..." o "en este caso hay una evidente falta de evidencia probatoria que impedirá alcanzar el estándar exigido por nuestro legislador, el de más

19 Véase, JACKSON, John, "Theories of Truth Finding in Criminal Procedure: An Evolutionary Approach", Cardozo Law Review Vol. N 10 (1988-1989), pp. 478 y ss.

${ }^{20}$ No se trata, por cierto, de que deliberadamente se oculten documentos o que se arme una "carpeta de investigación paralela" (que si en algún caso sucediera sería francamente inaceptable), sino que a una cuestión mucho menos consciente pero igualmente dañina, a saber, el monopolio de las policías en el registro de las primeras actuaciones y cómo ello condiciona el debate que después se realiza -v.gr. ante el juez de garantía - a partir de la lectura de esos registros y sin posibilidad de poder contar con la fuente presencial. Lo importante es que a pesar de la obligación de registro, a que hacen referencia los artículos 227 y 228 del CPP, lo cierto es que el modelo de investigación (unilateral e interesado) incentiva únicamente el registro de las diligencias favorables de la actividad policial a la pretensión de la persecución. Ejemplificando: cuando un fiscal recibe la carpeta de investigación físcal para la realización de una audiencia de control de detención, seguramente no ha tenido tiempo de revisarla previamente con detención ni tampoco de dirigir la actividad investigativa de la policía. La policía, a su vez, confecciona el parte policial de una manera absolutamente parcial, centrando la redacción y las evidencias en aquello que incrimina al imputado, entonces, luego ni el fiscal ni menos el defensor pueden saber qué exactamente ocurrió. Menos el Juez. Y, así y todo, se toman decisiones como la prisión preventiva. La alternativa, se podría argumentar, es que el imputado declare, lo cual es un incentivo perverso para hacerlo renunciar a su derecho a guardar silencio. En cambio, como sucede en otros países, lo razonable sería que frente a ciertas dudas respecto de los registros o por la complejidad del caso, los propios policías que participaron de la detención concurran a la audiencia de control de detención y sean sometidos al contradictorio. Lo mismo con algunos testigos claves, en casos en que así lo considere el juez, de oficio, o a petición de una de las partes. Ello permitiría un nivel de debate mucho mejor, una mayor calidad en los antecedentes a partir de los cuales se decretan medidas privativas de libertad tan intensas como la prisión preventiva, una mayor protección de derechos fundamentales y de garantías, pero también un elevado mérito epistémico en las decisiones judiciales. 
Polit. crim. Vol. 8, No 15 (Julio 2013), Art. 7, pp. 249 - 313.

[http://www.politicacriminal.cl/Vol_08/n_15/Vol8N15A6.pdf]

allá de toda duda razonable". Y, aunque los tuviera, difícilmente podría contrarrestar el enorme poder y ventaja que tiene la persecución que, como sabemos, tiene acceso privilegiado - porque es aquella que recibe la notitia criminis- a los testigos, la evidencia material y, en fin, a toda la escena del delito. En resumen, el desbalance del sistema adversarial actual es innegable y por lo mismo el control de los jueces, cautelares y de adjudicación, es fundamental.

\subsection{La Visión de Túnel y la Adversarialidad.}

Antes de entrar a las cuestiones específicas que afectan la calidad de la información que los tribunales reciben conviene, primero, revisar -aunque sea someramente- un problema transversal que, según lo ha demostrado la literatura comparada vinculada al inocentrismo, afecta de manera relevante el mérito y la veracidad de la información del proceso penal. Me refiero, en particular, a la llamada visión de túnel.

La visión de túnel puede ser definida, siguiendo a Findley y Scott, como un conjunto de modelos deficientes de investigación y de falacias lógicas, que son susceptibles de producirse en todas las investigaciones, y que inducen a los intervinientes del sistema de justicia penal a "focalizarse en un sospechoso; seleccionar y filtrar la evidencia que les permite 'armar el caso' para lograr una condena, mientras ignoran o suprimen evidencia que permitiría excluir la culpabilidad". ${ }^{21}$ El Report on the Prevention of Miscarriages of Justice de Canadá, en todo caso, lo definió como

"una obstinada y estrecha focalización en una particular línea de investigación o en una sola teoría de la persecución, suficientes para irrazonablemente colorear la evaluación de la información recibida y determinar la propia conducta, en respuesta a esta información". ${ }^{22}$

Es importante destacar que la visión de túnel, como lo identificó el informe recién mencionado, generalmente va asociada a una especie de "causa noble de corrupción", a saber, la noción que el fin justifica los medios, lo que en términos prácticos se traduce en que como la policía o el fiscal están seguros que el imputado cometió el delito, para ellos realizar algunas prácticas inadecuadas se justifica como necesario para asegurar la condena. $^{23}$

\footnotetext{
${ }^{21}$ FINDLEY, Keith; SCOTT, Michael, "The Multiple Dimensions of Tunnel Vision in Criminal Cases", Wisconsin Law Review Vol. 2006, pp. 291-397, p. 292.

${ }^{22}$ Véase, Report on the Prevention of Miscarriages of Justice, preparado por la Canadian FederalProvincial-Territorial Heads of Prosecutions Committe, pp. 35 y ss., texto que puede descargarse en http://www.justice.gc.ca/eng/dept-min/pub/pmj-pej/pmj-pej.pdf [visitado el 10.09.2012].

${ }^{23}$ Seguramente Haack no estaba pensando precisamente en esto, pero existe una frase en su texto Epistemology Legalized, que bien vale la pena citar en este punto, porque da cuenta de la tensión entre investigaciones serias (científicas), y aquellas sesgadas por una visión de túnel. Haack sostiene que "las investigaciones se conducen mejor mientras más perceptiva, imaginativa e informadas sean las conjeturas, mientras más riguroso sea el razonamiento, mientras más completa sea la búsqueda de la evidencia, y mientras más escrupulosamente honesto y juicioso sea el proceso de valoración de la prueba. Hablando estrictamente, de hecho, si estás tratando de encontrar evidencia que apoye una conclusión previsible, en vez de seguir la evidencia donde ésta te lleve, no estás de verdad investigando". Véase HAACK, Susan, "Epistemology Legalized: or, truth, justice, and the american way", p. 7, descargable en http://www.as.miami.edu/phi/haack/EPISTLEG.pdf [visitado el 22.10.2012].
} 
CASTILLO, Ignacio. "Enjuiciando al proceso penal chileno desde el inocentrismo (algunos apuntes sobre la necesidad de tomarse en serio a los inocentes)."

Es, entonces, una deficiencia que suele afectar principalmente a la policía y a la fiscalía, pero que también en ocasiones alcanza a la defensa, jueces y a todos los intervinientes del sistema penal. De hecho, la experiencia comparada demuestra que en la mayoría de los casos de visión de túnel, ella comienza con la policía y luego es traspasada al fiscal, lo que es suficiente para afectar a todo el proceso y a todos los participantes, incluyendo defensa, jueces, testigos y peritos: porque el resto de los actores tienen una limitada capacidad para neutralizarla, v.gr. la defensa pública, con su escasa capacidad de investigar, difícilmente puede hacerlo, y los jueces, sobre todo si están sentados pasivamente en el juicio oral, menos. Si bien la literatura comparada reconoce que la visión de túnel es una cuestión básicamente "humana", de ello no se deriva que no nos debemos preocupar de su existencia o que debamos confiar en un principio abstracto y deficientemente regulado como el principio de objetividad, por el contrario, debemos generar procedimientos para prevenirla, detectarla y corregirla. ${ }^{24}$ De hecho, desde el punto de vista estadístico, los estudios ligados al inocentrismo detectaron que la visión de túnel se presentó en todos los casos investigados de condenas de imputados " $f$ inocentes". ${ }^{25}$

Ahora bien, la visión de túnel, según como ha sido explicada por los sicólogos, puede también ser entendida como parte de distintos "prejuicios cognitivos" que van afectando y dañando la persecución penal. Así, textualmente Findley et al consideran que los prejuicios más importantes en este aspecto son:

1. Prejuicio de confirmación. Es la tendencia a buscar o interpretar evidencias en el sentido que sostengan las creencias, las expectativas o las hipótesis preexistentes. Cuando se testea una hipótesis o una conclusión, las personas tienden a buscar información que confirme sus primeras hipótesis y a evitar aquellas que puedan refutarlas. La gente no sólo busca información prejuiciosamente, sino que también tiende a recordar información de una

\footnotetext{
${ }^{24}$ En el trabajo decidí intencionalmente dejar fuera la cuestión relativa al principio de objetividad del Ministerio Público, porque creo que ello debe ser tratado en un artículo independiente. Esta institución que, como sabemos, está regulada en la Constitución (art. 83 CPR), la Ley Orgánica Constitucional del Ministerio Público (art. 1 y 3 LOCMP) y en el CPP (art. 3 y 77 CPP), es de absoluta trascendencia y, lamentablemente, en Chile ha sido escaza y -a veces- equivocadamente explicada, renunciando a darle un contenido fuerte para no afectar la adversarialidad. El error de ello es evidente, porque la visión de túnel, sumado a una errada concepción del principio de objetividad, constituye una combinación explosiva para que se produzcan condenas de imputado " $f$ inocentes". Lo preocupante de ello es que esto ya se ha empezado a observar. En este sentido, véase el interesante estudio de García, quien, a propósito del capítulo "proposición de diligencias", señala que cerca de un 50\% de los entrevistados indicó desconocer cuales criterios, directrices o reglas tenían los fiscales para rechazar las solicitudes de diligencia de los defensores -lo que refleja una amplia discrecionalidad, que se suma al hecho inexplicable que muchas veces ni se justifican los rechazos a las solicitudes- pero, lo más lamentable de todo, es que la gran mayoría de las veces los fiscales son reticentes a aceptar cualquier diligencia que perjudique su teoría del caso. Véase, GARCIA, Ramón, "El Ejercicio del Derecho a Defensa Técnica en la Etapa Preliminar del Proceso Penal", en: FUENTES, Claudio (Coord.), Diez años de la reforma procesal penal en Chile, Santiago: Ediciones Universidad Diego Portales, 2011, pp. 268 y ss. A pesar del carácter exploratorio que el autor le asigna a su trabajo, no puede dejar de reconocerse que éste es uno de los estudios más relevantes del último tiempo, relativo a la reforma. No por lo extenso, ni tampoco por la profundidad del mismo, sino que porque sale de los típicos estudios "de rendimiento y eficiencia", para abrir el debate sobre aspectos críticos de la reforma.

${ }^{25}$ Véase, MARTIN, Dianne, "Lessons About Justice from the 'Laboratory' of Wrongful Convictions: Tunnel Vision, the Construction of Guilt and Informer Evidence”, UMKC Law Review Vol. N 70 (2002), pp. 847-864, p. 848 .
} 
Polit. crim. Vol. 8, No 15 (Julio 2013), Art. 7, pp. 249 - 313.

[http://www.politicacriminal.cl/Vol_08/n_15/Vol8N15A6.pdf]

manera prejuiciosa. Las personas generalmente requieren, para aceptar una hipótesis, menos evidencias consistentes con aquella ya generada $\mathrm{y}$, a su vez, requieren de más evidencias inconsistentes con la hipótesis, para rechazarla.

2. Prejuicio retrospectivo. Generalmente opera como una forma a través de la cual las personas proyectan nuevos conocimientos -resultados- con el pasado, sin ningún cuidado con que la percepción del pasado haya sido teñida por la información subsecuente. El prejuicio retrospectivo es producto del hecho que la memoria es un proceso dinámico de reconstrucción. Este prejuicio puede reforzar prematuramente la incriminación respecto de una persona $o$, descuidadamente, focalizarla en un sospechoso aunque sea inocente.

3. Prejuicio en el Resultado. Abarca todo proceso en que las personas proyectan nuevos conocimientos - resultados- en el pasado sin ninguna preocupación que la información del conocimiento adquirido influya en su percepción del pasado. Se diferencia de la anterior en que ésta no se refiere a los efectos de la información resultante en la probabilidad esperada del resultado, sino que en sus efectos en la evaluación de decisiones de calidad hacia el futuro. ${ }^{26}$

En resumen, la visión de túnel se produce cuando la policía y el Ministerio Público focalizan la persecución penal en uno o más individuos, y ello los hace actuar convencidos de la culpabilidad del imputado, a pesar de la nula o escasa evidencia que exista en su contra. Esa actitud, como lo demuestra la experiencia comparada, lleva a omitir la búsqueda o el registro de evidencia exculpatoria y, por el contario, incentiva únicamente la búsqueda y el registro de evidencia confirmatoria; muchas veces incrementando el valor específico de algunas de ellas, manipulándolas para darle una mayor consistencia a su propia teoría del caso o bien derechamente plantando evidencia. En muchos casos la visión de túnel se inicia impulsada por el prejuicio anterior de la policía con un presunto autor (un imputado conocido, alguien problemático dentro del sector de vigilancia, un drogadicto, etc.) o bien respecto de una persona que, lamentablemente, tuvo el infortunio de estar en el momento inadecuado en el lugar incorrecto. ${ }^{27}$

Como se comprenderá, así además lo han explicitado los estudios empíricos, esta forma de confirmar un juicio anticipado de culpabilidad impacta negativamente no sólo en la identificación e imputación inicial de una persona, sino que también en las entrevistas a los testigos, víctimas e, incluso, en los interrogatorios y reconocimientos de los sospechosos, además en la redacción y entrega de la información a las otras partes, etc.

Lo complejo respecto de la visión de túnel -y que aconseja asumirla más en serio de lo que en Chile se ha hecho- es que a menudo es también el producto de presiones institucionales y culturales, más que de la mala fe o indiferencia de un particular interviniente. ${ }^{28}$ En este sentido, son varios los autores que afirman que la visión de túnel se ve reforzada por el sistema adversarial, que genera presiones sistémicas e

\footnotetext{
${ }^{26}$ Las tres categorías, profundamente explicadas, en FINDLEY; SCOTT, “The Multiple Dimensions”, cit. nota $\mathrm{n}^{\circ} 21$, pp. 300 y ss.

${ }^{27}$ Véase, FINDLEY; SCOTT, “The Multiple Dimensions”, cit. nota n² 21, pp. 292 y ss.

${ }^{28}$ Véase, FINDLEY; SCOTT, “The Multiple Dimensions”, cit. nota ${ }^{\circ} 21$, p. 292. El mismo Report on the Prevention of Miscarriages of Justice de Canadá, cit. nota $\mathrm{n}^{\circ} 22$, pp. 35 y ss., consideró especialmente este tipo de presiones, que crean una atmósfera que incentiva a las autoridades a buscar condenar a una persona, a pesar de la existencia de evidencias ambiguas o contradictorias.
} 
CASTILLO, Ignacio. "Enjuiciando al proceso penal chileno desde el inocentrismo (algunos apuntes sobre la necesidad de tomarse en serio a los inocentes)."

institucionales para que las policías y el Ministerio Público resuelvan de un modo rápido y con información eminentemente acusatoria la responsabilidad del autor. Pero además, este fenómeno tiene especial importancia en casos donde existe presión política y pública; o sea, crímenes de evidente interés y conmoción social, donde surge una presión para que se detenga y sancione rápidamente a él o los responsables. ${ }^{29}$

Así, en el caso de las policías y el Ministerio Público las presiones institucionales más recurrentes son:

1. Para terminar luego el caso.

2. Cuando necesitan encontrar a un culpable.

3. Cuando quieren dar un mensaje de confianza a las autoridades y a la ciudadanía.

4. Los movimientos pro-víctima también pueden generar una visión de túnel.

5. La carga de trabajo de las policías y fiscales. ${ }^{30}$

Por todo lo anterior, debe ponerse especial atención -y controlar seriamente- la visión de túnel que se produce en las policías y el Ministerio Público en los momentos tempranos de la investigación. Ello, lamentablemente, no sucede en Chile. Por el contrario, las policías actúan, en una buena medida, con bastante libertad y sin claros procedimientos, protocolos o directrices, lo que facilita que -consciente $\mathrm{o}$ inconscientemente- lo hagan enceguecidas por la visión de túnel. Lo anterior se agrava porque no existen medios institucionales ni facultades legales específicas, ni en el Ministerio Público ni en los jueces, para prevenir y limitar este tipo de conductas. ${ }^{31}$

Por lo mismo, se debería proponer, como de hecho se está realizando en Inglaterra, que en los casos complejos un oficial de la policía - externo a la investigación- sea el encargado de asumir como compliance officer, responsable que la policía dé cabal cumplimiento a la normativa vigente, asegurando que se investiguen también las hipótesis de inocencia del imputado, preocupándose que se registre adecuadamente toda la información exculpatoria e inculpatoria pero, principalmente, cerciorándose que se le entreguen al Ministerio Público todos los antecedentes relevantes del caso. Este funcionario policial sería el responsable, internamente, de que las policías cumplan con rigurosidad la legislación vigente que regula su función, pero también externamente, con el Ministerio Público y el resto de los intervinientes, en el sentido de ser la garantía que no se están violando ciertos derechos de los imputados (v. gr. derecho a defensa) ni tampoco que se afecta la calidad epistémica del proceso (con distorsiones u omisiones de información de suficiente mérito para afectar la veracidad de la imputación).

\footnotetext{
${ }^{29}$ Aunque no tiene directa relación con la visión de túnel, en muchas investigaciones donde aquella existe se da también un fenómeno de demonizar públicamente a los imputados, expresándose hacia ellos como "antisociales", "peligrosos", "terroristas", "anarquistas", o de otra forma que los identifique como enemigos de la sociedad.

${ }^{30}$ Véase, FINDLEY; SCOTT, “The Multiple Dimensions”, cit. nota n² 21, pp. 292 y ss.

31 Véase, RISINGER, Michael; RISINGER, Lesley, "Innocence is Different: Taking Innocence into Account in Reforming Criminal Procedure", p. 8, descargable en http://ssrn.com/abstract=1783941. Si a eso se le agrega la innegable injerencia, en nuestro país, desde el ámbito político hacia las policías, a fin de que ellas muestren mayor eficiencia y celeridad en la resolución de los casos, el incentivo para una persecución arbitraria y dirigida se incrementa fuertemente. Y lo preocupante es que esa injerencia se produce tanto respecto de la generalidad de los casos y, con mayor visibilidad, en aquellos que generan conmoción pública.
} 
Por otra parte, es importante destacar que el Ministerio Público tiene una función trascendental en relación a la visión de túnel, pues debe ser capaz, sin excusas, de exigir que las policías sean honestas y leales en el registro y en la comunicación de la información recopilada, desde la elaboración del parte policial y durante toda la investigación. ${ }^{32}$ Sin embargo, el modelo adversarial nuevamente dificulta esa meta porque, como lo destaca el profesor Mitchell, la adversarialidad comienza desde el inicio "una vez producido el arresto, identificado el sospechoso principal, la policía abdica de su rol de investigador neutral y comienza a ser abogado [parte del equipo] de los fiscales". ${ }^{33}$ En nuestro caso ello se agrava por la opción institucional de poner a las policías como organismos auxiliares del Ministerio Público. En definitiva, el sistema genera un interés compartido entre las policías y el Ministerio Público, a saber, considerar que el detenido es el culpable y que debe ser condenado. ${ }^{34}$

Dicho de otra manera, el diseño institucional del proceso penal chileno, en el cual se ubicó a las policías como "organismos auxiliares" del Ministerio Público, genera un incentivo difícilmente controlable (y evitable) de que las policías se sientan parte de la persecución. Ellas difícilmente pueden actuar de manera imparcial, objetiva y neutral, pues se sienten integrantes del equipo del Ministerio Público (un actor relevante y estratégico de esta cultura de justicia de partes propia del sistema adversarial) y, por lo mismo, actúan principalmente con el objetivo de asegurar la condena. ${ }^{35}$

\footnotetext{
${ }^{32}$ Así, por lo demás, lo prescribe el artículo 80 del CPP que expresamente indica que "Los funcionarios señalados en el artículo anterior [policías y gendarmes] que, en cada caso, cumplieren funciones previstas en este Código, ejecutarán sus tareas bajo la dirección y responsabilidad de los fiscales y de acuerdo a las instrucciones que éstos les impartieren para los efectos de la investigación (...)”.

33 Véase, MITCHELL, John, "The Ethics of the Criminal Defense Attorney-New Answers to Old Questions", cit. por Stanley FISHER en: “Just the Facts, Ma'am': Lying and the Omission of Exculpatory Evidence in Police Reports", New England Law Review Vol. N 28 (1993), pp. 1-62, p. 57. Mitchell utiliza la expresión "lawyers" al referirse a los policías, con lo que quiere decir que ellas pasan a ser "abogados" del equipo de los fiscales; ciertamente eso en nuestra realidad parecería un exceso. Lo importante, como lo destaca Fisher, es que Mitchell identifica correctamente la etapa en la que la policía adquiere un interés positivo en terminar rápidamente el caso y un interés negativo en entregar evidencia que pueda evitar una condena.

${ }^{34}$ Como se sabe, el artículo 79 del CPP prescribe que las policías (Carabineros de Chile y la PDI) son organismos auxiliares del Ministerio Público y, por lo mismo, deben ejecutar las tareas de investigación conforme lo instruyan los fiscales. Además, y lo que resulta particularmente grave, la misma norma dispone que Gendarmería de Chile -un organismo penitenciario que carece absolutamente de la competencia para realizar investigaciones profesionales, respetuosa de los derechos fundamentalespuede también adquirir esa calidad en las investigaciones de hechos constitutivos de delitos al interior de las unidades penitenciarias. Como es fácil de advertir, si el problema de la visión de túnel resulta difícil de enfrentar en las unidades policiales (que se supone son profesionales al investigar), en el caso de Gendarmería - donde además se debe agregar la cultura carcelaria, en sí misma prejuiciosa- lo anterior resulta casi imposible.

${ }^{35}$ Véase, GARCÍA, Ramón, "El ejercicio del Derecho a defensa técnica en la etapa preliminar", en: FUENTES, Diez años de la reforma, cit. nota ${ }^{\circ} 24$, p. 241 y ss. Considérese, en especial, lo referente a la relación con la policía en la etapa de investigación (4.5). Ahí se menciona lo siguiente: "Finalmente, interrogados los defensores sobre los principales problemas con la policía, las respuestas fueron varias, siendo las más recurrentes aquellas relacionadas con cierta forma de desconfianza en la labor de la defensa. Así un defensor manifestó que los policías 'ven la figura del defensor como un enemigo, a pesar de un discurso en contrario, en la práctica, es decir, en el día a día, tratan de no entregar mucha información al defensor/a'. Otros remarcaron como problema la 'eficiencia y rol' de la policía." El problema, como lo he dicho, no es la eficiencia y el rol, el problema es la adversarialidad. Al menos el diseño institucional de la adversarialidad impuesto en Chile.
} 
CASTILLO, Ignacio. "Enjuiciando al proceso penal chileno desde el inocentrismo (algunos apuntes sobre la necesidad de tomarse en serio a los inocentes)."

A pesar de lo anterior, o precisamente por lo anterior, las policías y los fiscales deberían ser entrenados para investigar de manera neutral teorías alternativas, al menos hasta que esté razonablemente claro que otras teorías no tienen merito. ${ }^{36}$ Junto a ello, se debería generar un procedimiento de escrutinio más fuerte para los casos débiles. La misma comisión de la NYSBA respecto de la visión de túnel propuso que se realicen protocolos de investigación, sumado a un checklist de cumplimiento de las obligaciones policiales, ${ }^{37}$ lo que parece ser sólo medidas mínimas, pero necesarias para evitar este tipo de fenómenos en la investigación.

Por último, para limitar y controlar la visión de túnel de las policías y el Ministerio Público se debería proponer que, junto con reforzar el control horizontal por parte de la defensa -que en todo caso los estudios comparados han sugerido como algo bastante ineficiente-, exista un mayor control de los jueces. Ese control debería ser de dos vías. El primero lo deberían realizar los jueces de garantía, quienes debiesen tener una mayor injerencia en la revisión de las diligencias y las evidencias de un determinado caso, principalmente asegurando que se respeten los criterios y estándares para cautelar además del respeto de las garantías fundamentales- el peso epistémico de la evidencia, garantizando una investigación que se oriente a la averiguación de la verdad. En este punto, por ejemplo, los jueces de garantía deberían ejercer un estricto control, v. gr. al decretar las medidas cautelares, sobre la forma exacta en que se desarrollaron las diligencias y, por qué no, en algunas de ellas que sean claves incluso debieran participar. Así, por ejemplo, no veo buenas razones para criticar que un juez de garantía -asumiendo una posición de observador, garante de la legalidad y de la corrección de la diligencia, y no de inquisidor a cargo de la misma- pueda participar de ciertas actividades trascendentales, como un reconocimiento en rueda de imputados, o pueda exigir la comparecencia a una audiencia de un policía o un testigo para que sea sometido al debate contradictorio (o a sus propias preguntas) como insumo para poder resolver o, incluso, que a petición de parte o de oficio pueda ordenar la realización de una pericia que pueda servir en el proceso de adjudicación. La participación del juez como observador podría asegurar un mejor control y calidad de la información.

El segundo control, tan relevante como el primero, lo deberían desarrollar los jueces que ejercen una función adjudicativa, quienes debiesen ser especialmente estrictos en términos de asegurar que la evidencia que se les presenta sea la adecuada (de calidad) para determinar la veracidad, con un alto grado de probabilidad, del enunciado que afirma la existencia de un determinado hecho jurídico penalmente relevante. En ciertos casos esto último supone, sobre todo, revisar estrictamente el proceso a través del cual se obtuvo esa evidencia durante la etapa de investigación, para determinar si ello supera el cedazo de la lógica y los conocimientos científicamente afianzados. Es cierto que hoy los jueces adjudicadores no tienen mayores facultades para lograr esto, y que ello debería ser una cuestión de lege ferenda, pero igualmente el estándar de convicción y la facultad de realizar preguntas (con una interpretación más extensiva) serían buenas herramientas para, como lo veremos infra, controlar este fenómeno.

\footnotetext{
${ }^{36}$ Reporte de la Comisión de la New York State Bar Association del 2008, p. 44 . El informe puede descargarse en

http://www.nysba.org/Content/ContentFolders/TaskForceonWrongfulConvictions/FinalWrongfulConvicti onsReport.pdf [visitado 13.09.2012]

${ }^{37}$ Reporte de la Comisión de la NYSBA, cit. nota ${ }^{\circ}$ 36, p. 45.
} 
Polit. crim. Vol. 8, No 15 (Julio 2013), Art. 7, pp. 249 - 313.

[http://www.politicacriminal.cl/Vol_08/n_15/Vol8N15A6.pdf]

Veamos ahora algunos de los aspectos específicos, ya anunciados, que han sido identificados por el movimiento inocentrista como de mayor incidencia en las condenas de imputados "f inocentes", y cómo ellos están regulados y tratados en nuestro país.

\subsection{Falsas Confesiones.}

Como dice White, el movimiento del inocentrismo ha logrado reinstalar una cuestión que parecía reservada a la época de la inquisición, a saber, que las confesiones falsas existen. Que hay imputados que, por diversas razones, confiesan delitos que no cometieron. ${ }^{38} \mathrm{El}$ inocentrismo también ha evidenciado que las confesiones falsas tienen, además de un serio problema de garantía y respeto a los derechos fundamentales, un grave inconveniente desde la perspectiva de su mérito epistémico que impacta profundamente en una inadecuada decisión del tribunal. Por último, que el modelo adversarial es en este punto deficiente, porque centra su preocupación y sus propuestas profilácticas básicamente en aspectos de garantías, pero no así en los epistémicos. Por todo ello, parte del inocentrismo ha sostenido la necesidad de generar mecanismos de protección de las confesiones -no sólo pensados desde el procedural justice- sino que derechamente sobre su calidad como evidencia para evitar condenas a imputados " $f$ inocentes".

La respuesta más común del por qué de las confesiones falsas es que ello suele ser el fruto de la tortura, de un acto de coacción de la policía o de un tratamiento cruel que generó en el imputado la "necesidad" de confesar un delito que en realidad no cometió o que no existió. Eso puede ser así en algunas oportunidades pero, en todo caso, ello sucede -como lo han demostrado las investigaciones empíricas- excepcionalmente. En cambio, la literatura del inocentrismo ha identificado como un factor central en las confesiones falsas de los imputados "f inocente" algo que en Chile ha pasado casi inadvertido, a saber, la precisa técnica de interrogatorio con la cual las policías desarrollan esta diligencia. De hecho, de lo indagado en la literatura chilena, ni siquiera es posible saber cuál es la técnica de interrogatorio que se les enseña a las policías y que hoy utilizan.

Porque interrogar no es simplemente sentarse a conversar con un sospechoso e intentar disuadirlo de que colabore con la investigación; tampoco es jugar al "bueno y el malo" esperando que el malo logre generar un temor en el sospechoso y el bueno ganar su confianza para que confiese; ni menos de algún conocido mecanismo de tortura

\footnotetext{
${ }^{38}$ De hecho, según el Innocence Project, cerca de un cuarto de los casos de condenas erróneas en Estados Unidos incluyeron confesiones que luego se demostraron falsas. Innocence Project, False Confessions, revisable en http://www.innocenceproject.orglunderstand/False-Confessions.php [visitado el 19.09.2012). Lo interesante de esto es que suele considerarse el fenómeno de las confesiones falsas como particular de la cultura inquisitiva. De hecho, como lo explica White, en el modelo adversarial "la idea que un sospechoso, que no tenga perturbaciones mentales o sea víctima de una coerción física, pueda confesar un crimen que no cometió parece contraintuitivo. Incluso en 1940, cuando los métodos de interrogación policial eran menos humanos que lo que son hoy, el gran profesor, John Henry Wigmore, sostenía que las falsas confesiones eran raras. Más de un siglo después, Joseph Buckley, el coautor de uno de los manuales de interrogación más ampliamente usados, analizando las actuales técnicas de interrogación concluyó que, cuando eran usadas apropiadamente, estas técnicas no producirían falsas confesiones". Véase, WHITE, Welsh, "False Confessions and the Constitution: Safeguards Against Untrustworthy Confessions", Harvard Civil Rights-Civil Liberties Law Review Vol. N 32 (1997), pp. 105-157, p. 108. Todo esto, a la luz de la información del inocentrismo, ha sido fuertemente cuestionado.
} 
CASTILLO, Ignacio. "Enjuiciando al proceso penal chileno desde el inocentrismo (algunos apuntes sobre la necesidad de tomarse en serio a los inocentes)."

utilizando agua, música estridente o evitando que el imputado duerma. Interrogar es bastante más complejo que eso. De hecho existen varios métodos de interrogatorio, cada uno de ellos tiene sus propias técnicas y habilidades, que desde luego se aprenden y se aplican a los imputados. Y, al menos que creamos que en Chile las policías no usan ninguno, y que lo hacen intuitivamente -lo cual hablaría muy mal de su proceso de formación-, lo relevante sería preocuparnos de averiguar cuál es y qué protocolos existen para su correcta ejecución.

En Estados Unidos, y en muchos otros países (quizás uno podría pensar que también en Chile), a las policías se les enseña a interrogar desde una perspectiva agresiva y que presume la culpabilidad del sospechoso, pero que no necesariamente alcanza alguna de las hipótesis más extremas que recién mencionamos. Esta forma de interrogar, conocida como la Reid Technique, en términos sencillos consiste en aislar al sospechoso y doblegarlo, haciéndole sentir sin esperanza, convenciéndole que será condenado. Dentro de las diversas técnicas policiales que propone esta técnica, una muy relevante consiste en decirle al imputado que existe una enorme cantidad de evidencia que lo incrimina sea esto verdad o mentira. La técnica de Reid propone, además, una estrategia que es diseñada para minimizar el sentido de culpabilidad por el delito, y que la confesión es una buena manera para reducir la pena. ${ }^{39}$ En fin, son técnicas que van desde mentir y engañar al imputado, empatizar o restarle gravedad a las razones morales que tuvo para cometer el delito, ofrecerle excusas legales por las que pudo cometerlo, o interrogarlo agresivamente para generar una percepción de dominación. ${ }^{40}$

Estas técnicas han demostrado ser un factor esencial en la generación de falsas confesiones, en particular cuando se trata de sujetos vulnerables. Por ello es necesario reconocerlas, controlarlas e impugnarlas para evitar que puedan servir para condenar a un imputado "f inocente". Se podría decir, con algo de ingenuidad, que este problema estaría superado normativamente en Chile, porque el artículo 195 del CPP regula expresamente los métodos prohibidos de interrogatorio de un imputado, prohibiendo todo método de investigación o de interrogación que menoscabe o coarte la libertad del imputado para declarar, en particular todo método que afecte la memoria o la capacidad de comprensión y de dirección de los actos del imputado, en especial cualquier forma de maltrato, amenaza, violencia corporal o psíquica, tortura, engaño. ${ }^{41}$

\footnotetext{
${ }^{39}$ Véase el libro, que expone detalladamente la técnica Reid, de INBAU, Fred; REID, John, et. al, Criminal Interrogation And Confessions, Burlington: Jones \& Bartlett Learning, $5^{\circ}$ Ed., 2011. Un análisis crítico de estas técnicas, en especial a partir de la incapacidad de las "advertencias de Miranda" de transformarse en un adecuado remedio profiláctico que impida las confesiones falsas, en WHITE, "False Confessions and the Constitution", cit. nota ${ }^{\circ} 38$, pp. 118 y ss.

${ }^{40}$ Estas técnicas son aplicadas desde hace tiempo en el modelo norteamericano, al punto que fueron identificadas, en gran parte, en el famoso fallo Miranda v. Arizona, 384 U.S. 436 (1966).

${ }^{41}$ Artículo 195.- Métodos prohibidos. Queda absolutamente prohibido todo método de investigación o de interrogación que menoscabe o coarte la libertad del imputado para declarar. En consecuencia, no podrá ser sometido a ninguna clase de coacción, amenaza o promesa. Sólo se admitirá la promesa de una ventaja que estuviere expresamente prevista en la ley penal o procesal penal.

Se prohíbe, en consecuencia, todo método que afecte la memoria o la capacidad de comprensión y de dirección de los actos del imputado, en especial cualquier forma de maltrato, amenaza, violencia corporal o psíquica, tortura, engaño, o la administración de psicofármacos y la hipnosis.

Las prohibiciones previstas en este artículo rigen aun para el evento de que el imputado consintiere en la utilización de alguno de los métodos vedados.
} 
Y la respuesta es ingenua porque precisamente estos métodos de interrogatorio lo que buscan es someter al imputado, aislarlo del mundo, evitar que entre en contacto con el defensor; por lo mismo, las posibilidades de impugnar posteriormente la confesión alegando que la policía recurrió a un método no permitido -como engañar diciendo que existía mayor prueba incriminatoria que la real, cuestión que, seguramente, no va quedar registrado sino en la memoria del imputado-, va a limitarse a una confrontación de opiniones entre el policía (o el fiscal) y el imputado.

Por otra parte, si bien en la experiencia comparada el impacto de las confesiones falsas en las investigaciones sobre condenas a sujetos "f inocentes" no ha sido tan significativo como los reconocimientos erróneos, igual representan un porcentaje importante de casos de imputados injustamente condenados. ${ }^{42}$ Sin perjuicio de ello, lo relevante en el caso concreto es el impacto que las confesiones falsas tienen en la determinación de la culpabilidad por el tribunal, pues siguen siendo la reina de las pruebas porque, como lo dice Brooks, representan un fuerte antecedente de reconocimiento interno. ${ }^{43}$

Por ende, como lo sugieren Leo et al., uno de los problemas principales de las falsas confesiones es su impacto en los actores del sistema, quienes a menudo son reacios a aceptar el hecho que una persona pueda confesar un crimen que no cometió. ${ }^{44}$ Por eso, una vez que el imputado confiesa la policía suele considerar el caso cerrado y restringe las investigaciones futuras; algo similar sucede con los fiscales, quienes rápidamente toman la decisión de formalizar o acusar; y los defensores, por su parte, suelen empezar a pensar en cómo negociar una determinada pena o terminar el caso de una $u$ otra forma. Y ello porque los propios jueces son proclives - una vez superado los aspectos formales como la lectura de derechos- a considerar la confesión del imputado como una prueba bastante conclusiva y, por lo mismo, son escépticos a las alegaciones posteriores de que la confesión fue falsa u obtenida mediante un método coercitivo. ${ }^{45}$

Por todo lo anterior, y dado que las confesiones voluntarias son una realidad que no se puede -y quizás no sería siquiera deseable- suprimir, pues epistémicamente entregan información trascendental para que el adjudicador se acerque a la verdad, entonces hay dos cuestiones centrales que se deben discutir con seriedad. La primera se relaciona con la efectiva renuncia al derecho a guardar silencio y, por lo mismo, la expresa aceptación

\footnotetext{
${ }^{42}$ En el caso Regina v. Oickle, 2 S.C.R. 3, 190 D.L.R. (4th) 257, la Corte Suprema de Canada reconoció el riesgo de las confesiones falsas para las condenas erróneas, y sugirió que son tan peligrosas como los reconocimientos. En este caso la Corte revocó la decisión de suprimir la confesión, pero el análisis que hace de esta evidencia es suficientemente interesante para que su lectura sea sugerida.

${ }^{43}$ Véase, BROOKS, Peter, Troubling Confessions: Speaking Guilt in Law and Literature, Chicago: University of Chicago Press, 2000, p 4.

${ }^{44}$ Véase, LEO, Richard, "Inside the Interrogation Room", Journal of Criminal Law and Criminology Vol. $\mathrm{N}^{\circ} 86$ (1996), pp. 266-303, pp. 295 y ss.; ID., "Police Interrogation and Social Control", Social and Legal Studies Vol. $\mathrm{N}^{\circ} 3$ (1994), pp. 93-120, pp. 98 y ss. (descargable en http://papers.ssrn.com/sol3/papers.cfm?abstract_id=1141372); WHITE, "False Confessions and the Constitution", cit. nota ${ }^{\circ} 38$, pp. 125 y ss.

${ }^{45}$ Véase, LEO, Richard et al., "Bringing Reliability Back In: False Confessions and Legal Safeguards in the Twenty-First Century", Wisconsin Law Review Vol. N²006, pp. 479-539, en especial p. 485. En el mismo sentido véase LEO, Richard; KASSIN, Saul, et al., "Police-Induced Confessions: Risk Factors and Recommendations", Law and Human Behavior Vol. N 34 (2010), pp. 3-38 [texto descargable en http://papers.ssrn.com/sol3/papers.cfm?abstract id=1483878].
} 
CASTILLO, Ignacio. "Enjuiciando al proceso penal chileno desde el inocentrismo (algunos apuntes sobre la necesidad de tomarse en serio a los inocentes)."

del imputado a prestar una declaración. La segunda, relativa a los medios para registrarla y permitir su adecuada reproducción en el juicio. Salvo algunas excepciones, la mayoría de los autores que han discutido sobre el inocentrismo reconocen que ambas exigencias deben ser copulativas y son esenciales para que las confesiones puedan ser consideras con un alto valor inferencial por el adjudicador.

Respecto del consentimiento, lo que debe exigirse es un consentimiento previo y absolutamente explícito del imputado en que expresamente renuncie al derecho a guardar silencio y que, positivamente consienta en declarar sin la presencia de un abogado defensor. ${ }^{46}$ El consentimiento ficticio o incompleto (aquel que se da con posterioridad a la confesión o sin conocer en detalle el contenido material del derecho a guardar silencio) debe anular el poder legitimante del consentimiento. No basta la sola renuncia al derecho a guardar silencio, sino que el imputado debe expresamente consentir en declarar, aceptando hacerlo renunciando informadamente a su derecho a contar con un abogado defensor, o a esperar la primera audiencia judicial. ${ }^{47}$

De hecho, en la literatura comparada no son pocos los estudios que, desde las ciencias sociales, han manifestado reticencias y críticas a la capacidad de las advertencias de Miranda para proteger a ciertos imputados que se encuentran en una situación de estrés frente a la persecución policial, cuando ellas únicamente implican un acto formal de

\footnotetext{
${ }^{46}$ Indudablemente el mejor mecanismo para confirmar la voluntariedad en la declaración del imputado sería que se exigiese la concurrencia de su abogado defensor, de manera que sin su presencia no sea posible considerar una declaración como válida. Lamentablemente desde el inicio del nuevo proceso penal chileno, reafirmado hoy con la Ley 20.592, publicada el 2 de junio de 2012, se ha legitimado la declaración de imputado sin abogado defensor, bastando solamente que aquel firme un formulario general y estándar en que aparece renunciando a sus derechos, entre ellos el derecho a guardar silencio.

${ }^{47}$ La Ley 20.592, como ya se advirtió, modificó el CPP en relación al derecho a guardar silencio y a la necesidad de asegurar al imputado la presencia de un abogado defensor, previo a ser sometido a un interrogatorio. Su regulación difícilmente pudo ser peor. En lo que aquí importa, la opción legislativa se equivocó al mantener la posición -sin que existieran críticas a la misma- que basta la sola lectura formal de los derechos (entre ellos el derecho a guardar silencio) como garantía suficiente para legitimar la renuncia al derecho a no autoincriminarse. El legislador debió haber exigido, explícitamente, que los policías no solo dieran a conocer los derechos al imputado, sino que existiera una renuncia explícita -más allá de la firma de un formulario- del derecho a guardar silencio, consintiendo el imputado en declarar conociendo previamente el alcance completo de sus derechos. Segundo, el legislador perdió una oportunidad única (que lamentablemente, al menos según la historia de la ley, ni siquiera se discutió) de exigir a las policías y a los fiscales el registro en formato audiovisual de los interrogatorios. Pero, y quizás lo más grave, el legislador incluyó una frase en el nuevo artículo 93 que -influenciada por la imagen, incluso cinéfila, de la cultura norteamericana- prescribe que todo lo que el imputado diga, si renuncia a su derecho a guardar silencio, podrá ser usado en su contra. Ello, como cualquier observador podrá intuir, escapa de lo solamente simbólico (como suele verse en las películas y series policiales norteamericanas), y que seguramente tendrá más de alguna repercusión en nuestra propia jurisprudencia. Alguien podría sostener, con bastante razón, que esa norma viene a eliminar la discusión respecto de si los policías que escuchan un interrogatorio pueden concurrir al juicio a prestar declaración de lo que escucharon, o incluso más, se podría justificar (en una interpretación extensiva, pero no del todo irreal) que esa modificación normativa -en razón de su posterioridad- modifica el artículo 331 y 334, y la declaración incriminatoria del imputado (una vez considerada por el juez como obtenida observando los derechos fundamentales) podría perfectamente ser leída en el juicio oral como documento. En fin, salvo por el hecho que la nueva normativa prescribe explícitamente que no se pueden inferir consecuencias negativas del silencio, el resto son todas malas noticias.
} 
lectura de derechos. ${ }^{48}$ Si los imputados, en particular aquellos más vulnerables (jóvenes mayores de edad, abusadores de sustancias sicotrópicas, sujetos con menores capacidades cognitivas o un verdadero inocente) se encuentran sometidos al nivel de estrés que supone un interrogatorio policial, es probable que los mecanismos profilácticos de las advertencias no sean capaces de proteger al imputado en la medida que se pensó originalmente que lo harían. ${ }^{49}$

Por lo mismo, hay que alejarse de aproximaciones formalistas que simplemente se preocupan de que previo al interrogatorio exista una lectura formal de derechos a partir de la cual se crea que el imputado, como agente autónomo racional de quien se espera que conozca sus derechos y los proteja, está en condiciones de tomar la mejor decisión. ${ }^{50}$

Así, la lectura de derechos que hoy se practica no debería tener una gran relevancia para sugerir que el imputado efectivamente entendió sus derechos, los evaluó razonablemente y que luego pudo tomar la decisión que autónomamente más apreciaba como conveniente. Por el contrario, las circunstancias que rodean a los interrogatorios lejos de aportar a ello lo cubren con un manto de dudas. En efecto, y como ya se señaló, no debe olvidarse que los interrogatorios normalmente implican aislar al imputado de terceros imparciales que puedan protegerlo de coacciones o de engaños. Pero además, las actuales tácticas de interrogatorio que se usan en el mundo -y que quizás las policías chilenas conocen- han sido especialmente concebidas para subyugar al imputado a la voluntad del interrogador. En este contexto, la sola lectura de un formulario de derechos -dentro de los cuales se explicita el derecho a guardar silencio- parece ser insuficiente para alcanzar el estándar de legitimación necesario que el Estado debe mostrar para validar esta diligencia.

Por lo mismo los jueces, sea de garantía como también de juicio oral, deberían ser extremadamente estrictos para dar por acreditada y valorar una confesión prestada sin presencia del abogado defensor, sea esta policial o ante el fiscal, requiriendo siempre toda la información de la diligencia, la que debería abarcar aspectos tales como: $a$ ) quién tomó la confesión, $b$ ) cuántos policías participaron en la diligencia, $c$ ) estaban o

\footnotetext{
${ }^{48}$ En este sentido puede observarse el estudio de SCHERR, Kyle; MADON, Stephanie, "You Have the Right to Understand: The Deleterious Effect of Stress on Suspects' Ability to Comprehend Miranda", Law and Human Behavior, Vol. N 36 (Aug. 2012), pp. 275- 282.

49 Como lo explica White, las "técnicas actuales de interrogación, aplicadas a un sospechoso particularmente vulnerable a esas presiones, pueden producir dos tipos de falsas confesiones: la de quien sabe que está dando una falsa confesión pero lo hace para obtener algún fin o para "escapar de una situación estresante o intolerable"; o de quien internaliza la coerción a tal punto que comienza a creer que es verdaderamente el culpable". Véase, WHITE, "False Confessions and the Constitution", cit. nota $n^{\circ}$ 38, p. 109.

${ }^{50}$ Esta ha sido una de las principales críticas a la jurisprudencia norteamericana que ha sucedido a Miranda, en cuanto la Corte Suprema pareciera alejarse de la aproximación que buscaba proteger y prevenir abusos sobre sujetos vulnerables (Miranda) hacia una donde lo relevante es el "juego justo" en el sentido en que el imputado sea simplemente informado de sus derechos, dando paso a lo que se ha denominado la "muerte" de Miranda y el renacimiento de un "nuevo" Miranda -mucho menos garantista. Para una amplia revisión de la jurisprudencia referente a las confesiones en el sistema estadounidense, después de Miranda, véase, WITMER-RICH, Jonathan, "Interrogation and the Roberts Court", Florida Law Review Vol. N 63 (2011), pp. 1189-1243. En el artículo el autor reivindica la necesidad de que el imputado "explícitamente y de manera voluntaria" consienta en declarar y renuncie a su derecho a guardar silencio, a contar con un abogado defensor, etc.
} 
CASTILLO, Ignacio. "Enjuiciando al proceso penal chileno desde el inocentrismo (algunos apuntes sobre la necesidad de tomarse en serio a los inocentes)."

no armados, $c$ ) el imputado estaba o no esposado, $d$ ) estaba o no presente un fiscal, $e$ ) cómo era exactamente la dependencia física en que se realizó la diligencia (ventanas, puertas, mesas, etc.), $f$ ) cuándo y cómo se le leyeron los derechos al imputado, $g$ ) cuántas veces se le leyeron, $g$ ) la hora precisa en que comenzó la diligencia y cuánto tiempo demoró hasta que el imputado comenzara a confesar, $h$ ) cuando terminó la diligencia, y si hubo pausas intermedias (y si en cada reinicio se le volvieron a leer los derechos), $i$ ) qué tipo de promesas se le hicieron al imputado, $j$ ) y si el imputado realizó o no alguna solicitud durante el interrogatorio, etc.

Sólo a partir de estos antecedentes, como mínimo, los jueces podrían contar con la información necesaria para, primero, efectivamente hacer un control cautelar de la diligencia que les permita ponderar si la lectura de derechos fue lo suficientemente seria, idónea y completa para considerar legítima la renuncia del imputado al derecho a guardar silencio y, segundo, para asignarle a esa evidencia un alto valor en la adjudicación, al menos lo suficiente para no ser cuestionada bajo el baremo de la duda razonable.

Como segunda cuestión, ya más centrada sobre el mérito cognoscitivo de la prueba, es trascendental reiterar la necesidad de mejorar -tanto respecto de los interrogatorios en las policías como en el Ministerio Público- el registro de las confesiones. En Chile, cabe recordar, al día de hoy las confesiones quedan registradas en un documento redactado por el policía o el fiscal (o su asistente) y si bien es firmada por el imputado y su defensor, si está-, no escapa a la capacidad de edición de quien hace la transcripción. Sumado a ello, para el caso que el imputado confiese en la etapa de investigación y luego decida no declarar en el juicio, parte importante de la jurisprudencia ha autorizado que sean los propios funcionarios policiales, como testigos de oídas, los que luego en el juicio relaten el contenido de esa declaración, con todo lo sugestivo y arbitrario que ese proceso pueda resultar. Este es, claramente, un sistema que no tiene en cuenta bajo ningún punto de vista la protección de los imputados inocentes.

Para superar esto, se debería avanzar hacia un sistema de grabación audiovisual auditado externamente. Esto ha sido más pacífico, incluso en nuestra doctrina, ${ }^{51}$ aunque no ha tenido eco en las autoridades policiales ni el Ministerio Público. La grabación de los interrogatorios es la más extendida medida que se ha propuesto para evitar las falsas confesiones. Las grabaciones electrónicas protegen al inocente al desincentivar excesivas e ilegales coacciones, además de permitirle al juez conocer exactamente cuál fue el "proceso" de convencimiento utilizado para que el sujeto declarara, apreciar el nivel de conocimiento de sus derechos y tener una versión completa -y no "mejorada"de la confesión. Por último, ayuda a tener información de mejor calidad para dilucidar cuestiones de pertinencia y admisibilidad de la confesión.

\footnotetext{
51 Así, por ejemplo, DUCE, Mauricio; RIEGO, Cristian, Proceso Penal, Santiago: Editorial Jurídica de Chile, 2007, p. 475. En el sistema norteamericano la cuestión ha sido apoyada por una amplia literatura, a modo de referencia véase, JOHNSON, Gail, "False Confessions and Fundamental Fairness: The Need for Electronic Recording of Custodial Interrogations", Public Interest Law Journal Vol. 6 (1997), pp. 719751, en especial pp. 746-751; KAMISAR, Yale, "On the "Fruits" of Miranda Violations, Coerced Confessions and Compelled Testimony", Michigan Law Review Vol. ㅇ 93 (1995), pp. 929-1010, p. 934 en especial la cita 19; WHITE, "False Confessions and the Constitution", cit. nota n 38, pp. 152 y ss.
} 
Sin embargo, la experiencia comparada demuestra que las policías y los fiscales suelen ser reacios a aceptar las grabaciones, y su primera justificación es que ello genera un costo y requiere de una logística difícil de alcanzar. Pero, en realidad, lo que está detrás de esas razones es el temor a que los imputados no quieran confesar si saben que son grabados. ${ }^{52}$ En todo caso, en los países -o en algunos estados de Estados Unidos- en que se han exigido las grabaciones, las policías y las fiscalías finalmente lo han percibido como una gran ayuda, porque permite concentrarse en el interrogatorio y no en el registro, porque además después les sirve para ir detectando inconsistencias u otra información que en su momento pudo no ser considerada relevante $\mathrm{y}$, por último, para evitar los cuestionamientos e impugnaciones por las infracciones a los derechos fundamentales. También los otros intervinientes la han considerado una gran medida porque permite mejorar la calidad de la prueba y, por lo mismo, la confianza en que se puede adjudicar con mejor evidencia. ${ }^{53}$

Por último, a diferencia de lo que se ha sostenido por ciertos autores norteamericanos, creo que el registro audiovisual completo de las confesiones no debería ser adoptado a cambio de las advertencias de Miranda, porque ambas medidas -aunque con finalidades diversas- tienen externalidades que igualmente se complementan. ${ }^{54} \mathrm{Si}$ bien las advertencias sobre el derecho a guardar silencio, a contar con un abogado defensor durante el interrogatorio y a terminar la declaración cuando se quiera, apuntan a asegurar el debido proceso (procedural justice), a reforzar la autonomía del individuo y a desincentivar que la persecución tome ventaja a costa del imputado, ellas también se relacionan con un mejor acercamiento a la verdad. Y, por otro lado, si bien las grabaciones buscan asegurar una mayor integridad de la información, a fin de que el adjudicador pueda adoptar - con mayor seguridad- una decisión que corresponda mejor con la realidad, en menor parte también tienen una función profiláctica de protección del debido proceso, porque incentivan el mayor respeto a los derechos fundamentales. En definitiva, en vez de optar por una u otra, deberían incentivarse ambas.

De hecho, la Comisión de la NYSBA recomendó tres cosas respectos de las falsas confesiones:

1. Que todos los interrogatorios en custodia, de imputados investigados por cierta categoría de delitos (felony), deberían ser electrónicamente grabadas en su integridad.

\footnotetext{
${ }^{52}$ Véase, SULLIVAN, Thomas, "Electronic Recording of Custodial Interrogations: everybody wins", The Journal of Criminal Law and Criminology Vol. No 95 (2005), pp. 1127-1144, p. 1129; ID., "Police experiences with recording custodial interrogations”, Judicature Vol. N 88 (2004), pp. 132-136.

53 En todo caso, debe destacarse una cierta dicotomía entre las protecciones profilácticas para evitar vulneraciones a derechos fundamentales (v.gr. como el derecho a guardar silencio) y las razones epistémicas para mejorar la calidad en la información que tiene el adjudicador. Porque si el sistema está dispuesto a registrar las confesiones de los imputados (mejorando con ello también la prueba sobre su voluntariedad) una vez pasado el cedazo de la pertinencia y la no exclusión de la prueba por ilicitud de su obtención, no habría ninguna razón lógica para evitar que la misma sea reproducida en el juicio, incluso si el imputado decide no declarar. Esto es obvio, al menos que alguien quiera sostener que el derecho a guardar silencio es una garantía del juicio oral, y que por lo mismo es ahí donde el imputado tiene o no el derecho de declarar. Esa posición no tiene sustento normativo ni sistémico. De hecho hoy, con la modificación de la ley $\mathrm{N}^{\circ} 20.592$, parece una cuestión zanjada.

${ }^{54}$ Así lo han sostenido, de manera sutil, ALLEN, Ronald; LAUDAN, Larry, "Deadly Dilemmas", Texas Tech Law Review Vol. № 41 (2008-2009), pp. 65-92, p. 89. Y de manera más directa CASSELL, Paul, "Miranda's Social Costs: An Empirical Reassessment", Northwestern University Law Review Vol. № 90 (1996), pp. 387-498.
} 
CASTILLO, Ignacio. "Enjuiciando al proceso penal chileno desde el inocentrismo (algunos apuntes sobre la necesidad de tomarse en serio a los inocentes)."

2. Que a las policías, defensores, fiscales y jueces se les debería dar entrenamiento específico sobre las falsas confesiones, sus causas, mecanismos de prevención, detección y formas de corrección.

3. Que se deberían realizar más estudios empíricos en el impacto del fenómeno de las falsas confesiones (o simplemente de aceptación) en la voluntad del imputado de someterse a un procedimiento autoincriminatorio. ${ }^{55}$

En conclusión, de la experiencia comparada del inocentrismo y del estado actual de las confesiones en Chile, se deberían considerar urgentemente tres mejoras centrales si queremos prevenir la condena de imputados inocentes, a saber: exigir transparencia en las autoridades policiales para que expliciten el método de interrogación que las policías utilizan con los imputados; segundo, exigir que la renuncia del derecho a guardar silencio y a no autoincriminarse del imputado sea mediante una manifestación expresa que incluya el conocimiento completo del alcance del derecho, por ejemplo, de poder contar con un abogado defensor (el imputado debería manifestar algo como "estoy dispuesto a declarar sabiendo que puedo no hacerlo e, incluso, a declarar sin contar con un abogado defensor, como sería mi derecho"); tercero, la necesidad de que las confesiones sean completa y totalmente grabadas, para que el juez (cautelar y adjudicador) tenga la versión íntegra de dicha prueba, sin ningún tipo de adorno o modificación.

\section{Los reconocimientos de imputados. ${ }^{56}$}

\footnotetext{
${ }^{55}$ Reporte de la Comisión de la NYSBA, cit. nota $n^{\circ} 36$, p. 104-113.

${ }^{56}$ Quiero utilizar dos casos del sistema norteamericano para que el lector pueda apreciar la gravedad del asunto que se va tratar. John Jerome White fue arrestado en 1979 por un robo con violación que había ocurrido seis semanas atrás. Fue condenado en 1980 por ese crimen y luego fue liberado en el 2007 dado que una prueba de $\mathrm{ADN}$ demostró su inocencia. En su proceso, la víctima lo identificó primero en un reconocimiento fotográfico, declarando que estaba casi segura que White era su agresor. Una semana después White fue puesto en un reconocimiento en rueda de imputados de cinco sujetos. En ese momento, la víctima aseguró que él había sido el autor de los delitos. Lo relevante del caso, que tiene algo de fatalidad e ironía, es que el verdadero responsable del delito estaba en la misma rueda de reconocimiento junto a White y, así y todo, la víctima no lo reconoció. Aunque parezca la más cruel de las ironías en el momento del reconocimiento en rueda de imputados el verdadero violador había sido detenido por otro delito y fue reclutado para el reconocimiento. Pero como la víctima ya había identificado a White en el primer reconocimiento fotográfico, el destino de White estaba en buena parte jugado. El otro caso es el de Ronald Cotton que estuvo más de una década preso por una violación que no cometió hasta que una prueba de ADN demostró su inocencia y fue liberado en 1995. La víctima de la violación reconoció primero a Cotton en un reconocimiento fotográfico y después ratificó su reconocimiento en una rueda de imputados. La prueba de ADN no sólo permitió demostrar que Cotton era inocente, sino que permitió identificar al verdadero autor. Sin embargo, cuando la víctima fue enfrentada al verdadero violador, continuó negando que fuera su agresor y persistió en su convicción de que Cotton era el culpable. Después, en todo caso, se convenció de su propio error. Ambos casos fueron detenidamente seleccionados, la prueba de ADN conservada había sido obtenida del líquido vaginal de la víctima, se trataba de agresiones donde la víctima había dicho desde el inicio que sólo había participado un agresor, y donde el verdadero agresor fue identificado porque su ADN era efectivamente compatible con el del líquido vaginal. Para revisar los casos véase, STEBLAY, Nancy, "Maintaining the Reliability of Eyewitness Evidence: After the Lineup", Creighton Law Review Vol. N 42 (2009), pp. 643-654, en especial p. 648. Una revisión completa del caso Cotton, además de un excelente análisis sobre los problemas epistémicos de los testigos oculares, y en especial por sus reconocimientos, véase, WISE, Richard; FISHMAN, Clifford; SAFER, Martin, "How to Analyze the Accuracy of Eyewitness Testimony in a Criminal Case", Connecticut Law Review Vol. N 42, n 3 (2010), pp. 435-513, en especial pp. 435 y ss.
} 
Como dicen Morales y Welsch el reconocimiento de imputados es una diligencia trascendente en la etapa investigativa del proceso penal, toda vez que otorga elementos para el desarrollo de una línea de indagación determinada, en relación a la participación de determinados imputados en el hecho delictivo. ${ }^{57}$ Esta definición, aunque acertada, es sólo parcialmente completa, porque no cabe duda que la diligencia de reconocimiento de imputados es fundamental para la etapa de investigación, pero omite un aspecto relevante, que ella es también vital en la etapa de adjudicación. Es ahí donde se debe finalmente medir su validez y valor probatorio, y es ahí donde deben existir los últimos mecanismos de salvaguarda para evitar darle mayor peso inferecial que el que debe tener. En otras palabras, es claro que los reconocimientos son una diligencia fundamental para que las policías y los fiscales puedan ir avanzando en la identificación de un posible sospechoso, pero también es necesario reconocer que ella debe ser estrictamente analizada y valorada en sede de adjudicación, pues su deficiente ejecución inicial, además de generar una investigación sesgada, puede terminar -como de hecho ocurre en muchos casos- con la condena de un imputado " $f$ inocente". 58

A pesar de su utilidad, los reconocimientos de imputados hace tiempo se identificaron como particularmente poco fiables -especialmente cuando se trata de reconocimiento entre extraños- y, por lo mismo, son una herramienta problemática en la búsqueda de la verdad, pues dificultan la condena del culpable y son una fuente de error inagotable en la condena de imputados " $f$ inocentes". ${ }^{59}$ De hecho, la literatura comparada sostiene que los reconocimientos imprecisos son, a menudo, causados por la manera imperfecta en que los seres humanos procesan la información visual, sumado a un diseño en los procedimientos policiales que, lejos de controlar esas imperfecciones, las refuerzan o exacerban, sumado a un sistema judicial, tanto en sede de garantía como adjudicativo, ineficiente para limitar y controlar sus efectos perniciosos. ${ }^{60}$ Por otra parte, la razón por

\footnotetext{
57 Véase, MORALES, Ana Maria; WELSCH, Gherman, El reconocimiento de imputados en Chile y a nivel comparado, Santiago: Fundación Paz Ciudadana, julio 2011, p. 5. En este importante texto los autores explican los problemas asociados a los reconocimientos, la (nula) regulación normativa que tienen estos procedimientos en Chile; dan cuenta -resumidamente- de la actualidad de la discusión en España, Inglaterra y Estados Unidos, y terminan dando algunas recomendaciones para mejorar los reconocimientos en Chile. Sin perjuicio del mérito del texto, no puede obviarse la enorme perplejidad que produce observar que respecto de la normativa interna de las policías y las fiscalías, el texto decidió eliminarlas por el carácter reservado de la información. Ello, seguramente solicitado por ambas instituciones, además de ser una pésima señal de transparencia, se contrapone a las mejores prácticas de otros países, donde precisamente por el alto riesgo de producir condenas erróneas que tienen los mecanismos de identificación, sus procedimientos son altamente sensibilizados con los otros actores y la comunidad académica. Sin duda esta es una inquietante señal del Ministerio Público y de las policías.

${ }^{58}$ En este punto vuelvo a invitar al lector a revisar la sentencia RIT 100-2007 del 5to Tribunal Oral en lo Penal de Santiago y el Recurso de Revisión 12.018-2011 de la Corte Suprema, que se pronunció sobre la misma. En ambas resoluciones se puede apreciar el efecto devastador sobre la libertad de una persona cuando un proceso penal se desarrolla con una evidente visión de túnel, surgida de un pésimo proceso de reconocimiento del imputado.

${ }^{59}$ Véase, RISINGER/RISINGER, "Inocence is Different", cit. nota 31, p. 24. Como dice Guerra, los "reconocimientos erróneos de testigos oculares siguen aportando [cada día] nuevos casos de condenas erróneas". GUERRA, Sandra, "Eyewitness Identifications and State Courts as Guardians Against Wrongful Conviction”, Ohio State Journal Of Criminal Law Vol. N 7 (2010), pp. 603-635.

${ }^{60}$ En razón de esto, el año 1999, el Department of Justice de Estados Unidos publicó un Research Report denominado Eyewitness Evidence, A Guide for Law Enforcement, que buscaba precisamente dar los primeros lineamientos (con carácter simplemente de recomendaciones) de cómo debían realizarse los reconocimientos. Este documento, que hoy es ampliamente conocido, se encuentra actualmente bastante desactualizado.
} 
CASTILLO, Ignacio. "Enjuiciando al proceso penal chileno desde el inocentrismo (algunos apuntes sobre la necesidad de tomarse en serio a los inocentes)."

la que el reconocimiento de testigos oculares es frecuentemente motivo de condenas erróneas es porque se trata de uno de los medios probatorios más convincentes que pueden ser presentados en contra de un imputado. ${ }^{61}$

En Estados Unidos, a propósito de la investigación del inocentrismo, se ha sostenido que los reconocimientos erróneos de imputados constituyen la principal explicación de las condenas a imputados "finocente". ${ }^{62} \mathrm{Y}$, si bien el sistema norteamericano no tiene en este aspecto- lo que uno podría llamar un modelo particularmente garantista, al menos sirve como referente para ver cómo se ha ido generando la discusión en torno al fenómeno en cuestión y para comprender por qué la forma en que se ha resuelto por la jurisprudencia ha sido ineficiente para evitar la condena de imputados inocentes. ${ }^{63} \mathrm{En}$ efecto, la Corte Suprema de Estados Unidos, a partir del caso Neil v. Biggers, ${ }^{64}$ ha diseñado un doble examen respecto de la admisibilidad de las identificaciones. Ha dicho que la defensa tiene la carga de la prueba para demostrar que el procedimiento de identificación fue indebidamente sugestivo y, sólo para el evento que logre superar ese baremo $-\mathrm{O}$ sea el juez considere que efectivamente el procedimiento fue innecesariamente sugestivo-, entonces la carga de la prueba se traslada al Ministerio Público quien ahora debe probar que el procedimiento es creíble bajo el paragua de la totalidad de las circunstancias. La Corte termina diciendo, entonces, que si una vez hecho ese análisis de la totalidad de las circunstancias el reconocimiento es suficientemente creíble, entonces no hay afectación del debido proceso. ${ }^{65}$

${ }^{61}$ Véase, WISE, et al., "How to Analyze the Accuracy of Eyewitness", cit. nota ${ }^{\circ} 56$, p. 441.

62 De las primeras 250 exoneraciones por ADN, más de tres cuartas partes de ellas involucraron reconocimientos equivocados. De esos casos, más del 36\% incluyó, además, reconocimientos múltiples que, así y todo, terminaron siendo incorrectos. Y en la gran mayoría de esos casos, estos reconocimientos múltiples eran una de las evidencias más fuertes de la fiscalía. Véase, RISINGER/RISINGER, "Innocence is Different" cit. nota $\mathrm{n}^{\circ} 31$, p. 25, citando a GARRETT, Brandon, Convicting the innocent: Where Criminal Prosecutions go Wrong, Boston: Harvard. Univ. Press, 2011. En el mismo sentido, GOULD, Laurie; VON HATTEN, Brian; STICKELS John, "Reforming the use of Eyewitness Testimony”, Oklahoma City University Law Review Vol. ㅇ 35 (2010), pp. 131-146.

${ }^{63}$ A pesar de la ineficiente respuesta jurisprudencial, cabe destacar que en el sistema norteamericano, a partir de la década pasada, y en especial luego que se hicieran conocido varios casos de inocentes injustamente condenados debido a problemas en los procesos de identificación, algunos Fiscales Generales estatales empezaron a exigir a las policías que las prácticas de los reconocimientos se realizaran conforme a las mejores experiencias que se habían sugerido en diversos estudios sicológicos. Así, por ejemplo, en el 2001, John J. Farmer, el Fiscal General de New Jersey, instruyó a todos los fiscales del estado y a las distintas autoridades policiales a practicar los reconocimientos siguiendo estrictos protocolos, que habían sido ya sugeridos por el Department of Justice. Asimismo, en el 2002, el Poder Judicial de North Carolina en conjunto con el Fiscal General del estado, invitaron a distintos actores y académicos vinculados al sistema de persecución penal, incluidas las policías, a trabajar durante años en distintos aspectos para mejorar la asertividad de los procesos. A partir de ese proceso se creó la North Carolina Actual Innocence Commission que finalmente propondría un proyecto de ley específico sobre reconocimiento de testigos, que finalmente fue aprobado el 2008.

${ }^{64}$ Neil v. Biggers, 409 U.S. 188, 199 (1972).

${ }^{65}$ La otrora incipiente y garantista jurisprudencia norteamericana ha ido retrocediendo en la fijación de estándares adecuados para evitar reconocimiento erróneos, hasta arribar a un estándar derechamente desechable. En efecto, actualmente los únicos reconocimientos que tienen una protección judicial relevante son aquellos realizados con posterioridad a la formalización de los hechos. En ese momento, que la Corte ha definido como critical stage, el imputado tiene derecho a que su defensor participe del procedimiento de reconocimiento en rueda y, si se viola ese derecho, el reconocimiento no puede realizarse en el juicio - de hecho no se le puede preguntar al testigo o a la víctima en el juicio respecto del reconocimiento- salvo que el fiscal demuestre por evidencia clara y convincente (estándar inferior al de más allá de toda duda razonable) que la identificación en el juicio se basa sobre la observación del 
El problema de este razonamiento, como es fácil de percibir, es que es extremadamente subjetivo y arbitrario, además centra la discusión en preocupaciones de garantía y de respeto a los derechos fundamentales, pero no especialmente respecto de los problemas epistémico de la evidencia. Por lo mismo, desconoce los cuestionamientos sicológicos que se esconden detrás del problema de los reconocimientos, que tienen más que ver con el funcionamiento de la naturaleza humana, en general, y de la memoria, en particular. En fin, como dicen Wise et alii, olvida que toda persona codifica los hechos vividos con sus propios sesgos y, en especial, si esa codificación se refiere a hechos importantes como un delito, entonces puede suceder que en la memoria quede guardado no sólo lo que el testigo vio durante el delito, sino que también el sentido que le dio a lo que vio, y ese significado viene influenciado por sus expectativas, actitudes, creencias y conocimientos. 66

Sumado a lo anterior, la jurisprudencia norteamericana omite que existen ciertas categorías de víctimas o testigos respecto de los cuales se debería tener una especial preocupación en lo que se refiere a las identificaciones, porque tienen características específicas que en algún sentido pueden afectar su capacidad de percepción e identificación. La literatura comparada identifica en este grupo a los menores de edad, por el hecho que son más susceptibles a situaciones de sugestibilidad, influenciabilidad y presiones; ${ }^{67}$ los adultos mayores, que comparten ciertas situaciones con los menores y que, según lo demuestran estudios empíricos, suelen realizar más falsos positivos identifican cuando el culpable no compone la línea-, probablemente para no frustrar a los investigadores y no demostrar debilidades; las policías; testigos o víctimas bajo estado de ebriedad o con alguna otra circunstancia que alteren su capacidad de percepción. $^{68}$

Ahora bien, analizado el contexto general de los reconocimientos y su relación con las condenas de imputados inocentes, debemos revisar su regulación en Chile y la forma en que se realizan, para ver el nivel de vulnerabilidad del sistema respecto de la posibilidad de condenar a sujetos inocentes. En esto hay que ser claros, la situación en Chile no podría ser peor. Sumado a la inexistente regulación en el CPP respecto de la oportunidad y la forma en que se deben realizar estas diligencias, y a la débil y poco comprometida preocupación del Ministerio Público para hacerse cargo del tema (con excepción de un instructivo regional redactado al respecto, pero de limitada aplicación)

imputado en el delito y no en el reconocimiento. Los reconocimientos (exhibiciones cara a cara, fotográficos y en rueda de imputados) antes de la formalización, en general, no tienen mayor protección jurisprudencial, salvo la cláusula genérica del debido proceso que ha demostrado ser absolutamente ineficaz para evitar reconocimientos sugestivos. Sobre esto véase, WISE, et al., "How to Analyze the Accuracy of Eyewitness", cit. nota ${ }^{\circ} 56$, p. 455.

${ }^{66}$ Véase, WISE, et al., "How to Analyze the Accuracy of Eyewitness", cit. nota n 56, pp. 455 y ss.

${ }^{67}$ Particularmente escépticos con la capacidad de los menores para reconocer en rueda de imputados incluso en exhibiciones- a los autores de los delitos, y su tendencia a adivinar, en LINDSAY, R.C.; POZZULO, Joanna; GRAIG, Wendy, et al., "Simultaneous Lineups, Sequential Lineups, and Showups: Eyewitness Identification Decisions of Adults and Children", Law and Human Behavior Vol. 21 (1997), pp. 391-404, p. 392. En otro ámbito, sobre los costos que hoy está teniendo -en el sistema norteamericano- para el debido proceso, el incremento, en algunos casos excesivos, de los mecanismos de protección de los menores que alegan ser víctimas de delitos sexuales, y el evidente riesgo que ello implique más condenas de inocentes, véase, GERSHMAN, Bennett, "Child Witnesses and Procedural Fairness", American Journal of Trial Advocacy Vol. N² 24 (2001), pp. 585-608. pp. 585 y ss.

${ }^{68}$ Véase, WISE, et al., "How to Analyze the Accuracy of Eyewitness", cit. nota ${ }^{\circ} 56$, pp. 497 y ss. 
CASTILLO, Ignacio. "Enjuiciando al proceso penal chileno desde el inocentrismo (algunos apuntes sobre la necesidad de tomarse en serio a los inocentes)."

las policías realizan los reconocimientos -en cualquiera de sus formas, o sea en rueda, fotográfica y cara a cara- con absoluta arbitrariedad, siguiendo mínimos protocolos (absolutamente insuficientes para garantizar una adecuada diligencia) y sin ninguna preocupación por no afectar la calidad de la evidencia.

Por otro lado, existe una imprecisa $y$, hasta cierto punto, contradictoria jurisprudencia, que no ha sido en lo absoluto zanjada por la Corte Suprema, y que no termina por generar un control adecuado de los reconocimientos, cómo si no tuviera en consideración los riesgos que ello supone en la condena de inocentes. Lo complejo de esta situación, es que esto se ve agravado porque existe una dicotómica aproximación al problema. Mientras alguna jurisprudencia lo visualiza como un aspecto vinculado casi únicamente a las garantías, y por lo mismo trata de limitar la discusión a la admisibilidad de los reconocimientos cuando no se habrían respetado ciertos derechos fundamentales; otra, en cambio, lo ve como una cuestión que se podría llamar de discrecionalidad epistémica, a saber, asume que es el tribunal el que debe, sobre la base de la totalidad de las circunstancias (holísticamente), determinar el valor inductivo que le resulte razonable otorgar a la diligencia, para acreditar o desacreditar la proposición fáctica sobre la veracidad de la participación del imputado, ${ }^{69} \sin$ tomar en consideración con especial atención y particularidad (atomísticamente) la forma en que se hizo originalmente el reconocimiento.

Lo anterior genera una absoluta arbitrariedad, donde el control sobre esta actividad de la etapa de investigación será completamente diverso dependiendo de la judicatura que tenga competencia sobre el caso. Para algunos la infracción de garantía que supone la realización de cierto tipo de reconocimiento (o la forma en que se practicó) será suficiente para impedir que el mismo pueda ser conocido por el adjudicador o, en el caso que no sea excluida, éste último le restará valor por considerar que se vulneraron las garantías. Para otros, en cambio, el reconocimiento será apreciado en el conjunto de la prueba y, en ciertos casos, se terminará por subvalorar los problemas de la realización de la diligencia para, en conjunto con toda la evidencia, darle un alto valor inferencial. Me parece que ambas aproximaciones merecen ser matizadas.

Es evidente que ciertos casos -particularmente aquellos que impliquen un procedimiento ostensiblemente sugestivo o bien coercitivo- podrán resolverse desde la protección del debido proceso y el derecho a defensa, eventualmente impidiendo que esa diligencia entre al juicio y sea siquiera conocida por el adjudicador. Pero en la gran mayoría de los casos el incumplimiento de un protocolo riguroso sobre la realización de

\footnotetext{
${ }^{69}$ A modo simplemente de ilustración, respecto de la dificultad en el tratamiento de los reconocimientos en nuestro país, la falta de regulación normativa y de una adecuada jurisprudencia respecto del mismo, que finalmente deja entregado el mismo a un análisis holístico de toda la prueba en el juicio que permitiría justificar, en vía de inferencia, la participación de los imputados en el delito, sin fijar criterios claros de cómo debe realizarse este procedimiento, véase la resolución $\mathrm{N}^{\circ}$ 23-2008 de la Corte de Apelaciones de San Miguel. En ella, en los considerandos 6 to y $7 \mathrm{mo}$ la Corte acoge el recurso de nulidad argumentando que los jueces no justificaron suficientemente el por qué le restaron valor al reconocimiento hecho por la víctima tanto en el lugar (realizado auto a auto, en movimiento), cómo después en el propio juicio oral. En efecto los jueces lo habían hecho, sobre la base de establecer cuestionamientos a la forma en que se realizó el procedimiento. En esa sentencia se aprecia como la Corte, lejos de establecer baremos sobre los cuales es posible considerar adecuadamente realizado el procedimiento de identificación, prefirió en cambio desacreditar el razonamiento utilizado por los jueces para restarle valor epistémico.
} 
la diligencia, más que importar problemas de garantías, debería determinar en el adjudicador un descrédito del mérito probatorio de la misma, principalmente porque ello ha sido advertido por el conocimiento científico.

Por ello, es imprescindible que el juez, cautelar y adjudicador, sume a los criterios usualmente utilizados de certeza, visión y atención en el reconocimiento (que, como lo demuestra la investigación específica sobre el punto, en general son autoafirmados por los testigos), un enfoque determinado hacia los criterios y procedimientos a partir de los cuales se desarrolló la diligencia, para acrecentar o disminuir su valoración. En definitiva, controlar si se cumplieron escrupulosamente los estándares y protocolos que la comunidad científica ha sugerido para que un determinado reconocimiento sea confiable. Así, por ejemplo, el estándar de convicción del juicio oral, que permite condenar cuando el tribunal adquirió, más allá de toda duda razonable, la convicción de la participación del imputado podría servir, precisamente, para este punto, porque cumple una función que excede el carácter cognoscitivo del juicio, exigiendo la distribución de los riesgos de una decisión errada siempre en una perspectiva muy favorable al imputado. En definitiva, si compartimos la tesis según la cual la duda razonable no tiene necesariamente una razón epistémica, sino que básicamente un reforzamiento político criminal de esa función cognoscitiva, en términos tales de distribuir los riesgos sistemáticamente a modo de favorecer a los acusados (para preferir la libertad), entonces la forma de darle contenido a ese estándar -y sacarlo de la arbitrariedad del íntimo convencimiento- sería exigir procedimientos de identificación que, conforme la lógica y los estudios científicos, demuestren también reducir el riesgo de la condena de un imputado "finocente".

La primera de estas exigencias, por lo demás bastante obvia, debería ser que previo a cualquier tipo de reconocimiento la víctima o el testigo den una descripción lo más acabada del sospechoso, y para ello el funcionario a cargo de la investigación debería consultarle la mayor cantidad de detalles que recuerde, pues ello luego será útil para determinar, primero, el grado de precisión en los detalles que la víctima o el testigo recordaban previo a la diligencia (control ex ante) pero, también, para valorar con posterioridad al reconocimiento el nivel de concordancia entre esa descripción inicial y el sujeto identificado en la diligencia (control ex post). Otra exigencia, que debería ser adoptada a la brevedad, es la del administrador ciego - o del doble ciego-, a saber, un proceso de reconocimiento en el cual el funcionario a cargo de la diligencia desconozca a los testigos que participan del reconocimiento, pero principalmente ignore cuál de los sujetos en la rueda de imputados o en el kardex fotográfico es el sospechoso del delito. Además, los testigos y las víctimas que participen del reconocimiento deberían ser expresamente informados que el sospechoso puede o no estar ubicado dentro de la rueda, y que el administrador de la diligencia desconoce la identidad (y por cierto la apariencia) de la persona sospechosa. ${ }^{70}$ La relevancia del administrador ciego no sólo sirve para evitar la contaminación o para prevenir que el responsable de la diligencia entregue información inadecuada ex ante a la víctima o a los testigos, sino también para evitar que el encargado -o cualquier otra persona- pueda confirmar ex post, a quienes participaron del reconocimiento, acerca del resultado de su identificación. Lo anterior -

\footnotetext{
${ }^{70}$ Queda fuera de discusión que uno de los requisitos pilares de la rectitud de la diligencia es reforzar la voluntariedad con que el testigo (o la víctima) participa del reconocimiento. El testigo no se puede sentir compelido a participar de la diligencia.
} 
CASTILLO, Ignacio. "Enjuiciando al proceso penal chileno desde el inocentrismo (algunos apuntes sobre la necesidad de tomarse en serio a los inocentes)."

como lo ha destacado la doctrina comparada- genera un efecto de acrecentar la certeza en los testigos respecto de sus identificaciones y, lo que es más problemático, respecto de la propia certeza al momento exacto de la primera identificación -la del delito. ${ }^{71} \mathrm{De}$ hecho, esa confirmación suele acrecentar la percepción del testigo respecto de su propia evaluación acerca de la memorización de la experiencia vivida al momento de presenciar $-\mathrm{o}$ sufrir- el delito. ${ }^{72}$

Por otra parte, la experiencia comparada demuestra que para acreditar la calidad de esta diligencia se debe desconfiar fuertemente de los reconocimientos posteriores, y toda la atención debería centrarse sobre el primer reconocimiento. En otras palabras, a lo que un juez de garantía o el adjudicador debería poner más atención, tanto para proteger las garantías como para valorar la calidad de la evidencia, es la forma precisa en que se realizó la primera diligencia de reconocimiento; en las siguientes el valor en el juicio debería ser, si es que alguno, muy limitado. Por ejemplo, si ya hubo reconocimientos previos respecto de un imputado, el valor del reconocimiento en la sala de audiencia debería ser, desde el punto de vista de la calidad para acreditar la participación, mínimo. $^{73}$

La explicación de por qué los reconocimientos sucesivos son peligrosos las da Steblay y son:

1. El resultado de los procesos sucesivos se basa en la familiaridad del testigo con el sospechoso, pero esa familiaridad se puede relacionar más con el primer reconocimiento que con el delito. El riesgo es que se genere un error cognitivo por la confusión de fuentes.

2. Además se puede generar un error cognitivo llamado "transferencia inconsciente" que en términos sencillos implica que luego del primer reconocimiento la memoria del testigo tiende a suplantar el rostro del verdadero responsable por el primer reconocido. ${ }^{74}$

3. Una simple deducción, el testigo detecta que el común denominador en los distintos reconocimientos es el sospechoso.

4. Ultimo factor, pero no menos importante, el del compromiso. El testigo tiene el compromiso de ser fiel a su propia decisión hecha en la primera identificación. $^{75}$

Por último, se suele argumentar que el problema de los reconocimientos es consustancialmente sicológico o por la forma en que se realiza la diligencia, y que no tiene relación con el modelo procesal penal vigente en un país, si este es inquisitivo o acusatorio. Sin embargo, un estudio de Wells, Ferguson y Lindsay, de 1981, concluyó que los sesgos y los riesgos de los reconocimientos erróneos se agravan en un modelo

\footnotetext{
${ }^{71}$ STEBLAY, "Maintaining the Reliability", cit. nota ${ }^{\circ} 56$, p. 645.

${ }^{72}$ STEBLAY, "Maintaining the Reliability", cit. nota ${ }^{\circ} 56$, p. 645.

${ }^{73}$ Así lo ha reconocido la jurisprudencia de Canadá, al sostener que si bien los reconocimientos en la sala de audiencias están permitidos, se debe reconocer que esas identificaciones pueden tener un muy bajo valor probatorio para probar que el acusado fue el autor. Véase, sentencia Hibbert [2002] 2 S.C. 445 (lo destacado agregado).

${ }^{74}$ Estos dos errores cognitivos tienen la similitud en cuanto que redireccionan la memoria del testigo a un nuevo sujeto, el sospechoso inocente.

${ }^{75}$ Véase, STEBLAY, "Maintaining the Reliability", cit. nota $\mathrm{n}^{\circ}$ 56, p. 649. Todo esto refuerza, una vez más, la necesidad de que el testigo no sepa que reconoció al verdadero sospechoso.
} 
adversarial, por la tensión que las partes le agregan a un proceso ya altamente desconfiable. ${ }^{76}$ En efecto, en ese estudio los testigos (incluidos víctimas) de los fiscales fueron sometidos a un fuerte contrainterrogatorio por parte del defensor. Sin embargo, antes del contrainterrogatorio la mitad de los testigos fueron "preparados" por la fiscalía en el sentido de advertirles que el defensor iba a tener una actitud antagónica y de confrontación, en otras palabras "que haría todo lo posible para desacreditar su testimonio". Esa preparación tuvo un impacto relevante y trascendental en los testimonios, básicamente porque les dio a los testigos mayor confianza en las identidades de los imputados reconocidos (la mitad de ellas incorrectas) y, por lo tanto, se obtuvieron mayores condenas -falsas condenas, pero condenas al fin y al cabo.

El estudio concluye que en el modelo adversarial el rol de las partes, las expectativas de ellas, la lógica de "juego" (donde hay que ganarle al adversario) también se trasladaron a las víctimas y testigos. Esa distorsión genera en los testigos "la tendencia de ubicación" y, por lo mismo, de asumir las expectativas y percepciones del rol que los presenta como "sujetos relevantes" para ganar la causa. El problema es que cuando la lógica de "querer ganar" se traslada a los testigos, para ellos, entonces, el resultado del caso no sólo se transforma en relevante desde su propia expectativa, sino que de las expectativas institucionales. En el estudio en comento esa motivación orientada a la parte resultó ser mucho más fuerte incluso que las instrucciones de ser justos y objetivos. En ese sentido, no deja de tener razón Frankel cuando sugiere que el modelo adversarial genera en los testigos y los peritos una "cynical mindset" con respecto a la objetividad del proceso. ${ }^{77}$ Por ello es importante que los jueces de garantía, pero también de juicio oral, estén especialmente atentos para identificar si existe algún indicio de compromiso adversarial en los testigos o en las partes -que exceda las reglas razonables del proceso- y que permitan desconfiar del reconocimiento.

\subsubsection{Reconocimientos mediante exhibiciones ("show-ups").}

Para Morales y Welsch, los reconocimientos mediante exhibiciones cara a cara pueden ser definidos como aquellos procedimientos de identificación en que "[dada] las circunstancias, se requiere mostrarle al testigo un sólo sujeto". ${ }^{78}$ Otra definición, quizás algo más completa, es la del Black's Law Dictionary, que los explica como "una identificación de la etapa de investigación, en virtud de la cual un sospechoso [imputado] es confrontado con un testigo o la víctima de un delito. A diferencia de una rueda de imputados o de un reconocimiento fotográfico, la exhibición es una confrontación uno vs. uno.". ${ }^{79}$ Lo primero que debe decirse, aunque suene algo obvio, es que las exhibiciones cara a cara son altamente sugestivas ${ }^{80}$ y tienen como resultado

\footnotetext{
${ }^{76}$ Véase, WELLS, Gary; FERGUSON, Tamara; LINDSAY, R. C., "The tractability of eyewitness confidence and its implications for triers of fact”, Journal of Applied Psychology Vol. N 66 (1981), pp. 688-696.

${ }^{77}$ Véase, FRANKEL, Partisan Justice, cit. nota ${ }^{\circ} 6$, p. 14 y ss.

${ }_{78}^{78}$ MORALES/WELSCH, El reconocimiento de imputados en Chile, cit. nota ${ }^{\circ} 57$, p. 51.

${ }^{79}$ Black's Law Dictionary, 8va Edición, 2004, p. 1413.

${ }^{80}$ Véase, específicamente sobre las exhibiciones, AGRICOLA, Barbara, "The Psychology of Pretrial Identification Procedures: The Showup is Showing out and Undermining the Criminal Justice System", Law \& Psychology Review Vol. N 33 (2009), pp. 125-137. En especial la autora se refiere a tres aspectos problemáticos de las exhibiciones, a saber, su contenido inherentemente sugestivo; el efecto sicológico que tiene la identificación mediante una exhibición en el adjudicador y las implicaciones constitucionales que tienen - o que deberían tener- las exhibiciones.
} 
CASTILLO, Ignacio. "Enjuiciando al proceso penal chileno desde el inocentrismo (algunos apuntes sobre la necesidad de tomarse en serio a los inocentes)."

un número relevante de falsas identificaciones y falsas condenas, en particular por el alto valor que los tribunales les asignan a esta diligencia. ${ }^{81}$ Por ello, como lo ha sostenido la doctrina comparada, las exhibiciones son, junto con los reconocimientos que se hacen en la sala de tribunales, las de menor credibilidad y las que más desconfianza deberían generar en el juez. ${ }^{82}$

Con todo, cabe peguntarse, como ha sido el tenor de este trabajo, si ellas pueden aportar un valor cognoscitivo al juicio y qué tipo de relación tienen con la garantía del debido proceso u otra que sugiera una preocupación desde el ámbito del control cautelar.

Respecto de la primera cuestión, cómo lo ha dicho la doctrina comparada, las exhibiciones no pueden simplemente ser un procedimiento desechado, porque en ciertas circunstancias excepcionales pueden ser necesarias y útiles. Pero, como lo ha reconocido alguna jurisprudencia norteamericana, su utilización debería ser reservada como última ratio y siempre cuando la detención del imputado sea casi inmediata a la comisión del delito (v.gr. cuando la víctima está en riesgo y su identificación se puede perder, ${ }^{83}$ cuando el imputado pudiera escapar y evadir una identificación, ${ }^{84}$ cuando el imputado es detenido en un momento muy inmediato después del delito ${ }^{85}$ o frente a la

\footnotetext{
${ }^{81}$ Véase, LEE, Jessica, "No Exigency, no Consent: Protecting Innocent Suspects from the Consequences of Non-Exigent Show-Ups", Columbia Human Rights Law Review Vol. N 36 (2005), pp. 755-799, p. 757. En el mismo sentido véase, AGRICOLA, "The Psychology of Pretrial Identification" cit. nota ${ }^{\circ} 80$, p. 127.

${ }^{82}$ Ello, porque en ambas situaciones se le da a la víctima una única opción -salvo que alguien crea que la víctima va confundir al imputado con el gendarme o con su abogado- y por lo mismo no hay control de las variables, además porque la forma de exhibición -al inicio de la investigación o en el juicio oralregularmente importa un medio altamente sugestivo y que potencialmente induce a una equivocación subconsciente. Lo paradójico de esto, al menos de los reconocimientos cara a cara es, como bien lo dice Hartman, que "a pesar de ser reconocido el hecho de que las identificaciones erradas ocurren más frecuentemente en los reconocimientos cara a cara, las policías las usan cada vez más seguido". Véase, HARTMAN, Rhiannon, "Why the Innocence Movement should focus on proscriptive pre-conviction measures instead of abolition of the Death Penalty", Richmond Journal of Law and the Public Interest Vol. 12, $\mathrm{N}^{\circ} 2$ (2009), pp. 163-187, p. 167. Dejando de lado la discusión sobre la pena de muerte que, al menos seriamente, en nuestro país no tiene lugar, es importante recalcar como lo dice el autor que el hecho de permitir que los policías hagan (cuando quieran) este tipo de reconocimientos no es sólo responsabilidad del Ministerio Público, sino que también de los jueces, que en general valoran estas diligencias sin utilizar seriamente mecanismos profilácticos como exigir una fundamentación excepcional para su realización -o valorarlas, en su contenido epistémico, con una aproximación mucho más crítica. Por lo mismo, es importante insistir en que ello no es sólo un problema del debido proceso o del derecho a defensa, es también un problema epistémico. Es decir, cuando un reconocimiento cara a cara, sin la necesaria justificación que legitime su excepcional utilización, pasa el cedazo del juez de garantía (la preparación del juicio oral) ello no debería ser óbice para que el adjudicador no sea especialmente crítico respecto de esa diligencia, en cuanto a su valor como inferencia que le sirva para arribar a la verdad, pudiendo incluso generar en el mismo una duda razonable acerca de la participación del imputado (y claramente la carga de la prueba, en particular sobre las razones excepcionales que ameritaron el proceso de exhibición, corresponden al Ministerio Público -o el querellante- y no al imputado).

${ }^{83}$ Stovall v. Denno, 388 U.S. 293 (1967), cit. por LEE, "No Exigency, no Consent", cit. nota n 81, p. 763.

${ }^{84}$ People v. Carrero, 801 N.E.2d 1084 (Ill. App. Ct. 2003) cit. por LEE, "No Exigency, no Consent", cit. nota $\mathrm{n}^{\circ} 81$, p. 763

${ }^{85}$ People v. Gordon, 76 N.Y.2d 595, 600 (1990) cit. por LEE, "No Exigency, no Consent", cit. nota $n^{\circ}$ 81, p. 763.
} 
posibilidad de la pérdida de evidencia relevante ${ }^{86}$ ). También se ha dicho que puede ser útil en ciertos casos para aprovechar la memoria reciente de la víctima o de los testigos o para permitir una investigación rápida y eficiente (poder descartar rápidamente a un sospechoso y seguir buscando en las inmediaciones). La ausencia de esa estricta inmediatez, como lo reconoce Agricola, reduce significativamente la credibilidad de la identificación y -lo que es relevante para evitar condenas erróneas- existen pocas protecciones que limiten los efectos devastadores de la sugestibilidad de esas exhibiciones. $^{87}$

Por lo mismo, debe siempre preferirse una forma menos sugestiva y peligrosa de identificación que la exhibición cara a cara. Si el imputado ya se encuentra en la unidad policial, por ejemplo, es simplemente intolerable realizar una exhibición cara a cara y, en ese caso, no puede sino considerarse aquella técnica de investigación como una forma deliberada de generar un escenario de sugestibilidad para intentar asegurar una identificación. ${ }^{88}$ Junto a ello, deben proscribirse todo tipo de situaciones que pueda aumentar deliberadamente la sugestibilidad de una exhibición, y que puedan ilegítimamente presionar a los testigos a creer que la policía tiene razones para aprehender a un sospechoso -y que por lo mismo inviten a una respuesta confirmativa. En este sentido, frases como "detuvimos al asaltante" o "espere acá, que le traemos al delincuente para que lo identifique" deben ser eliminadas de las exhibiciones. Por último $-\mathrm{y}$ lo que, aunque inusualmente, se ha dado en Chile- deben prohibirse exhibiciones donde el detenido aparece esposado junto a los policías que lo detuvieron, o donde previo a la realización de la exhibición se obligó al imputado a utilizar una ropa similar a la que la víctima había indicado como la ropa del agresor. ${ }^{89}$ En estos casos pueden existir problemas de garantías, pero el principal problema es sobre la calidad de la evidencia, por el poco valor cognoscitivo que le entrega al juicio.

\footnotetext{
${ }^{86}$ United States v. Rush, 248 F. Supp. 2d 1121, 1123 (M.D. Ala. 2003) cit. por LEE, "No Exigency, no Consent", cit. nota ${ }^{\circ} 81$, p. 763.

${ }^{87}$ Véase, AGRICOLA, "The Psychology of Pretrial Identification”, cit. nota $n^{\circ} 80$, p. 128. La autora, en este punto, cita el fallo de la Corte Suprema de Estados Unidos, en el caso Stovall v. Denno, donde declara que "las posibilidades de injusticias en [el] punto [de las exhibiciones] es grande, por la manera en las cuales se hacen frecuentemente las confrontaciones, y por la posibilidad que a menudo el imputado vea precluido su derecho de reconstruir lo que ocurrió y por lo mismo de obtener una completa instancia sobre la identificación en el juicio". Stovall v. Denno, 388 U.S. 293 (1967), p. 298. Lamentablemente, como ya lo advertimos, esa aproximación garantista de la Corte Suprema de Estados Unidos se ha ido desvaneciendo y perdiendo, rebajando con ello la protección de los imputados inocentes.

${ }^{88}$ Por lo mismo, y conforme lo destacado supra, si luego de ese reconocimiento se hacen otros, realizados de mejor forma, el tribunal debería restarle a ellos un importante valor como elemento de prueba para aceptar la proposición fáctica del Ministerio Público. De hecho, si luego la víctima o el testigo hacen un reconocimiento particularmente creíble del imputado en el propio juicio oral, un tribunal medianamente consciente de los problemas de los reconocimientos debería desconfiar fuertemente de la calidad que esa prueba pueda aportar en la decisión adjudicativa.

${ }^{89}$ Véase, AGRICOLA, “The Psychology of Pretrial Identification”, cit. nota $n^{\circ} 80$, p. 80. La autora cita, respecto de este punto, una interesante jurisprudencia de la Corte Suprema de Wisconsin, que en lo central indica que "Es importante que las exhibiciones no sean realizadas en lugares, o de una manera, que implícitamente transmitan a los testigos que el sospechoso es el culpable. Las exhibiciones conducidas en una estación policial, en carros policiales o con el sospechoso visiblemente esposado, todas llevan consigo inferencias de culpabilidad y por lo mismo deberían considerarse sugestivas... [También] es importante que el sospechoso sea exhibido al testigo una sola vez. Si un sospechoso es identificado, la policía no tiene ninguna razón para realizar posteriormente otros procedimientos de identificación. Por el contrario, si el sospechoso no es reconocido, él o ella no deberían ser presentados ante ese testigo en ninguna identificación subsecuente". State v. Dubose, 699 N.W.2d 582, 594 (Wis. 2005).
} 
CASTILLO, Ignacio. "Enjuiciando al proceso penal chileno desde el inocentrismo (algunos apuntes sobre la necesidad de tomarse en serio a los inocentes)."

Si bien en este caso algunas alegaciones se podrían realizar respecto de infracción de derechos fundamentales, lo cierto es que ello -como por lo demás lo ha sostenido la jurisprudencia norteamericana- tendría sustento únicamente respecto del debido proceso en términos generales, cuestión que no siempre ha sido así reconocido. ${ }^{90}$

Por lo mismo, junto al debate sobre las garantías, se debería reforzar en sede adjudicativa el control sobre las razones que tuvieron las policías para hacer este tipo de reconocimiento, determinar si estaban en una de las situaciones excepcionales que se han reconocido como posibles justificaciones para realizarlo, y si ello no es así restarle credibilidad al reconocimiento a fin de generar duda sobre la identificación. Dejar esta discusión únicamente en sede de control cautelar, además de insuficiente, es inadecuado, porque aún cuando alguien podría decir que en un caso de identificación con exhibición no hubo infracción de garantía, su valor probatorio (por la forma en que se originó) no es suficientemente idóneo -más allá de toda duda razonable- para corroborar la tesis acusatoria.

Para que los jueces puedan cumplir con esta función de adjudicación y valorar los reconocimientos, se requiere que ellos tengan toda la información necesaria para tomar la decisión. Por lo mismo, deben ser absolutamente estrictos en exigir que se realicen -y luego las partes lo presenten- los registros respecto de la hora de la identificación, la forma en que se practicó, la necesidad de hacerlo urgentemente, la individualización previa que había realizado la víctima, la ropa que el sujeto portaba, la distancia y el lugar preciso en que se encontraba el sospechoso y el sujeto que identificaba, en definitiva, todo lo que sea importante para tomar una adecuada decisión.

\subsubsection{Reconocimientos fotográficos.}

El reconocimiento fotográfico es, usualmente, el que se desarrolla al inicio de la investigación cuando la policía aún no tiene identificado a un imputado y espera que el testigo ocular, o la víctima, puedan reconocer a un sospechoso a partir de la exhibición de fotografías.

Esta diligencia es esencial que sea realizada por un administrador ciego, de modo que le sea imposible sugestionar al testigo respecto de quien debe reconocer, pero tampoco de confirmarle si su reconocimiento era o no el que se esperaba. Es más, aquello es tan crucial que se ha propuesto que los reconocimientos fotográficos sean realizados por programas automáticos que vayan desplegando fotografías de manera aleatoria y que además impidan que el administrador vea cuál foto es la que el testigo está viendo hasta que todo el procedimiento haya finalizado. ${ }^{91}$

\footnotetext{
${ }^{90}$ De hecho, si uno analiza la jurisprudencia comparada sobre el problema de las garantías en los reconocimientos advertirá que la mayoría de las discusiones se dan respecto de los reconocimientos en rueda, y no de las exhibiciones. Así, por ejemplo, las discusiones típicas son el derecho a poder contar con un abogado defensor, el derecho a no autoincriminarse en la medida en que se le obliga al sospechoso a participar en la diligencia, el derecho del defensor a poder "participar activamente" haciendo preguntas a los testigos y víctimas, etc. Salvo el derecho a negarse a participar, el resto no parecen poder aplicarse a los reconocimientos.

${ }^{91}$ Véase, en este sentido, la ley de North Carolina $\S 15 \mathrm{~A}-284.52(\mathrm{c})$.
} 
Polit. crim. Vol. 8, No 15 (Julio 2013), Art. 7, pp. 249 - 313.

[http://www.politicacriminal.cl/Vol_08/n_15/Vol8N15A6.pdf]

Existen, en todo caso, en la experiencia comparada seis importantes recomendaciones para los reconocimientos en fotografías:

1. Uso efectivo y adecuado de fotografías con sujetos similares al del sospechoso.

2. Una adecuada administración ciega de las fotografías.

3. Una adecuada y cuidadosa instrucción a los testigos, expresándoles expresamente que el sospechoso puede o no estar presente en las fotografías. Y ello debe quedar registrado.

4. Presentación secuencial y no simultánea de las fotografías. Registro de cada fotografía exhibida.

5. En principio evitar la "vuelta atrás" a mirar otra foto, evitar comparaciones y, si eso sucede, dejarlo adecuada y detalladamente registrado.

6. Una declaración registrada del grado de certeza del testigo en el momento de la identificación.

\subsubsection{Reconocimiento en rueda de imputados.}

Los reconocimientos en rueda de imputados se caracterizan porque al testigo ocular se le pide que identifique un posible autor del delito quien se encuentra entre un grupo de distractores. Como dice Wells, la psicología - preocupada de los temas legales- hace tiempo que ha reconocido el potencial efecto prejuicioso en estos procedimientos, y ello ha significado que el reconocimiento por testigos oculares -en especial en rueda de imputados- sea una de las áreas más estudiadas y mejor comprendidas en toda la psicología aplicada. ${ }^{92}$

Antes de abordar la discusión sobre la realización y el valor de los reconocimientos en rueda, existen dos aspectos que deben resolverse inmediatamente. El primero se refiere a la exigencia de la voluntariedad del imputado para someterse a este tipo de diligencias investigativas. El segundo, en cambio, al contenido y alcance del derecho del imputado a contar con un abogado defensor, o al menos a darle la oportunidad razonable de contactarse con uno antes de la realización de la misma.

Respecto de la primera cuestión, a saber, el derecho del imputado a rehusarse a participar en un reconocimiento en rueda de imputado, no parece necesario argumentar demasiado. En primer lugar, porque constitucionalmente el imputado tiene el derecho a no ser forzado a colaborar y fortalecer el caso de la persecución, sumado al respeto a la dignidad personal del imputado, que se afectaría si se le exige someterse a un tratamiento de identificación, como la rueda, sin su voluntad. En segundo lugar, porque aunque nuestro CPP no lo exprese, es evidente que del conjunto de normas que regulan la participación del imputado en la etapa de investigación, interpretadas axiológicamente, resulta evidente que el imputado tiene el derecho a no participar voluntariamente de un reconocimiento. ${ }^{93}$ En tercer lugar, la negativa del imputado a

\footnotetext{
92 Véase, WELLS, Gary; SMALL, Mark; PENROD, Steven, et al., "Eyewitness identification procedures: recommendations for lineups and photospreads", Law and Human Behavior Vol. 22, n 6 (1998), pp. 603-647, p. 604.

93 Así, por ejemplo, El Code of Practice (Code D) de la Police and Criminal Evidence Act inglesa, de 1989, prescribe la necesidad del consentimiento del imputado para someterse a un reconocimiento en rueda de imputado. Podría intentarse una interpretación distinta sobre todo a partir de las normas del CPP sobre pruebas caligráficas (art. 203) y exámenes corporales (art. 197) que prescriben que el juez puede autorizar -contra la voluntad del imputado- la diligencia. Creo, en todo caso, que esa respuesta sería
} 
CASTILLO, Ignacio. "Enjuiciando al proceso penal chileno desde el inocentrismo (algunos apuntes sobre la necesidad de tomarse en serio a los inocentes)."

someterse a esta diligencia -que debe respetarse- podría supone un hecho relevante dentro de la investigación, que luego el juez de garantía o el adjudicador pueden conocer (por ejemplo por medio de la declaración del funcionario a cargo de la diligencia) y respecto de la cual pueden sacarse inferencias negativas.

En cuanto a la segunda cuestión, a saber, el derecho del imputado a contar con un abogado defensor en la diligencia de reconocimiento en rueda de imputado, o al menos darle la oportunidad razonable para que pueda disponer de uno, la cuestión no es sencilla. Cabe distinguir, si se trata de una actividad de reconocimiento realizada una vez que el sujeto ya ha sido formalizado o requerido (causa judicializada) la cuestión parece pacífica: en ese caso el fiscal tiene la obligación de notificarle y comunicarle la diligencia al defensor y éste el derecho de participar en la misma. El problema más complejo se produce cuando la diligencia se desarrolla antes de la judialización de la causa, típicamente en el cuartel policial. En ese contexto, me parece que una interpretación orientada a la protección del derecho de defensa técnica del imputado, relacionada con la renuncia a abstenerse de cooperar con la investigación y voluntariamente someterse a la diligencia -que vimos en el párrafo anterior-supone la necesaria advertencia al imputado de su derecho a contar con un abogado defensor o al menos de darle un tiempo razonable para que pueda, si lo desea, contactarse con uno. Alguna jurisprudencia comparada lo ha resuelto en este sentido. ${ }^{94}$

Ahora, enfrentados a la cuestión sobre la forma de realización y la valoración que debe darse a esta diligencia, lo primero que debemos decir es que en estos procedimientos es absolutamente necesario que el funcionario policial a cargo del reconocimiento no conozca la identidad del verdadero sospechoso - que se cumpla con el requisito del administrador ciego. Se le debe advertir a la víctima o a los testigos, antes de practicar el reconocimiento, que el funcionario a cargo desconoce si el sospechoso se encuentra en la formación de la rueda e, incluso, que es posible que el autor puede o no estar presente, explicitándole a la víctima o al testigo que "ninguno de ellos" es una respuesta más que válida.

Por otra parte, los filtros o "señuelos" que componen la rueda deben ser al menos cuatro individuos (además del imputado) y deben ser escogidos de manera tal que se asemejen a la descripción que la víctima o los testigos dieron previamente (v.gr. edad, altura, contextura física, color de pelos y piel, vestimenta, etc.). Asimismo, en caso de que sea necesario realizar más de un reconocimiento con un testigo (v.gr. cuando son varios los imputados ${ }^{95}$ ), no pueden usarse los mismos señuelos en una nueva diligencia. Por

inadecuada en el caso de los reconocimientos por la propia naturaleza de la diligencia, donde la voluntad del imputado (y por lo mismo su disposición a la realización) es requisito sine qua non que la misma no resulte sugestiva y que no induzca inadecuadamente al testigo o la victima a un determinado resultado. Lo anterior, en todo caso, es sin perjuicio del valor que se pueda extraer de esa negación, y de la posibilidad de realizar otro tipo de reconocimiento, como el fotográfico ( $\sin$ que el testigo o la víctima sepan, evidentemente, que se trata de esa persona la que se negó al reconocimiento).

94 Así, por ejemplo, la Corte Suprema de Canadá, en la causa Ross (1989) 46 .C.C.C. (ed) 129 (S.C.C.), consideró ajustada a derecho la exclusión del resultado de un reconocimiento en que al imputado no se le había otorgado una oportunidad razonable para consultar con un abogado defensor.

95 Porque es pacífico que deberían estar prohibidos los reconocimientos donde participen más de un sospechoso, por el riesgo que con ello puedan aumentar los reconocimientos falsos, al menos que se aumente en el doble el número de señuelos. 
último, en caso de que existan múltiples testigos en el reconocimiento, estos deben participar individualmente, y luego quedar absolutamente separados del resto, para que no puedan comunicarse entre sí antes, durante y hasta que termine la diligencia. Asimismo, se debería asegurar que en cada reconocimiento se cambien las posiciones de los participantes de la rueda.

Se debería, además, instar a las grabaciones de los reconocimientos ${ }^{96} \mathrm{y}$, en especial, a un adecuado registro sobre el nivel de confianza que la víctima o el testigo señalaron al momento de escoger a un sospechoso. ${ }^{97}$ Por último, si el testigo o la víctima reconocen a un participante de la rueda, se les debe consultar explícitamente -y dejarlo registradosi a esa persona la habían visto anteriormente en otra oportunidad, como en una diligencia (v.gr. en una exhibición) o en los medios de comunicación. Lo importante es que, como lo ha dicho la comisión de la NYSBA, la no adopción de las policías de estas medidas debería ser un factor a considerar por los tribunales al momento de decidir la admisibilidad de las identificaciones $\mathrm{y}$, en nuestro caso, además, por los jueces adjudicadores para darle un valor inferencial relevante al medio de prueba. ${ }^{98}$ Lo anterior se podría justificar porque como nuestro sistema de adjudicación descansa sobre jueces profesionales, estos deberían ser particularmente escépticos -desde un punto de vista epistémico- a los reconocimientos que no cumplan con estas medidas.

Existen, por último, dos cuestiones adicionales que deberían generar en Chile una discusión pública relacionada con los reconocimientos de imputados. En primer lugar, la cuestión respecto de la admisibilidad de testimonios expertos que expliquen las dificultades cognitivas, de memoria o de sesgos, relacionadas con los reconocimientos. Este tipo de peritajes, se ha dicho, aportarían información relevante y pertinente a los adjudicadores, porque les permitirían valorar, en el caso concreto, si la ejecución de la diligencia de reconocimiento del imputado, a la luz de lo descrito por la ciencia contemporánea, puede o no considerarse riesgosa. Este debate ha sido extenso en Estados Unidos, muy marcado por el precedente Daubert, pero también por el hecho que la adjudicación la realizan sujetos legos que en general desconocen estos problemas. ${ }^{99}$ Ese estándar, como es habitual en la jurisprudencia norteamericana, ha

\footnotetext{
${ }^{96}$ En ese sentido, por ejemplo, la ley de North Carolina es estricta, en el artículo 15A-284.52 (b) (14), exige que los funcionarios policiales deben registrar en video las diligencias de reconocimiento, tanto en rueda como en fotografías, y en caso de no poder hacerlo debe entonces registrase en audio. Si no es posible registrarla en video, o ni siquiera en audio, el funcionario debe dejar una expresa constancia señalando las razones específicas por las cuales no pudo hacerlo.

${ }^{97}$ Este punto es central dentro de la diligencia de reconocimiento en rueda de imputados, y también en la que se realiza con fotografías. De hecho, a modo de ejemplo, la ley de North Carolina respecto de los reconocimientos, 15A-284.52 (b)(12), dispone expresamente que el funcionario a cargo de la diligencia debe pedirle al testigo que identifique "en sus propias palabras, el nivel de confianza que el testigo tiene que la persona identificada en la rueda es el autor del delito".

${ }_{98}^{8}$ Reporte de Comisión de la NYSBA, cit. nota ${ }^{\circ} 36$, p. 72.

${ }^{99}$ Como se sabe, la Corte Suprema de Estados Unidos, en Daubert v. Merrell Dow Pharmaceuticals 509 U.S. 579 (1993)], aplicando la regla $\mathrm{N}^{\circ} 702$ de las Federal Rules of Evidence fijó un test de admisibilidad para cualquier testimonio científico. La Corte indicó que un juez federal debe actuar como un "gatekeeper" al decidir qué evidencias científicas deberían ser admisibles y cuáles no. El juez debe evaluar las evidencias ofrecidas y determinar si acaso el razonamiento es científicamente válido y si el razonamiento puede ser aplicado en el caso concreto y, si eso es así, si acaso el testimonio experto propuesto es relevante para el caso y va resultar útil para el adjudicador. Esta decisión ha generado enormes dificultades interpretativas en el ámbito de los reconocimientos, sobre esto véase GOULD/VON HATTEN/STICKELS, "Reforming the use of eyewitness testimony", cit. nota n 62, p. 140.
} 
CASTILLO, Ignacio. "Enjuiciando al proceso penal chileno desde el inocentrismo (algunos apuntes sobre la necesidad de tomarse en serio a los inocentes)."

generado un enorme problema interpretativo en las Cortes inferiores, las que no han tenido una respuesta uniforme respecto de la cuestión de la admisibilidad del peritaje acerca de la memoria humana y en problemas de reconocimiento -aunque es preciso reconocer que la mayoría ha optado por rechazarlo. La razón sería aquella de evitar suplir la función del adjudicador. ${ }^{100}$

En nuestro sistema, dado que la adjudicación descansa sobre jueces profesionales y no en un jurado, me parece que uno pudiera ahorrarse esta discusión sí y sólo sí la Academia Judicial, en los cursos de formación y perfeccionamiento, contemple programas de capacitación a los jueces (tanto de garantía como de juicio oral) sobre los problemas de garantías y epistémicos de los diversos tipos de reconocimientos, a fin de que ellos puedan contar con toda la información relevante, incluyendo los últimos estudios científicos, para decidir adecuadamente los problemas que surgen en los procesos penales.

La segunda discusión que deberíamos tener en Chile es respecto a la necesidad de que los reconocimientos, en particular los en rueda y fotográficos, se desarrollen secuencialmente o de manera simultánea. En efecto, el hecho que un proceso de identificación se realice secuencialmente implica que los diferentes componentes de la rueda (el imputado y los señuelos) se deben ir presentando uno a uno ante la víctima o los testigos, de manera que ellos no tengan la posibilidad de optar, elegir ni comparar a quien finalmente van a identificar en el procedimiento (incluso no deberían tener la posibilidad de volver atrás o, si lo hacen, ello debería quedar expresamente registrado). En cambio el modo simultáneo, como su nombre lo indica, permite que se presenten todos los componentes de la rueda o el set fotográfico de manera conjunta, para que la víctima o el testigo puedan identificar - de la totalidad del grupo- a la persona que cometió el delito. ${ }^{101}$ Esta cuestión no es baladí porque un número relevante de estudios científicos han identificado dos consecuencias que surgen de la opción entre uno u otro método. Por un lado, los procedimientos simultáneos tienen la desventaja que mantienen un porcentaje todavía elevado de falsas identificaciones, en especial, porque la víctima o el testigo suele comparar y generar una opción marcada por los patrones de identificación que recordaba. Sin embargo, tienen también la ventaja que permiten a la víctima o a los testigos un mayor número de identificaciones correctas, es decir, permiten un mayor nivel de eficacia a la hora de identificar. En cambio, los mecanismos secuenciales tienen la gran ventaja que reducen de manera sustantiva las posibilidades de una falsa identificación, pero muestran que las víctimas y testigos suelen tener menor capacidad para identificar al responsable.

La discusión está abierta, cuál será nuestra preferencia como sociedad; un sistema que tienda a disminuir los errores de falsas identificaciones, aún cuando eso signifique un

\footnotetext{
${ }^{100}$ Véase, WISE, et al., "How to Analyze the Accuracy of Eyewitness", cit. nota ${ }^{\circ} 56$, pp. 452 y ss.

${ }^{101}$ Como lo dicen Lindsay, Pozzulo et al. "presentar a los testigos a un reconocimiento en rueda con todos los participantes a la vez (simultáneamente) permite, y posiblemente incentiva, el uso de juicios relativos. Cuando el autor está presente, esta aproximación puede ser efectiva desde que el autor del delito es más posible que ningún otro participante de la rueda que sea capaz de resaltar en la memoria del testigo respecto del autor. En todo caso, cuando el autor no está dentro del reconocimiento, la víctima igualmente va tender a identificar a uno, de hecho el miembro de la línea que más se asemeje a su memoria del autor." Véase LINDSAY/POZZULO/GRAIG et al., "Simultaneous Lineups, Sequential Lineups, and Showups", cit. nota n 67, p. 392
} 
mayor número de culpables no puedan ser identificados, o un proceso que tenga mayores posibilidades de errores en la condena, pero que sea a su vez más eficaz para identificar al responsable. Volvemos al debate del trade-off entre aumentar el número de falsas condenas o disminuir las falsas absoluciones. ${ }^{102}$

Por último, me parece importante recalcar que en los casos donde se realizó un reconocimiento se debe exigir un aumento en la evidencia que acredita el proceso de identificación. Se debe incentivar a que se cite a declarar al funcionario que realizó la detención, al que manejó el proceso de identificación (que, como ya dijimos, debe ser distinto) y el fiscal debería mostrar los videos y las fotos de los reconocimientos para que el tribunal pueda ver si efectivamente se cumplieron todos los requisitos, en particular si se dispuso de sujetos con similares características, incluso en las fotos que fueron utilizadas en el procedimiento. Esto no es sólo una responsabilidad de los fiscales o de los defensores, sino que es también una responsabilidad de los jueces, que deberían tener las herramientas para exigir esto. La herramienta podría ser la duda razonable, es decir, todo lo que no se prueba permite acrecentar la duda razonable. Esta es una respuesta posible, pero deberíamos pensar en ir más allá, o sea que los jueces tengan mayores prerrogativas, mayores facultades, incluso de poder salirse de la pasividad que el sistema hoy les impone. Pero ello no tiene, al menos por ahora, sustento normativo, así que no es más que un alegato de lege ferenda. En todo caso, los jueces deberían usar la facultad del artículo 329 del CPP, para preguntar todo lo necesario respecto del reconocimiento, para valorar adecuadamente el procedimiento y, con ello, acercarse más a la verdad.

\subsection{La prueba pericial y las condenas de inocentes.}

Según los datos que aportan las investigaciones realizadas por el inocentrismo la tercera causa de mayor impacto en la condena de gente inocente es la presentación, en el juicio oral, de evidencia científica parcial o fraudulenta y la deficiencia de ciertos peritos, que han servido de vínculo - erróneo- para relacionar a un imputado con un delito. ${ }^{103}$ Ello se explica, como lo veremos, por el propio modelo adversarial y por el excesivo uso de las pericias.

\footnotetext{
102 Véase, MEDWED, "Innocentrism”, cit. nota $n^{\circ} 9$, p. 1555, sostiene que "los grupos que en general critican los movimientos inocentristas, porque consideran que con las modificaciones que se pretenden aumentarán las posibilidades de falsos negativos, optarían por un sistema simultaneo más que uno secuencial". Varias de las comisiones institucionales que se han formado para diseñar políticas públicas respecto de las condenas erróneas han terminado por relevar esta misma situación, pero han optado por la necesidad que se encarguen mayores investigaciones empíricas. Así, v.gr. Reporte de la Comisión de la NYSBA, cit. nota $\mathrm{n}^{\circ} 36$, p. 64 y ss.

${ }^{103}$ Véase, AMERICAN BAR ASSOCIATION, Achieving Justice: Freeing the Innocent, Convicting the Guilty, report of the ABA Criminal Justice Section's Ad Hoc Innocence Committee to Ensure the Integrity of the Criminal Process, 2006, pp. 48 y ss. En parte este es el fenómeno de la llamada "junk science", término que originalmente fue popularizado por Huber, inicialmente para criticar las admisibilidades de peritajes con poca credibilidad, principalmente en juicios por responsabilidad civil, véase, BERNSTEIN, David, "Junk Science in the United States and the Commonwealth", Yale Journal of International Law, Vol. N ${ }^{\circ} 21$ (1996), pp. 123-182, donde el autor analiza interesantes casos de Australia, Nueva Zelandia, Inglaterra y Canada; y GIANNELLI, Paul, "The Abuse of Scientific Evidence in Criminal Cases: The Need for Independent Crime Laboratories”, Virginia Journal of Social \& the Law Vol. N 4 (1997), pp. 439-478.
} 
CASTILLO, Ignacio. "Enjuiciando al proceso penal chileno desde el inocentrismo (algunos apuntes sobre la necesidad de tomarse en serio a los inocentes)."

Stella, cuando se refiere a la prueba pericial en el contexto de un modelo adversarial, sostiene lo siguiente:

\begin{abstract}
"la ola de procedimientos judiciales que relacionan a la ciencia y la tecnología en los últimos decenios ha provocado «un espectacular aumento del número y tipo de expertos, llamados a participar de los procesos» (expertos en ingeniería, economía, medicina, epidemiología y toxicología, biología molecular, siquiatría, sociología, estadística, geología, lingüística, filosofía y sociología de la ciencia); la estructura antagonista del proceso penal ha dado lugar a una auténtica «cultura de parte» de los testimonios de los expertos, la cual hace difícil separar los hechos de la opiniones científicas, las opiniones de las puras conjeturas, las cuestiones de hecho de las elecciones de valores". 104
\end{abstract}

Este aumento del uso de la pericia, que no sólo se da en Italia, se explica por el valor que suele asignarse a este tipo de prueba para la resolución de un caso, lo cual incentiva a las partes a tratar de justificar sus proposiciones mediante la acreditación de un tercero, el "perito", quien en razón de su profesión, conocimiento o experticia da una explicación científica a la teoría del caso de la parte que lo presenta. Ello, en todo caso, se da con mayor fuerza tratándose de los modelos adversariales, porque ahí los abogados tienen mayores incentivos para intentar ganar y presentar una mejor evidencia que el competidor. En otras palabras, existe un fuerte estímulo a la sobre utilización de la prueba pericial -y no necesariamente la más idónea- como un elemento relevante para persuadir al adjudicador. Esto lo resume acertadamente Haack al sostener que el "sistema legal [el modelo adversarial] a menudo obtiene menos de la ciencia de lo que la ciencia podría darle: los abogados están motivados, por las exigencias de su profesión, a buscar expertos que estén dispuestos a sombrear o seleccionar la evidencia como lo demanda el caso, y ello puede incentivar a maverick, marginales o expertos menos que honestos, en el lucrativo negocio de los peritajes", ${ }^{105}$ quienes están más que disponibles a presentar pericias con metodologías criticadas por la comunidad científica o, por lo menos, no completamente consensuadas.

Por lo mismo, como dice Lorusso, es imprescindible que los jueces mantengan una aproximación de marcado escepticismo frente a este tipo de evidencia, en particular si se trata de peritajes que no corresponden a ciencias formales. Porque, como bien lo explica este autor
"no existe un método que, aunque sea diligentemente seguido, permita arribar a un conocimiento cierto y seguro [...] las ciencias empíricas o reales, de hecho, no ofrecen un método idóneo para asegurar la absoluta certeza o verdad de las conclusiones, que más modestamente pueden ser representadas como altamente probables". 106

\footnotetext{
${ }^{104}$ Véase, STELLA, Federico, Giustizia e Modernità, La protezione dell'innocente e la tutela delle vittime, Milano: Giuffrè Editore, 3a Edición, 2003, p. 32 (lo destacado en el original). Stella cita, en las partes resaltadas, a JASANOFF, Sheila, Science at the Bar: Law, Science, and Technology in America, trad. it. La scienza davanti ai giudici. La regolazione giuridica della scienza in America, trad. a cargo de Marta Graziadei, Milano: Giuffré; 2001, pp. 80 y ss.

${ }^{105}$ Véase, HAACK, Susan, "Inquiry and advocacy, fallibilism and finality: culture and inference in science law”, Miami Law Research Paper Series Vol. № 2 (2003), pp. 205-214, p. 208.

106 Véase, LARUSSO, Sergio, "La prova scientifica", en: GAITO, Alfredo (Dir.), La Prova Penale, Torino: Utet Giuridica, 2008, p. 299. Obviamente el autor excluye de este razonamiento a las ciencias
} 
Polit. crim. Vol. 8, No 15 (Julio 2013), Art. 7, pp. 249 - 313.

[http://www.politicacriminal.cl/Vol_08/n_15/Vol8N15A6.pdf]

Como bien lo ha sostenido Duce, respecto de nuestra realidad, los riesgos de la práctica de sobre utilizar las pericias son

"[p]or una parte... generar un proceso de sustitución del trabajo judicial por el trabajo de expertos (...) [d]e otra... por el impacto que produce este tipo de prueba en el juzgador, especialmente tratándose de pericias en disciplinas de difícil comprensión para no especialistas." 107

Si bien comparto con Duce su preocupación por la excesiva utilización de la prueba pericial y la falta de control sobre ella, agregaría a sus propuestas de solución, como lo veremos infra, otras cuestiones más sistémicas enfocadas a la imparcialidad y al control general de la calidad de los laboratorios, peritos y peritajes.

En primer lugar, entonces, una preocupación debería enfocarse hacia los peritos y los peritajes, que deben ser controlados en serio si lo que se pretende es evitar, en la mayor medida de lo posible, condenar a un imputado fácticamente inocente. En este caso, como también lo ha expresado Duce, debe analizarse al perito y el peritaje cuidadosamente desde una doble vía, por un lado el respeto a las garantías y derechos fundamentales $\mathrm{y}$, por otro, por su propio valor como evidencia. ${ }^{108}$ Lo interesante, en todo caso, es que en este último aspecto debe todavía distinguirse entre el valor epistémico que se puede analizar en sede cautelar (desde la perspectiva de la admisibilidad de la pericia o del perito en cuanto a la relevancia de la pericia), como el que necesariamente deben realizar los jueces adjudicadores. Esta última diferencia es trascendental para comprender bien la complejidad que se relaciona entre los peritajes y las condenas de los imputados "f inocente".

Lo primero es establecer criterios claros para definir la inadmisibilidad de ciertos peritos o de ciertas pruebas periciales que lejos de colaborar en el esclarecimiento de los delitos, confunda o simplemente prejuzgue al adjudicador y termine por facilitar la condena de inocentes. En este punto, entonces, debe existir una especial preocupación por no admitir al juicio junk science o tener los medios para detectarla en el juicio oral y evitar valorarla excesivamente. En parte, esta preocupación la ha explicitado recientemente la Corte Suprema de Florida, que ha dicho que los "jueces (de tribunales y cortes) deben aplicar de una manera prudente el estándar de Frye para desechar la ficción científica y la "ciencia basura" de los hechos". ${ }^{109}$

formales o analíticas (lógica, matemática, geometría, etc.) en las cuales la verdad de la premisa se transmite a la conclusión, de manera que no es lógicamente hipotizable que, siendo verdadera la primera, no resulte verdadera la segunda.

107 Véase, DUCE, Mauricio, "Admisibilidad de la prueba pericial en juicios orales", en: ACCATINO SCAGLIOTTI, Daniela (Coord.): Formación y valoración de la prueba en el proceso penal, Santiago: Ed. Abeledo Perrot, 2010, p. 48. Duce, en todo caso, agrega como tercera razón el aumento de los costos para el sistema.

${ }^{108}$ Véase, DUCE, “Admisibilidad de la prueba pericial en juicios orales”, cit. nota n 107 , pp. 53 y ss. Respecto de la protección de garantías y derechos fundamentales no me detendré mayormente, porque comparto lo señalado por Duce, y remito al lector a revisar su trabajo, del todo interesante. En cambio, me abocaré a otros temas, no tratados por el autor, que me parecen de la mayor trascendencia para revisar el estado actual de las pericias en Chile.

${ }^{109}$ La referencia de la Corte Suprema de Florida por el estándar Frye, a diferencia del posterior Daubert [citado supra] es una muestra más de que muchas cortes norteamericanas continúan privilegiando el 
CASTILLO, Ignacio. "Enjuiciando al proceso penal chileno desde el inocentrismo (algunos apuntes sobre la necesidad de tomarse en serio a los inocentes)."

El mayor riesgo de los peritajes se presenta, como dice Huff, en aquellos casos en que se han desarrollados innovadoras técnicas de investigación -pericias- que fueron generadas bajo condiciones de emergencia creadas por un cierto pánico social -real o ficticio- donde los investigadores "expertos" desarrollan nuevas técnicas de investigación para enfrentar esa emergencia, técnicas que no han sido ni validadas ni testeadas, pero que supuestamente tendrían la capacidad de esclarecer los delitos y darle protección a la sociedad. Este fenómeno ha sido ampliamente investigado en los delitos sexuales de menores, donde han proliferado pericias que permitirían identificar situaciones de abuso a partir de la interpretación de dibujos o por el comportamiento de los menores al realizar juegos simulados con muñecos. También se ha podido observar situaciones similares en casos de terrorismo o de explosivos, donde suele justificarse conclusiones periciales con discutidas técnicas de investigación. ${ }^{110}$

Con todo, además de lo ya dicho, en nuestro país la situación en relación a los peritos y los peritajes es extraordinariamente compleja. Además de la libertad absoluta de las partes para presentar pericias (todo ello en un marco de poco control sobre las cualidades y méritos de los peritos, y además de la pertinencia y metodologías de las pericias) se debe sumar el hecho que los peritos institucionales tienen, respecto del Ministerio Público, una posición de organismos auxiliares, lo cual los pone en una situación de parcialidad difícilmente aceptable. Peor aún, los laboratorios de criminalística dependen directamente de las policías, lo cual los ubica en una situación institucional aún más interesada, porque ya no sólo tienen un sesgo de parcialidad con el Ministerio Público, sino que muchas veces con la misma policía que desarrolla la investigación. Esto último, como se comprenderá, es particularmente riesgoso si lo que se quiere es evitar condenar a un imputado inocente.

La experiencia comparada ha demostrado que en un número importante de los casos en que se condenó erróneamente, la principal causa de esa condena de un inocente fue que en los juicios habían participado peritos que eran expertos del Estado, y con una relación muy directa y estrecha con el órgano de persecución. Por ejemplo en Canadá se

estándar de "generalmente aceptado" de ese precedente, por sobre el complicado criterio que aparece de la Regla N 702 de las Federal Rules of Evidence. Sobre esto véase, AMERICAN BAR ASSOCIATION, Achieving Justice, cit. nota $\mathrm{n}^{\circ} 103$, pp. 48 y ss. El fallo Daubert fue luego seguido por General Electric Co. v. Joiner, 522 U.S. 136 (1997) y Kumho Tire Co. v. Carmichael, 526 U.S. 137 (1999). En términos sencillos, y luego de la modificación de la regla federal $\mathrm{N}^{\circ} 702$ en el año 2002, la admisibilidad ahora requiere que el testimonio del perito (1) se base sobre suficientes datos y hechos (2) sea el producto de creíbles principios y métodos, y (3) sea creíblemente aplicado a los hechos del caso. En el caso Daubert, la Corte ha dicho que para diferenciar entre la buena y la mala ciencia, los jueces deberían, pero no tienen la obligación de hacerlo, considerar cuatro factores: testeabilidad; revisiones de pares y las publicaciones; ratio de error y los estándares para su desarrollo; y la aceptación general del peritaje. Junto a ello, lo que creo constituye un error, la Corte sostuvo en ese fallo que las herramientas tradicionales del modelo adversarial, a saber, el contrainterrogatorio, la evidencia contradictoria, el estándar de prueba, seguramente servirían de guías para que el jurado no se confundiera con la ciencia basura. Sobre esto véase, sin autor, "Admitting Doubt: A new Standard for Scientific Evidence", Harvard Law Review Vol. $\mathrm{N}^{\circ} 123$ (2010), 2021-2042, p. 2023.

110 GROMETSTEIN, Randall, "Wrongful Conviction and Moral Panic, National and International Perspectives on Organized Child Sexual Abuse", en: HUFF; KILLIAS, Wrongful Conviction, cit. nota ${ }^{\circ}$ 10 , p. 21 y ss. Sobre el incremento del uso de expertos y de ciertas "experticias" en las investigaciones de delitos sexuales, muchas de ellas con importantes deficiencias metodológicas y cuestionable función de sustituir, validar o darle credibilidad al testimonio de la víctima, véase, GERSHMAN, "Child Witnesses", cit. nota $n^{\circ} 67$, pp. 603 y ss. 
realizaron dos investigaciones públicas en casos emblemáticos de condenas erróneas, entre las observaciones que las comisiones realizaron, ambas apuntaron al trabajo forense, identificando problemas en la contaminación de la evidencia y la falla del perito de comunicarle -al fiscal y al juez- los límites de su peritaje, es decir, hasta donde la ciencia apoyaba las conclusiones de su tesis. Pero eso no queda sólo ahí, en otra comisión de investigación, se identificó que un patólogo voluntariamente exageró las causas de muerte y, consultado sobre ello, señaló que él creía que su objetivo era jugar un rol adversarial como parte de la persecución y lograr que "el caso se viera bien [para el Ministerio Público]". 111

En este punto, la National Academy of Sciences, en su reporte sobre las ciencias forenses "Strengthening Forensic Science in the United States: A Path Forward", sugirió que se debería remover, de los laboratorios criminales, el control administrativo de las agencias de persecución, ello porque "la mejor ciencia es conducida en un escenario científico en oposición a un escenario de persecución. Porque los expertos científicos a menudos son guiados en su trabajo por la necesidad de contestar particulares respuestas relacionadas con ciertas partes de un caso particular, y por lo mismo a veces enfrentan presiones para sacrificar una metodología apropiada por la necesidad de conveniencia [de quien pretende luego presentarlos al juicio]."112

Esta relación de parte entre los laboratorios y la persecución penal no es nueva, de hecho existe abundante literatura crítica respecto de ello ${ }^{113} \mathrm{y}$, además, alguna

${ }^{111}$ Véase, KAUFMAN, Fred, Commission on Proceedings Involving Guy Paul Morin, 1998, pp. 12351239; LESAGE, Patrick, Report of the Commission of Inquiry into Certain Aspects of the Trial and Conviction of James Driskell, 2007, pp. 121-22 finalmente GOUDGE, Stephen, Inquiry Into Pediatric Forensic Pathology In Ontario 538-42 (2008). Situación no muy distinta a la que se ha denunciado en Estados Unidos, en particular si se atiende a lo expresado por Garrett, quien ha sostenido que "son cada vez más común los casos donde los oficiales de la persecución [no necesariamente fiscales] sostienen que la evidencia física coincide con la sangre, el pelo, etc., cuando en verdad no es así, generalmente empleando 'junk science' para darle credibilidad a falsos testimonios. Los expertos de los laboratorios a menudo trabajan muy juntos con los persecutores durante las investigaciones criminales y comparten su credibilidad. Esos laboratorios han sido cada vez más criticados por su falta de independencia, sus cuestionables estándares científicos, falta de auditorías externas y casos en que derechamente han cometido fraude en los peritajes científicos. véase, GARRETT, Brandon, "Innocence, Harmless Error, And Federal Wrongful Conviction Law", Wisconsin Law Review Vol. N 35 (2005), pp. 35-114, p. 95. Sería interesante saber cómo en Chile, donde una parte importante de los laboratorios pertenecen a la persecución penal (LABOCAR y LACRIM), otro -el Servicio Médico Legal- si bien no tiene ese nivel de relación, su manera de trabajar es bastante cercana al Ministerio Público y, por último, los laboratorios (o centros de pericias sicológicas) privados pagados por el Ministerio Público, se puede justificar la independencia de los peritos, si ninguno de ellos tienen ningún nivel de escrutinio y de accountability respecto de sus peritajes con el resto de la comunidad científica.

${ }^{112}$ National Academy of Sciences, Strengthening Forensic Science In The United States: A Path Forward, cit. en: GIANNELLI, Paul, "Independent Crime Laboratories: The Problem of Motivational and Cognitive Bias", Utah Law Review Vol. N 2 (2010), pp. 247-266. En el mismo sentido Garrett, quien destaca que "hace tiempo un grupo importante de académicos y de científicos están reclamando un sistema de revisión de pares de los laboratorios forenses policiales [y privados] para evitar los incentivos, o la mala fe, propios de la junk science y que generan condenas de inocentes". Véase, GARRETT, "Innocence, Harmless Error", cit. nota n 111, p. 105.

${ }^{113}$ Sobre esto véase los trabajos GIANNELLI, Paul, "The Abuse of Scientific Evidence", cit. nota n ${ }^{\circ} 103$; JONAKAIT, Randolph, "Forensic Science: The Need for Regulation", Harvard Journal of Law \& Technology Vol. N 4 (1991), pp. 109-191, pp. 160 y ss.; MOENSSENS, Andre, "Novel Scientific Evidence in Criminal Cases: Some Words of Caution", The Journal of Criminal Law \& Criminology Vol. $\mathrm{N}^{\circ} 84$ (1993), pp. 1-21; Citados en: GIANNELLI, "Independent Crime Laboratories", cit. nota ${ }^{\circ} 112$, ver nota 4 . 
CASTILLO, Ignacio. "Enjuiciando al proceso penal chileno desde el inocentrismo (algunos apuntes sobre la necesidad de tomarse en serio a los inocentes)."

jurisprudencia inglesa lo ha así valorado negativamente. ${ }^{114} \mathrm{Y}$ la razón de esa alerta es que en el sistema adversarial se han detectado diversos sesgos que directamente implican a los laboratorios y a los peritos, a saber, el sesgo motivacional, ${ }^{115}$ el sesgo cognitivo, asociado al efecto rol; ${ }^{116}$ el prejuicio contextual; ${ }^{117}$ el prejuicio de confirmación; ${ }^{118}$ y el prejuicio reconstructivo. ${ }^{119}$

Sin perjuicio de lo anterior, y aún asumiendo que el sistema chileno es problemático, los jueces no pueden simplemente rechazar las pruebas periciales y abstenerse de considerarlas en sus valoraciones, ello es obvio. Pero tampoco deben desconocer que la forma en que se relacionan las instituciones $-\mathrm{y}$ los peritos- con los encargados de la persecución penal, ha sido fuertemente criticada por la comunidad científica internacional y por quienes se preocupan de las condenas de inocentes. Por lo mismo, lo único que creo que los jueces pueden hacer legítimamente es ser especialmente cautelosos y escépticos de la "idoneidad" del perito y el peritaje, y no darla por supuesta sólo por el hecho de que provienen de una institución pública. A diferencia de lo que sugiere el sentido común, en orden a que los peritos institucionales tendrían mayor credibilidad e imparcialidad que los peritos privados, la experiencia comparada da cuenta que ello no es verdad, y que lo más relevante, (además de someter la metodología y los resultados de la pericia a un fuerte proceso de contradictoriedad donde además deberían participar los jueces), es la transparencia con la cual esas instituciones y peritos exponen sus trabajos, su participación en la comunidad científica nacional, el sometimiento metodológico de sus pericias a estrictos protocolos certificados y la acreditación que tengan. También es importante que en Chile se empiece a discutir, como parte del derecho a defensa versus el derecho de privacidad, la

\footnotetext{
114 "Los expertos forenses pueden volverse partes. El sólo hecho que la policía [fiscales] busquen su asistencia puede crear una relación entre las policías [fiscalías] y los expertos. Y el carácter adversarial del proceso tiende a promover esta relación. Los científicos forenses empleados por el gobierno pueden comenzar a ver su función como la de ayudar a las policías [fiscales]." $R$ v. Ward, [1993] 96 Crim. App. 1, 68 (U.K.).

${ }^{115}$ Es el más conocido de los sesgos, y que se refleja en la idea del árbitro del que se dice está sesgado porque quiere que una de las partes gane. En materia penal, cuando el perito del Ministerio Público (que asume el rol de parte de la persecución) tiene dudas, sus resultados siempre van a perjudicar al imputado.

${ }^{116}$ La percepción del rol que cumplen en el sistema (apoyar al Ministerio Público en la persecución) puede generar incluso un sesgo subconsciente, que tiende a generar - en casos de dudas- un apoyo al Ministerio Público.

${ }^{117}$ Esto se da cuando la información externa influencia la decisión del perito. Los conocimientos externos alteran las expectativas del perito lo que a su vez afecta la percepción del mismo. Dicho de otra manera, cuando un perito recibe más información de la necesaria para su pericia, pero que puede generarle un sesgo respecto del resultado del mismo, ello puede afectar las expectativas y la percepción de su trabajo. Esto en Chile se da masivamente -y para variar sin control- en aquellos casos en que los fiscales le envían la carpeta fiscal completa al perito para que realice su peritaje (típicamente en casos sexuales, de imputabilidad u otros) donde obviamente el perito asume una posición completa respecto del caso (el sujeto es culpable) y ello genera un sesgo en la calidad de su pericia.

${ }^{118}$ En este caso se trata de la tendencia a testear una hipótesis buscando instancias que las confirman más que buscando instancias potencialmente falsas. En Chile esto se incentiva con la práctica de enviar las carpetas de investigación, pero además con las conversaciones entre los policías y los peritos, o el fiscal y los peritos, donde los primeros explican sus teorías y líneas de investigación, de manera tal que generan un fuerte incentivo de sesgo de confirmación en el perito.

119 Para revisar todos los casos y las explicaciones de las citas precedentes, véase, GIANNELLI, "Independent Crime Laboratories", cit. nota ${ }^{\circ} 112$, pp. 250 y ss. Además el autor ejemplifica con casos reales que se han generado en Estados Unidos de peritos que consistentemente apoyaron -a veces con teorías y metodologías más que cuestionables- a la fiscalía.
} 
Polit. crim. Vol. 8, No 15 (Julio 2013), Art. 7, pp. 249 - 313.

[http://www.politicacriminal.cl/Vol_08/n_15/Vol8N15A6.pdf]

densidad de la obligación de registro y descubrimiento de las comunicaciones entre los fiscales y los peritos (v.gr. work products), que en general tienen que ver con anticipaciones de resultados, informes preliminares u otras comunicaciones previas al informe final, ello puede ser esencial para la defensa de un imputado inocente.

Con todo, el objetivo de este capítulo fue simplemente evidenciar que el sistema chileno tiene un peligroso vacío respecto de la prueba pericial. El modelo liberal de admisibilidad que se aplica en la práctica, que básicamente exige un mínimo de experticia (o cualificación) respecto del experto, y que el peritaje sea mínimamente relevante para el caso, conlleva un riesgo muy alto de que se estén presentando pericias con poco rigor metodológico y con resultados escasamente creíbles. Si a ello se le suma una excesiva relación de dependencia o de parcialidad entre las instituciones que realizan las pericias y el ente persecutor, además de una débil contradictoriedad del sistema y una más o menos sencilla recepción por parte de los jueces, no es fácil imaginarse el escenario (según lo demuestra la información comparada) más que propicio para que se condene gente fácticamente inocente. ${ }^{120}{ }^{121}$

Por último, es interesante compartir que tanto la resolución como los informes que emitió el Comité Ad Hoc del ABA, para asegurar la integridad del proceso criminal, explicitaron cuatro recomendaciones que debían observarse en los temas materia de evidencia forense:

1. Los laboratorios que practiquen pericias criminales deberían estar registrados y acreditados. Junto a ello, los expertos médicos que participan de esas pericias también deberían estar acreditados. Los examinadores de las pericias deberían estar certificados. Se deberían estandarizar los procedimientos y publicarlos. En particular la publicidad debiera buscar darles validez a esos procedimientos, mejorar su credibilidad en la comunidad científica y medir los tiempos de los análisis. $^{122}$

2. Dotar de mayores recursos a los laboratorios criminales, pues la falta de recursos adecuados genera demora en la justicia, afecta el desarrollo de la investigación, implica un excesivo costo en la libertad de las personas privadas de libertad, afecta la credibilidad del sistema y puede incluso afectar la seguridad pública en la medida que un culpable puede estar libre, mientras el inocente se mantiene preso.

3. Mejorar la cantidad y calidad de los expertos de la defensa, en particular de los que no tienen recursos. Y las pericias se tiene que enfocar a diversos aspectos, y

\footnotetext{
${ }^{120}$ En sentido similar, véase, RING, Sinead, "Due Process and the admission of expert evidence on recovered memory in historic child sexual abuse cases: lessons from America", The International Journal of Evidence \& Proof Vol. N 16 (2012), pp. 66-92, p. 67 y s.

${ }^{121}$ Muy crítico con el modelo adversarial, y los efectos que tiene respecto de la parcialidad de las pericias y su poca credibilidad, véase, EDMOND, Gary; SAN ROQUE, Mehera, "The Cool Crucible: Forensic Science and the Frailty of the Criminal Trial", Current Issues in Criminal Justice Vol. N²4 (2012), pp. 51-68. A juicio de los autores, las así llamadas "protecciones del juicio" como el contrainterrogatorio, la opinión contradictoria de expertos y los criterios de admisibilidad son absolutamente ineficientes para asegurar la credibilidad de la pericias, para otorgarle un alto valor epistémico y como mecanismos para evitar la condena de un inocente.

${ }^{122}$ Estas recomendaciones son, a su vez, ampliamente concordantes con las recomendaciones del reporte National Academy of Sciences, analizado infra. Actualmente en Nueva York la ley requiere que todos los laboratorios sean acreditados.
} 
CASTILLO, Ignacio. "Enjuiciando al proceso penal chileno desde el inocentrismo (algunos apuntes sobre la necesidad de tomarse en serio a los inocentes)."

no solamente a cuestiones periféricas, como exámenes de asistentes sociales y sicólogos.

4. Mejorar la competencia y el entrenamiento de los abogados para conocer las particularidades de las cuestiones científicas. ${ }^{123}$

Por otra parte, la Comisión de la NYSBA propuso diversas reformas diseñadas para el levantamiento y preservación de las evidencias, las cadenas de custodia, mejorar el acceso de la defensa a la evidencia forense, entre otras. ${ }^{124}$

Por último, no veo razones para oponerse -a modo de lege ferenda- a que en determinados casos, en especial aquello de alta complejidad y donde existe una contradictoriedad en las pericias, el juez de garantía pueda disponer la realización de un peritaje por un perito seleccionado por el órgano jurisdiccional. De hecho, en sistemas más adversariales que el nuestro esto está pacíficamente regulado (aunque en la práctica no se utilice en exceso) y se les permite a los jueces, en determinados casos, contar con mayor información epistémica para tomar su decisión. Así, por ejemplo la regla 706 de las Federal Rules of Evidence de Estados Unidos permite que sea el juez, de oficio o a petición de partes, quien determine la realización de una pericia por un perito apuntado por el tribunal. ${ }^{125}$ Es cierto que las partes pueden proponer un determinado perito, pero finalmente el juez puede seleccionar a quien estime más idóneo. Lo importante es que el perito acepte. Luego, una vez realizado el peritaje -que debe ser debidamente informado a las partes- éstas pueden citar al perito o, incluso, el juez hacerlo por su propia iniciativa, quedando siempre las partes con la facultad de contrainterrogarlo, o sea, de poder contradecir su idoneidad como perito, la metodología utilizada en su peritaje y la confiabilidad de las conclusiones de su trabajo. De hecho en nuestro sistema, por ejemplo, si esa decisión la toma el juez de garantía, durante la etapa de investigación, y luego no son los jueces encargados de la adjudicación los que ordenan la pericia, no me parece que se pueda decir que existe una afectación a la imparcialidad del tribunal ni que con ello se afecte el debido proceso. Por el contrario, es una medida que, siendo

\footnotetext{
123 Sobre este punto, véase, GIANNELLI, Paul, "Forensic Science and the ABA Innocence Report", Southwestern University Law Review Vol. N 37 (2008), pp. 993-1007. El texto, luego de observar las recomendaciones del reporte del ABA, hace un interesante trabajo comparativo entre estas recomendaciones y las $A B A$ Standar on DNA Evidence, en especial en lo que se refiere al manejo de esa evidencia por los laboratorios y como mejorar sus prácticas.

${ }^{124}$ Reporte de la Comisión de la NYSBA, cit. nota ${ }^{\circ} 36$, pp. 96 y ss.

${ }^{125}$ Rule 706. Court-Appointed Expert Witnesses: (a) Appointment Process. On a party's motion or on its own, the court may order the parties to show cause why expert witnesses should not be appointed and may ask the parties to submit nominations. The court may appoint any expert that the parties agree on and any of its own choosing. But the court may only appoint someone who consents to act. (b) Expert's Role. The court must inform the expert of the expert's duties. The court may do so in writing and have a copy filed with the clerk or may do so orally at a conference in which the parties have an opportunity to participate. The expert: (1) must advise the parties of any findings the expert makes; (2) may be deposed by any party; (3) may be called to testify by the court or any party; and (4) may be cross-examined by any party, including the party that called the expert. (c) Compensation. The expert is entitled to a reasonable compensation, as set by the court. The compensation is payable as follows: (1) in a criminal case or in a civil case involving just compensation under the Fifth Amendment, from any funds that are provided by law; and (2) in any other civil case, by the parties in the proportion and at the time that the court directs - and the compensation is then charged like other costs. (d) Disclosing the Appointment to the Jury. The court may authorize disclosure to the jury that the court appointed the expert. (e) Parties' Choice of Their Own Experts. This rule does not limit a party in calling its own experts.
} 
Polit. crim. Vol. 8, No 15 (Julio 2013), Art. 7, pp. 249 - 313.

[http://www.politicacriminal.cl/Vol_08/n_15/Vol8N15A6.pdf]

excepcional, puede perfectamente ayudar a mejorar la calidad cognoscitiva de la información con que cuente el adjudicador.

\subsection{Declaraciones Previas, Negociaciones y Preparación de los Testigos.}

Como lo vimos en el capitulo introductorio, otro de los factores comunes que se repite en las condenas de imputados " $f$ inocentes" es el inadecuado trabajo de las entrevistas o declaraciones previas, y la preparación que las partes realizan de testigos, víctimas y peritos antes del juicio oral. Ello porque la prueba testimonial y pericial sigue teniendo un impacto trascendental en la formación de la convicción de los jueces, y su incorrecto manejo puede implicar un enorme impacto en la información que reciben los jueces. Como lo anunciamos al inicio ello puede implicar un abismo entre la evidencia completa y la evidencia sintetizada. ${ }^{126}$ Por lo mismo, se trata de medios de prueba respecto de los cuales los jueces deberían ser particularmente rigurosos a la hora de determinar su veracidad y credibilidad, a fin de identificar el valor probatorio que puedan tener para lograr corroborar o no la tesis acusatoria. Las entrevistas o declaraciones previas, y la preparación de testigos, víctimas y peritos, constituyen un aspecto de especial preocupación en el ámbito comparado, en particular en aquellos países que tienen un modelo adversarial de persecución penal. ${ }^{127}$ Lamentablemente ello no ha ocurrido en Chile, donde estos puntos siguen estando absolutamente desregulados y con escaso desarrollo jurisprudencial; por lo mismo no existen los limites y las prohibiciones necesarias que sirvan para mejorar el mérito cognoscitivo del proceso.

Como ha sucedido con los otros temas del presente artículo, la literatura nacional no ha enfrentado el tema de las entrevistas previas y la preparación de los declarantes, antes y durante el juicio oral, con la profundidad que sería deseable. La doctrina ha mantenido una actitud pasiva para enfrentar analíticamente este problema, no ha identificando la importancia que tiene para la búsqueda de la verdad del proceso, no ha diseñado los

\footnotetext{
${ }^{126}$ Respecto de la prueba testimonial, en nuestra literatura, Coloma, Pino y Montecinos, señalan que "la información disponible en los procesos judiciales es generada recurriendo a diversos mecanismos, sin perjuicio de lo cual, las declaraciones formuladas por testigos se encuentran entre las que suelen ejercer mayor influencia en los jueces para efectos de elegir un determinado curso de acción en los litigios que deben resolver." Véase COLOMA, Rodrigo; PINO, Mauricio; MONTECINOS, Carmen, "Fundamentación de sentencias judiciales y atribución de calidad epistémica a las declaraciones de testigos en materia Procesal Penal", Revista de Derecho de la Pontifica Universidad Católica de Valparaíso Vol. XXXIII (2009), pp. 303-344, p. 304 y s. Sin perjuicio de lo interesante y novedoso que resulta el estudio, principalmente para conocer el razonamiento sobre la relevancia y la calidad epistémica que los tribunales le asignan a la prueba testimonial, hubiese sido interesante haber profundizado sobre el impacto de la preparación de los testigos por los intervinientes, los mecanismos profilácticos usados por los jueces para evitar que ello exceda lo "ético" y la implicancia en la valoración del testimonio cuando se aprecia una situación irregular. Sobre la complejidades éticas de la preparación de los testigos, lo que el autor define como uno de los más difíciles dilemas éticos que regularmente deben enfrentar los abogados véase, APPLEGATE, John, “Witness Preparation”, Texas Law Review Vol. N 68 (1989), pp. 277-352, p. 281.

${ }^{127}$ Damaška, por ejemplo, a propósito de los testigos -y en parte de los peritos- llama la atención sobre la inconveniencia de que ellos sean considerados "pertenecientes" a las partes, que deban ser pagados por las partes y que sean preparados antes de sus apariciones al tribunal expuestos a "preguntas prácticas" anticipando el escenario de un contrainterrogatorio. DAMAŠKA, Evidence Law Adrift, cit. nota n ${ }^{\circ}$ 6, p. 76-77.
} 
CASTILLO, Ignacio. "Enjuiciando al proceso penal chileno desde el inocentrismo (algunos apuntes sobre la necesidad de tomarse en serio a los inocentes)."

controles que desincentiven malas prácticas, ni menos ha propuesto sanciones cuando se compruebe una incorrecta conducta. ${ }^{128}$

Las entrevistas o declaraciones previas, que son aquellas que los testigos o las víctimas entregan durante la etapa de investigación al Ministerio Público y a la policía -y en menor medida a la defensa-, son trascendentales para el desarrollo de la investigación y el esclarecimiento de los delitos. Ellas constituyen una pieza de investigación indispensable para que el organismo persecutor pueda orientar la investigación hacia un resultado exitoso. Sin embargo, y como lo hemos descrito en el capítulo sobre la visión de túnel, constituyen también uno de los factores de mayor incidencia en la condena de imputados inocentes. Las razones de esto son variadas, van desde el exceso de celo con el que pueden laborar las policías o los fiscales, el interés del propio testigo o víctima en diseñar su declaración de modo de alterar la responsabilidad del imputado, el interés del testigo o la víctima de empatizar con la pretensión institucional personificada por el fiscal o el policía o, en los casos más extremos - pero no infrecuentes-, para obtener algún beneficio o recompensa a cambio de una declaración en contra del imputado.

En todos estos casos las posibilidades de una condena errónea aumentan porque, obviamente, el tribunal recibirá una información distorsionada/alterada de la realidad, lo cual afecta su capacidad de alcanzar un resultado que corresponda con la verdad. Es evidente, por otra parte, que muchas de estas situaciones son difícilmente gestionables en especial aquella donde el propio testigo o la víctima decide modificar su testimonio para alterar (agravar o disminuir) la responsabilidad penal del imputado. Sin embargo, los estudios del inocentrismo han demostrado que la forma en que actualmente se desarrollan las declaraciones previas - muchas veces reservadamente entre el fiscal, asistente de fiscal o la policía y el testigo o la víctima- influyen consciente o inconscientemente en que se vaya moldeando el relato de la manera que más favorezca

\footnotetext{
${ }^{128}$ Una excepción a ello, aunque todavía muy tímida, lo constituye el texto de Santelices, quien identifica una diferencia entre preparar a los testigos e inducir o hacer que el testigo altere la verdad. Según el autor, preparar a un testigo "...implica, probablemente, verificar que este se encuentre realmente al tanto de la porción de la información que aportará al juicio, verificar que recuerda aquellos detalles que nos interesa queden en conocimiento del juez, verificar con el su destreza o habilidad para declarar verbalmente ante un tribunal y, en su caso, prepararle para enfrentar dicha situación y, por cierto, poner acento en la porción de información que favorece mi versión de los hechos... [1] a versión inducir al testigo a mentir o a que altere la verdad, no resulta apropiada a un sistema de justicia democrático, basado en la buena fe procesal, e implica ciertamente la comisión de un delito". SANTELICES, Fernando, "Contradicción, Imparcialidad e Inmediación en la Ley de Enjuiciamiento Civil Española. Algunos problemas para la consolidación de estos principios en la práctica”, Ius et Praxis Año 18, № 1 (2012), p. 211. La diferencia planteada por el autor, en materia penal, es ciertamente insuficiente, porque justamente un inadecuado proceso de preparación tendiente a verificar que el testigo se encuentra realmente al tanto de la porción de información que aportará al juicio, en verificar que recuerda detalles y verificar sus destrezas para declarar, y en su caso prepararlo para hacerlo, se encuentra el germen de buena parte de las malas prácticas. El autor citado, en la página 221, sostiene que un testigo al declarar puede, conscientemente, omitir cierta información "que pueden resultar perjudicial para su postura" (destacado agregado). Me imagino que el autor está pensando sólo en sede civil, porque ese razonamiento en materia penal, más aún si se trata de un testigo del Ministerio Público, sería insostenible, pues supone conscientemente ocultar información que puede ser fundamental para que el tribunal arribe a una decisión ajustada a la verdad, lo que significa aumentar la posibilidad de condenar a un inocente. Si bien muchas de las conductas tratadas en este capítulo, como en el paper en general, podrían incluso ser subsumidas en el delito del artículo 269 bis y ter del Código Penal, me parece que, por el momento, podemos prescindir de su análisis para igualmente desarrollar la tesis del trabajo.
} 
Polit. crim. Vol. 8, No 15 (Julio 2013), Art. 7, pp. 249 - 313.

[http://www.politicacriminal.cl/Vol_08/n_15/Vol8N15A6.pdf]

a la parte. En general en las declaraciones previas de las víctimas y de los testigos el defensor del imputado no participa de ella, lo cual encierra un ámbito de reserva y secreto que es dañino en el contexto de la persecución penal. Similar situación puede suceder con los testigos de la defensa, lo que también es criticable, pero es cuantitativamente menos relevante en el sistema.

Todo esto se ve aún más agravado por el hecho que la práctica, incluso jurisprudencial, ha entendido que la obligación de registro (arts. 227 y 228 del CPP) se satisface con la sola trascripción de esas declaraciones en un papel, que luego es firmada por quien la realizó. Ello es insuficiente, como se comprenderá, porque permite que la misma se vaya trasformando en la redacción de un relato, de una historia, que es trabajada y consensuada entre el declarante y quien transcribe, a modo de ir formando una teoría del caso armónica con el conjunto del resto de la evidencia.

Ciertamente se podría decir que en un sistema adversarial una buena defensa debería también entrevistarse con la víctima y con los testigos, tomarle una declaración y con ello revertir ese espacio de reserva y complicidad entre los organismos de persecución y la víctima y los testigos. Pero esa respuesta es insuficiente. En primer término por una cuestión práctica, la defensa (en especial la pública) no tiene los recursos humanos ni materiales para poder hacer una investigación exactamente paralela a la del Ministerio Público. Además que ello sería, socialmente, muy costoso. Pero, aunque lo pudiera hacer, la experiencia comparada demuestra que ello es en muchos casos inútil, pues el modelo adversarial genera un prejuicio de identidad en las partes que las incentiva a mirar a la contraparte como antagónicas, como enemigos $\mathrm{y}$, por lo mismo, a reafirmar su posición con la parte con la que se sienten más afines.

Lo relevante de esta situación es que las declaraciones previas, cuando se toman de la manera ya expresada -como la trascripción de un relato o de una historia armónica con una teoría del caso que va armando la parte-, generan un fuerte impacto en la finalidad cognoscitiva del juicio, y no sólo porque los jueces son incapaces de identificar la diferencia entre el relato completo y el relato sintetizado (menos si asumen una posición pasiva, de observador) sino porque la técnica de litigación del contrainterrogatorio también resulta insatisfactoria para poder manifestar inconsistencias e incongruencias en el relato del testigo. De hecho, lamentablemente, en nuestro modelo procesal penal es cada día más común que los testigos revisen, varias veces antes del juicio oral, como quien se aprende una parte del guión de una obra de teatro, la declaración que deben luego reproducir ante el tribunal. Y su mayor capacidad de memoria será proporcionalmente inversa al número de preguntas que se le hagan en el interrogatorio y en el contrainterrogatorio.

En este sentido, la doctrina comparada ha empezado a discutir cada vez más seriamente la necesidad de enfrentar esta situación y adoptar las medidas profilácticas (de garantías, pero también epistémicas) para asegurar no sólo el respeto de las garantías del imputado, sino también la finalidad de determinar la verdad del juicio oral. En este sentido una buena herramienta es convocar, al menos en ciertos casos, frente a ciertas víctimas o testigos, al abogado de la contraparte para que pueda participar de la declaración, tomar sus propias notas y, eventualmente, realizar sus propias preguntas. Como ello no siempre es posible y, quizás, en algunos casos tampoco deseable, una alternativa diversa sería registrar en formato video o audio toda la declaración de la 
CASTILLO, Ignacio. "Enjuiciando al proceso penal chileno desde el inocentrismo (algunos apuntes sobre la necesidad de tomarse en serio a los inocentes)."

víctima y del testigo, de modo que ello le permita a la contraparte conocer la completitud de la declaración, y no sólo lo que quedó registrado en la trascripción. De hecho, ello incluso podría ser utilizado en el juicio oral, conforme la norma del artículo 332 del CPP (bastaría sólo con trascribir completamente la declaración, aunque nada impediría escuchar una parte del audio específico), para refrescarle la memoria o, mejor aún, manifestar inconsistencias entre la declaración presentada en el juicio oral y la que se dio en su oportunidad. Indudablemente esto sería una adecuada medida para prevenir las condenas de inocentes.

Mención aparte debe hacerse, en todo caso, con otros testigos, informantes o coimputados que declaren a cambio de algún tipo de recompensa. Así, por ejemplo, considérese un co-imputado que decide declarar en contra de un imputado, como parte de un acuerdo con el Ministerio Público para poder optar a una salida alternativa o para acceder a un procedimiento autoincriminatorio. $\mathrm{O}$ un testigo que decide declarar en contra de otro imputado, por ejemplo, para obtener una mejor ubicación en un recinto carcelario (recuérdese que en delitos cometidos al interior de la cárcel Gendarmería puede asumir el rol de organismo auxiliar de la persecución) o, por último, un informante policial que decide declarar en contra de un imputado para evitar ser perseguido penalmente en otros delitos. Todos estos son casos que ocurren más frecuentemente de lo que uno se imagina y que deben ser controlados a la brevedad. ¿Deben estos testimonios ser prohibidos y excluidos del juicio oral? La primera tentación es decir que si, porque ellos podrían afectar el derecho a la defensa, la presunción de inocencia y el debido proceso del imputado. Me temo, sin embargo, que tomar esa decisión a todo evento es un error, porque en algunos casos la información que puede aportar el testimonio de ese testigo, además de sincera, puede ser de un elevado valor epistémico, útil para que el tribunal alcance la verdad de los hechos. ¿Qué se debe hacer? Nuevamente debemos distinguir.

En el caso de que el testimonio incriminador provenga de un co-imputado, el tribunal debería inmediatamente tener una aproximación escéptica de la validez del mismo y exigir, al menos, tres cosas: por una parte que exista un completo descubrimiento del fiscal respecto de todas las negociaciones y acuerdos adoptados con el co-imputado, si ello significó una reducción de la pena, el ofrecimiento de alguna salida alternativa o un procedimiento de simplificación procesal, y si esa negociación se realizó antes o después de la declaración, si el ofrecimiento incluía la obligación de declarar en el juicio oral, etc.; en segundo lugar, si no es posible que concurran los defensores de todos los otros co-imputados a la declaración del imputado, al menos que la misma se registre en un formato que permita su reproducción íntegra y completa; tercero, el tribunal debe asegurarse que el testimonio presentado por el co-imputado sea corroborado por otra prueba objetiva presentada por el ente persecutor.

En el caso de los informantes y otros testigos con algún tipo de interés, en cambio, los jueces deberían exigir un completo descubrimiento respecto del testigo y de la negociación con el fiscal o con la policía (incluido Gendarmería). La exigencia de descubrimiento, en este caso, debe ser tan alta que incluya, al menos, las siguientes cuestiones: a) el completo registro de condenas, de SAF (Sistema informático del Ministerio Público) y del Kardex policial o la ficha de la cárcel del testigo; b) cualquier acuerdo, promesa, inducción o beneficio que el Ministerio Público, la policía o 
gendarmería le hubiese ofrecido al testigo, sea que lo haya cumplido o lo vaya a cumplir; c) el completo y total registro de las conversaciones o declaraciones previas que el testigo hubiera prestado, en un formato que permita su reproducción completa; d) todos los otros casos en que el informante o el testigo testificó o se hubiese ofrecido para testificar, sea para el Ministerio Público o para un organismo auxiliar; e) cualquier información relevante que pueda afectar la credibilidad del testigo. Como se puede apreciar, este estándar se podría aplicar -con ciertas correcciones-a los conocidos casos de los "testigos sin rostros", siempre y cuando se acepte la legalidad de los mismos.

En definitiva, si bien la situación de las declaraciones previas es compleja, me parece que es necesario comenzar a prestarles la mayor atención y mejorar las medidas de prevención para evitar que el modelo adversarial que hoy se ha ido asentando en Chile termine por distorsionar la finalidad del proceso, y que genere más condenas erróneas de las que queremos.

Por otra parte, la preparación de los testigos y peritos antes del juicio oral ha sido, también, uno de los aspectos de mayor preocupación para los académicos y los Colegios de Abogados (Bar Associations) norteamericanos, porque los abogados -fiscales, defensores y abogados en general- lo consideran como parte esencial del ejercicio de la profesión, y como una etapa básica de una adecuada representación. ${ }^{129} \mathrm{Y}$, en general, la mirada que se tiene de ese fenómeno no es del todo tranquilizadora. ${ }^{130}$ Hay autores que se refieren a la preparación de los testigos y peritos como uno de los oscuros secretos del proceso penal adversarial, ${ }^{131}$ y otros no dudan en calificarlo derechamente como el aspecto más sucio de la litigación. ${ }^{132} \mathrm{Y}$ esto es así porque la preparación de un testigo puede ser una herramienta útil y necesaria para ayudar a que recupere y recuerde una reconstrucción verídica de los hechos, pero también puede distorsionar la memoria del testigo y producir una falsa reproducción de los hechos, que es la que le llega al tribunal. ${ }^{133}$ También, desde la perspectiva epistémica, la preparación inadecuada de un testigo puede ser dañosa para la búsqueda de la verdad. ${ }^{134}$

La primera distinción que uno debería realizar es que, en general, la doctrina y la jurisprudencia anglosajona reconocen que preparar el testimonio de un testigo no es per

129 FLOWERS, Roberta, "Witness Preparation: Regulating the Profession's 'Dirty Little Secret"”, Hastings Constitutional Law Quarterly Vol. № 38 (2011), pp. 1007-1028, p. 1008.

${ }^{130}$ Altman considera -la preparación de testigos y peritos- como "el centro de un conflicto inherente al sistema adversarial". Y esa posición crítica, a juicio del autor, se da porque "por un lado, uno le debe a su cliente la obligación de una representación celosa -por lo que uno busca que los testimonios beneficien la causa de su cliente lo más posible. Por el otro lado, uno tiene la obligación de franqueza para con el tribunal - por lo que uno debe buscar la verdad y la justicia. Y, a veces, los intereses del cliente y la verdad colisionan". Véase, ALTMAN, James, "Witness Preparation Conflicts", Litigation Vol. N ${ }^{\circ} 2$ (1995), pp. 38-68 (pp. no continuas), p. 38.

${ }^{131}$ Véase, APPLEGATE, "Witness Preparation", cit. nota n ${ }^{\circ} 126$, pp. 279 y ss.

${ }^{132}$ Véase, FLOWERS, Roberta, "What you see is what you get. Applying the appearance of impropriety standard to prosecutors", Missouri Law Review Vol. N 63 (1998), pp. 699-766, p. 740.

${ }^{133}$ Algo muy distinto a lo que sucede cuando uno lee, por ejemplo, la literatura suiza sobre el mismo tema. Así, por ejemplo, Killias señala, refiriéndose a la preparación de los testigos -ni siquiera al entrenamiento- que "en Suiza la preparación de los testigos y peritos antes de una declaración está fuertemente prohibida, y no hay "testigos de la fiscalía" ni "testigos de la defensa", sino que sólo individuos que contribuyen y asisten al tribunal a buscar la verdad". Véase, por todos, KILLIAS, Martin, "Wrongful Convictions In Switzerland", en: HUFF/KILLIAS, Wrongful Conviction, cit. nota $\mathrm{n}^{\circ} 10$, $\mathrm{p}$. 142.

${ }^{134}$ Véase, FLOWERS, “Witness Preparation”, cit. nota n 129, p. 1009. 
CASTILLO, Ignacio. "Enjuiciando al proceso penal chileno desde el inocentrismo (algunos apuntes sobre la necesidad de tomarse en serio a los inocentes)."

se inapropiado o ilegal, en la medida en que se haga con estricto apego a las reglas éticas y de adecuado comportamiento profesional; otra cosa es, en cambio, "entrenar" un testimonio, lo cual es completamente inapropiado, para cualquiera de las partes. Esta distinción puede apreciarse ya en la jurisprudencia norteamericana que en Geders $v$. United States sostuvo que sobre el abogado existía una prohibición de influenciar inapropiadamente en el testimonio de un testigo. ${ }^{135} \mathrm{Sin}$ embargo esta diferencia, que a primera vista parece obvia y sencilla, en la práctica se revela como una cuestión bastante más compleja y difícil de resolver. ${ }^{136}$

La preocupación sobre la preparación de los testigos se ha retomado fuertemente en el último tiempo porque -además de las siempre vagas e imprecisas razones éticas- varios estudios han demostrado que el modelo adversarial (aquel que se ufana de tener un juez pasivo) es extremadamente ineficiente en controlar en el juicio oral los sesgos que ese entrenamiento genera. En otras palaras, la técnica de litigación que Wigmore ${ }^{137}$-algo exageradamente- denominaba la mejor herramienta inventada para descubrir la

${ }^{135}$ Geders v. United States, 425 U.S. 80, 90 n.3 (1976). El problema, como lo revela Flowers, es que la Corte no define lo que podría considerarse una "influencia inapropiada", quedando ella entregada a la completa arbitrariedad de las partes, y luego de los jueces. Véase, FLOWERS, "Witness Preparation", cit. nota $\mathrm{n}^{\circ} 129$, p. 1010.

${ }^{136}$ En general los Códigos de Ética norteamericanos prohíben a los abogados presentar evidencia falsa, aconsejar o asistir a un testigo a prestar un testimonio falso, fraudulento o perjurio. Véase Model Rules of Professional Conduct, reglas 3.3 (a)(4) (1983) ("A lawyer shall not knowingly... offer evidence that the lawyer knows to be false."); Id. en R. 3.4 (b) ("A lawyer shall not . . falsify evidence, counsel or assist a witness to testify falsely, or offer an inducement to a witness that is prohibited by law."); véase también el Model Code Of Presponsibility DR 7-102(A)(4) (1980) ("In his representation of a client, a lawyer shall not... [k]nowingly use perjured testimony or false evidence."); Id. en DR 7-102(A)(6) ("In his representation of a client, a lawyer shall not... [p] articipate in the creation or preservation of evidence when he knows or it is obvious that the evidence is false."); id. en DR 7-102 (A)(7) ("In his representation of a client, a lawyer shall not... [c]ounsel or assist his client in conduct that the lawyer knows to be illegal or fraudulent."). Una aproximación crítica a la regulación de la preparación de los testigos en el $A B A$ Model Rules of Professional Conduct, véase FLOWERS, "Witness Preparation”, cit. nota n 129, p. 1010 y ss.

${ }^{137}$ Según señalaba Wigmore, el contrainterrogatorio es la mejor herramienta legal jamás inventada para descubrir la verdad. Con razón Damaška desconfía de esa frase, para quien, incluso con las mejores intenciones, el contrainterrogador puede hacer que incluso testimonios creíbles puedan fácilmente mostrarse como desconfiables, e información clara puede volverse confusa. Véase DAMAŠKA, Mirjan, "Presentation of Evidence and Factfinding Precision", University of Pennsyvania Law Review Vol. N ${ }^{\circ}$ 123 (1975), pp. 1083-1106, p. 1094. Una crítica similar en ID., Evidence Law Adrift, cit. nota n 6, p. 79. Siguiendo con Damaška, uno podría decir que sin la información sobre la preparación de un testigo, un contrainterrogador difícilmente podría lograr desvirtuar ese testimonio, más aún si, como explican los manuales de litigación, una de las primeras "técnicas" que se enseñan en el contrainterrogatorio es la, así llamada, "no salir a pescar", o sea no preguntar si no se sabe antes la respuesta. Sin embargo, pocos conocen que el mismo Wigmore mostraba cierta desconfianza con esta herramienta cuando expresaba que "un abogado puede hacer cualquier cosa en el contrainterrogatorio... Él puede, y es verdad, hacer más de lo que quiere hacer; Él... puede hacer que la verdad aparezca como mentira" Véase, WIGMORE, John Henry, Evidence in trials at Common Law, Boston, Toronto: Little Brown (1970), p. 32. Y es por ello, por el poder del contrainterrogatorio de distorsionar la verdad, que Wigmore reconoce la necesidad que sea controlado. Y aun cuando el contrainterrogatorio puede ser una buena herramienta, pues puede ser un adecuado recurso para desacreditar a un testigo mentiroso, ha demostrado ser bastante ineficiente cuando el testigo honestamente se equivoca. También crítico respecto del valor del contrainterrogatorio, y en especial de su capacidad (en un modelo adversarial) para descubrir la verdad, véase, TARUFFO, Michele, La semplice verità. Il giudice e la costruzione dei fatti, Roma - Bari: Editorial Laterza, 2009, p. 110. 
verdad, ${ }^{138}$ a saber, el contrainterrogatorio, se muestra ineficiente cuando un testigo ha sido "inadecuadamente" preparado. Y ello por una razón muy sencilla, porque las preparaciones del juicio oral en general se hacen una vez que la audiencia de preparación ya se realizó, ergo, no hay obligación de registro y descubrimiento sobre esa actividad pero, además, porque por su propia naturaleza se hacen en un ambiente de reserva, donde hay confianza mutua por el sesgo de representar una misma parte, tener un mismo objetivo y buscar un mismo resultado. ${ }^{139}$ En ese contexto, la contraparte se encuentra absolutamente desnuda para poder generar un adecuado contrainterrogatorio, así de simple.

Y si bien el problema del entrenamiento a los testigos es algo que afecta indistintamente a ambas partes, la experiencia comparada da cuenta que la mayor preocupación debería ser puesta en las conductas de los fiscales, por una razón obvia, son lo que más testigos deben presentar en el juicio para ser interrogados. ${ }^{140}$ Pero además, porque los fiscales (a diferencia de los defensores) tienen para la ciudadanía (para las víctimas, testigos y peritos) un estatus diferente, son los abogados que representan los intereses colectivos y, por lo mismo, suelen ser mirados como altamente creíbles y dignos de confianza. De hecho, la experiencia comparada da cuenta de que respecto de los fiscales muchas veces el testigo (incluso uno desinteresado con el resultado del juicio) puede intentar adecuar o morigerar levemente su testimonio justamente en términos de lo que él cree que el fiscal quiere escuchar. Por el temor de defraudar a una autoridad pública. ${ }^{141}$

Por lo mismo, es importante ir generando una preocupación sistémica sobre la preparación de los testigos y peritos porque, por ejemplo, aquella es una instancia más

\footnotetext{
${ }^{138}$ En nuestra literatura Vial comparte esa opinión, y sostiene que el contrainterrogatorio representaría en el proceso penal chileno una herramienta todavía insuficientemente comprendida y aplicada. Véase, VIAL, Pelayo, "El derecho a confrontación con declaraciones de un juico anulado en el marco del proceso penal", Política Criminal Vol. 6, $\mathrm{N}^{\circ} 12$ (2011), pp. 448-473, p. 450. Sin perjuicio de no compartir el optimismo del autor respecto de esta técnica de litigación, ella es, indudablemente, necesaria en cualquier sistema que pretenda reconstruir los hechos respetando el debido proceso. Porque además de tener alguna capacidad de mejorar la calidad de la información que pueden recibir los jueces, permite que las partes puedan confrontar la prueba presentada por la contraparte y ejercer una legítima contradicción (derecho de defensa). Y, por lo mismo, aunque sea a modo de excursus, no se puede sino estar de acuerdo con las conclusiones del artículo del autor -aunque yo lo vincularía más con la exigencia epistémica de reconstruir la verdad del proceso- respecto al derecho de las partes para poder confrontar a los testigos o peritos con sus declaraciones prestadas en un juicio declarado nulo. La discusión que, en todo caso, todavía tendría algún sentido es si esa confrontación pueda estar justificada en la norma del artículo 332 ó 334 del CPP, o bien -como es mi opinión- mediante la regla del inciso segundo del artículo 336 del mismo cuerpo legal. Con todo, es evidente que si en el primer juicio el sujeto dijo A, y en el segundo dice $Z$, el Tribunal Oral del nuevo juicio oral debe conocer esa contradicción, que seguramente le servirá para verificar o refutar la coherencia del testimonio y la correspondencia de la afirmación de hechos motivo de la acusación.

${ }^{139}$ Una de las cuestiones que se suele insinuar en la litigación chilena, pero que no se ha podido ratificar, es que las partes, incluyendo a los fiscales, incluso preparan a los testigos a medida que se va generando el juicio, es decir, a medida que avanzan los testimonios. Las partes eventualmente continuarían preparando a sus testigos a medida que se van descubriendo "cabos sueltos" o "dudas razonables" durante el juicio. De ser cierto esa situación, de ocurrir en alguna oportunidad, ello debería ser fuertemente sancionado por las instituciones.

${ }^{140}$ En el caso chileno esto podría ampliarse a los querellantes y, en especial, a los casos en que estos por el forzamiento de la acusación asumen la responsabilidad de la persecución.

${ }^{141}$ Véase, GERSHMAN, Bennett, "Witness Coaching by Prosecutors", Cardozo Law Review Vol. № 23 (2002), pp. 829-863, p. 839.
} 
CASTILLO, Ignacio. "Enjuiciando al proceso penal chileno desde el inocentrismo (algunos apuntes sobre la necesidad de tomarse en serio a los inocentes)."

que fértil para quien quiera usar el modelo adversarial para un fin distinto al de ser una herramienta para descubrir la verdad, sino que, por ejemplo, para manipular la verdad en orden a asegurar una falsa condena o conseguir una falsa absolución. ${ }^{142}$ Segundo, porque a estas alturas deberíamos tener conciencia -que no me parece que exista- sobre lo verdaderamente propenso al error judicial del modelo adversarial como hoy funciona en Chile. Tercero, y lo más grave de todo, porque esa diferencia entre preparar y entrenar a un testigo no es reconocida por los intervinientes (ni siquiera por los jueces, que son los que adjudican) y a veces los jueces se impiden a las partes indagar en el juicio oral respecto de la forma en que se ejecutó la preparación de un testigo o perito, básicamente porque se desconoce cómo ciertos factores cognitivos, como la memoria, lenguaje y la sugestión pueden influir, sutil pero efectivamente, en el testimonio de un testigo, la víctima o un perito. ${ }^{143}$

Lamentablemente el estilo de preparación de los juicios orales que se ha ido consolidando en Chile -en especial respecto de las víctimas y testigos- es en gran medida un reflejo de la planificación de un escenario de conflicto y no de uno en que un tercero "imparcial" tiene la necesidad de acercarse a la verdad objetiva de los hechos. Por lo mismo, deberíamos asumir que existe un riesgo mucho mayor que la preparación de testigos pueda exceder el ámbito de lo tolerable. Los jueces, por ello, deberían ser especialmente receptivos a la información que pueda surgir -sobre la base del contrainterrogatorio, pero también por sus propias preguntas- ${ }^{144}$ sobre cómo se desarrolló el proceso de preparación y cuál fue exactamente el ámbito que aquel abarcó.

Asimismo, debería considerarse que, conforme lo ha reconocido la doctrina comparada, existen ciertos testigos que son especialmente sensibles a técnicas de entrenamientos sugestivas e inapropiadas, en particular, los niños, los testigos que han participado en procesos de identificación y los testigos que tienen un especial interés de colaborar o cooperar con la fiscalía. ${ }^{145}$

La literatura comparada ha identificado algunas prácticas que no se deben realizar en la preparación de los testigos y peritos:

1. Ayudar a que los testigos y peritos conozcan otras declaraciones o antecedentes de la investigación, en especial, cuestiones relacionas con:

a. Identificación o reconocimientos de los imputados.

b. Prueba material incriminatoria que el testigo o perito desconozca.

c. Las declaraciones (en lo concordante como en lo contradictorio) de otros testigos o peritos.

\footnotetext{
${ }^{142}$ Porque, como lo explican Walker y McCartney, el sistema adversarial genera fuertes incentivos que animan a los fiscales y defensores a ser selectivos en sus versiones de la realidad. Véase, WALKER, Clive; MCCARTNEY, Carole, "Criminal justice and miscarriages of justice in England and Wales", en: HUFF/KILLIAS, Wrongful Conviction, cit. nota $n^{\circ} 10$, p. 183. La pregunta es, cómo un juez, sabiendo eso, puede tener la tranquilidad que desde su asiento pasivamente va descubrir la verdad, como algo que está ahí, en el aire, lista para ser recogida.

${ }^{143}$ Véase, GERSHMAN, "Witness Coaching”, cit. nota n 141, p. 833.

${ }^{144}$ Artículo 329 del CPP.

${ }^{145}$ Véase, GERSHMAN, “Witness Coaching” cit. nota n 141, pp. 844 y ss.
} 
Polit. crim. Vol. 8, No 15 (Julio 2013), Art. 7, pp. 249 - 313.

[http://www.politicacriminal.cl/Vol_08/n_15/Vol8N15A6.pdf]

2. Explicarle al testigo (o al imputado) las cuestiones específicas de derecho y como ciertos hechos se subsumirían mejor o peor en un determinado tipo penal o en una eximente. ${ }^{146}$

Y más específicamente se debería evitar, al preparar a una víctima, testigo o perito:

1. Eliminar inconsistencias entre el testimonio que un testigo o perito prestó al inicio de la investigación y lo que se espera sea su testimonio definitivo en el juicio.

2. Aconsejarle explícitamente al testigo o perito que evite detalles que puedan perjudicar su credibilidad y dañar su testimonio. En este sentido, es muy común que las partes le digan a la víctima, testigo o perito que en vez de decir que "tiene dudas", "que la verdad es que no sabría como recordarlo bien", "que tiene una imagen borrosa de ciertas cosas", mejor expresen que "no se acuerda" o "que no sabe". Como cualquiera comprenderá, para el Tribunal la correspondencia con la verdad de una afirmación como "tengo dudas de como exactamente sucedió eso" versus "no lo recuerdo" o "no lo sé" es radicalmente distinta.

3. Manejar la información -lo que se conoce como bloquear la información- que pueda revelar que el fiscal ha suprimido o evitado presentar un determinado testimonio y evidencia. ${ }^{147}$

Todos estos son elementos que los tribunales deberían considerar para valorar la calidad epistémica de la información, en términos que la misma surja en un proceso libre de contaminación que pueda afectar la correspondencia entre la preposición fáctica de la acusación y los hechos.

Por otra parte, y como sugiere Flowers, se debería excluir la práctica de preparar conjuntamente a los testigos de un caso. Esta preparación en grupo, que se hace para ahorrar tiempo, darle coherencia a los relatos, permitir a los testigos tener un mayor cuadro de los hechos y evitar que se contradigan, es fuertemente cuestionada porque con ello el abogado (de manera directa o indirecta) le transmite a los testigos que sus testimonios deben ser consistentes. Es, por lo mismo, una fuerte invitación a los testigos a adecuar sus testimonios en los términos que sean coherentes entre sí, que no presenten inconsistencia ni lagunas de información. Ello se agrava si durante esa preparación en grupo el abogado destaca los puntos problemáticos de las distintas declaraciones, intentando con ello que el testigo comprenda las dificultades de su testimonio. ${ }^{148}$

Este escenario se ve aún más agravado porque las partes tienen la habilidad-consciente o inconscientemente- de fortalecer su caso preguntándole y sugiriéndole cosas al testigo para llenar sus vacíos de la memoria, dar énfasis y alterar prejuicios. Pero además, porque algunos testigos (en especial las víctimas que confían en los fiscales) son especialmente vulnerables a las sugerencias de los fiscales, receptivos a sus dudas y temores respecto de la causa.

\footnotetext{
${ }^{146}$ Véase, FRANKEL, Partisan Justice, cit. nota n ${ }^{\circ}$ 6, p. 15.

${ }^{147}$ Véase, GERSHMAN, "Witness Coaching” cit. nota n ${ }^{\circ} 141$ p. 833 y s.

${ }^{148}$ Véase FLOWERS, “Witness Preparation”, cit. nota ${ }^{\circ} 141$, pp. 1019 y ss.
} 
CASTILLO, Ignacio. "Enjuiciando al proceso penal chileno desde el inocentrismo (algunos apuntes sobre la necesidad de tomarse en serio a los inocentes)."

Desafortunadamente en Chile aún no existe una preocupación seria sobre este tema, no se ha generado ninguna herramienta profiláctica que impida -0 por lo menos desincentive- estas prácticas. Por el contrario, no son pocas las veces que una parte generalmente la fiscalía- se opone cuando la otra pretende indagar sobre estas circunstancias, porque supuestamente esas preguntas serían impertinentes, engañadoras o coactivas -todo lo cual no es cierto-, y en no pocos casos los jueces lamentablemente acogen esas objeciones. Esto es algo que debe cambiar.

Por otra parte, la experiencia comparada indica algunas medidas que se podrían tomar para reducir los casos de entrenamiento inadecuados de testigos y peritos, como serían:

1. Grabar o registrar estos procesos de preparación para poder ser revisados por la contraparte, de considerarse necesario.

2. Establecer la posibilidad de una audiencia preliminar (antes del juicio) para que las partes, en caso de existir algún indicio, puedan explorar la posibilidad de la contaminación de un testigo (especialmente relevante con los testigos que han participado en procesos de identificaciones)

3. Generar procesos de capacitación y entrenamiento sobre técnicas de preparación de testigos y peritos para el juicio oral, a fin de incentivar buenas prácticas capaces de reducir las situaciones de inadecuado entrenamiento.

Por último, me parece esencial que los actores del sistema, y las propias instituciones, vayan fijando estándares que supongan un sistema de control y autolimitación respecto de la existencia de inadecuadas técnicas de preparación, pero también que permitan detectar la posibilidad de presentar testigos que eventualmente pudieran cometer perjurio. Así, por ejemplo, la Fiscalía Nacional debería desarrollar un instructivo o un manual de adecuadas prácticas de preparación de testigo y peritos $\mathrm{y}$, además, se podría establecer -aunque sea para los casos complejos- un sistema de compliance officer, o sea, un funcionario de la misma fiscalía, con suficiente jerarquía institucional, que pueda controlar y oponerse a malas prácticas, y que tenga la responsabilidad de vigilar que los fiscales y asistente de fiscales respeten las normas legales y éticas a la hora de entrevistar y preparar los testigos y peritos.

Sumado a lo anterior, pero en el plano individual, no es suficiente confiar que el control horizontal del sistema va ser suficiente para revelar el perjurio de un testigo o perito. Es también responsabilidad de cada interviniente evitar presentar testigos que puedan cometer perjurio y, por lo mismo, lo relevante es fijar estándares a partir de los cuales se pueda ponderar esto y tomar la decisión respectiva. Así, por ejemplo, la experiencia norteamericana fija dos estándares, por un lado, que el abogado debe saber más allá de toda duda razonable que el testigo va cometer perjurio antes de rehusarse a llamar al testigo al juicio oral; ${ }^{149}$ el segundo, que el abogado debe tener un conocimiento actual $o$ al menos una base fáctica firme- que el testimonio va a resultar en un perjurio. ${ }^{150}$ Como dice Altman, la víctima, el testigo y el perito comparten con el abogado (incluido el fiscal) la responsabilidad de asegurar la veracidad en el testimonio. El declarante nunca debería testificar sobre algo que él o ella no cree verdadero. Un abogado nunca

\footnotetext{
${ }^{149}$ Shockley v. State, 565 A.2d 1373, 1379.

${ }^{150}$ Whiteside v. Scurr, 744 F.2d 1323, 1328 (8th Cir. 1984), rev 'd on other grounds sub nom. Nix v. Whiteside, 475 U.S. 157 (1986).
} 
Polit. crim. Vol. 8, No 15 (Julio 2013), Art. 7, pp. 249 - 313.

[http://www.politicacriminal.cl/Vol_08/n_15/Vol8N15A6.pdf]

debería permitir o ayudar a un testigo, a una víctima o a un perito a declarar algo que el abogado crea, basado en su conocimiento personal o en una base fáctica firme, que es falso. $^{151}$

En definitiva, las declaraciones previas y la preparación de los testigos, víctimas y peritos para el juicio oral es otro factor en que confluyen dos miradas -no del todo excluyentes- del proceso penal. Una que tiende a valorar todo desde la protección de los derechos fundamentales reduciendo todas las discusiones a cuestiones de protección de garantías y al debido proceso y otra que, en cambio, tiene una fuerte preocupación por los problemas epistémicos del proceso penal que a veces impiden o dificultan el acercamiento a la verdad. En estos puntos específicos es evidente que en ciertos casos la preparación del testigo podrá ser a tal nivel inadecuada que efectivamente suponga la vulneración de ciertos derechos fundamentales (v. gr. el debido proceso, el derecho a la defensa, la posibilidad de poder confrontar -legítimamente- la prueba de cargo, etc.) pero en otros, en cambio, el problema no será uno de garantías, sino que cognoscitivo, es decir, de determinar hasta qué punto esa prueba que se presenta pueda ser considerada suficientemente creíble para validar la proposición que se supone pretende afirmar. Lograr esto último supone un fuerte control de la información, control que debe interesar sobre todo a los jueces adjudicadores que son los llamados a determinar la verdad en el proceso penal. Por eso, creo que los jueces lejos de inhibir los reclamos frente a supuestas preparaciones inadecuadas de los testigos, deberían ser los primeros abiertos a escuchar -incluso con medidas que los obliguen a salirse de su pasividad- ${ }^{152}$ a fin de poder luego tomar la decisión con la mejor información posible.

\section{Conclusiones}

La intención del presente artículo no era terminar una discusión que, sin duda, puede generar un debate largo e infinitamente necesario para nuestro sistema procesal penal. El propósito era mucho más modesto, tan sólo dar los primeros lineamientos de un problema del proceso penal que hasta ahora creo ha sido insuficientemente tratado por nuestra doctrina y jurisprudencia, a saber, el de los fácticamente inocentes que terminan condenados.

Es cierto que en Chile no existen datos estadísticos sobre este problema y a penas tenemos un puñado de casos en que se podría decir que se condenó a un inocente. Ello, sin embargo, no es óbice para que, a partir de la enorme literatura comparada, podamos advertir que la manera en que funciona el proceso penal chileno, la escasa regulación, la exigua y a veces contradictoria jurisprudencia que existe sobre algunos aspectos sensibles del proceso, permitan predecir que el fenómeno de los inocentes condenados es bastante mayor del que creemos.

\footnotetext{
${ }^{151}$ ALTMAN, "Witness Preparation Conflicts", cit. nota n 130, p. 39.

${ }^{152}$ De nuevo me refiero a la utilización de la herramienta del artículo 329 del CPP, que tiene una doble cara. Por un lado puede ser una adecuada herramienta para que un juez pueda participar, desde una perspectiva orientada a la búsqueda de la verdad, del debate y mejorar la calidad de la información que surge del juicio pero, también, como una herramienta para que el juez se deje llevar por sus prejuicios cognitivos, por sus suposiciones y únicamente intente comprobar las hipótesis que van surgiendo en su proceso de convicción. Un juez debe acercarse a lo primero y alejarse de lo último.
} 
CASTILLO, Ignacio. "Enjuiciando al proceso penal chileno desde el inocentrismo (algunos apuntes sobre la necesidad de tomarse en serio a los inocentes)."

En definitiva, mi tesis es que el sistema que se implementó con el nuevo proceso penal, en especial en el juicio oral, es excesivamente adversarial, con una pretensión de igualdad de parte que, además de ingenua, genera enormes costos para los imputados inocentes y con un proceso en que las partes lejos de buscar la verdad, están enfocados en cumplir un determinado rol (fiscales y defensores), en terminar rápido las causas en que hay "acuerdo" y, en las que no, ganarle al rival; todo eso en un contexto de jueces de garantía y de tribunal oral que en lo sustantivo son extremadamente pasivos para no perder la así llamada "imparcialidad judicial" (en una concepción demasiado extensiva de la misma). ${ }^{153}$

Sostengo que el sistema de justicia criminal debería tener como principal objetivo proteger al imputado " $f$ inocente", a quien no ha cometido el delito, y el sistema adversarial -más aún el que se ha implementado en Chile- simplemente no está diseñado para eso. Por el contrario, las principales barreras de protección (profilácticas) están explícitamente diseñadas como obligaciones de respetar garantías individuales, ello a fin de evitar intromisiones abusivas por parte del Estado en la persecución penal, la facilitación - a costa del individuo- de la investigación estatal y la protección de la dignidad y autonomía: todo ello aplicable al conjunto universal de imputados, pero sin una preocupación especial por los "f inocentes". Son muy pocas las normas del CPP, como es fácil de observar, que buscan específicamente mejorar la calidad epistémica de la información sobre la cual se toma la decisión adjudicativa. ${ }^{154}$

Tomarse en serio al inocente supone, además de ser estrictos con los principios cardinales del proceso penal (v.gr. presunción de inocencia, carga de la prueba en el

${ }^{153}$ En aquellas causas en que existe contradictoriedad se ha ido instalando lo que anunciaban Duce y Baytelman, en su manual de litigación, a saber, que el modelo "acusatorio contenido en el nuevo Código Procesal Penal está diseñado sobre la base de una importante confianza en la competencia adversarial; esto es, en la idea de que el proceso -y especialmente el juicio- promueve el enfrentamiento intenso entre las partes y apuesta a que esta instancia de confrontación arrojará la mayor cantidad de información sobre el caso, a la vez que depurará la calidad de dicha información." BAYTELMAN, Andrés; DUCE, Mauricio, Litigación penal. Juicio oral y prueba, Santiago: Universidad Diego Portales, 2004, p. 21. El objetivo del presente trabajo es justificar por qué, considerando el sistema actual chileno, esta aproximación es riesgosa para el objetivo de evitar condenar a " $f$ inocentes". El problema de esa mirada, como bien lo afirma McEwan es que pone un acento excesivo sobre las partes, más que en la justicia. Es cierto, dice el autor, que "los abogados no deben considerarse jueces, pero no parece haber buenas razones para que, si el tribunal considera [en casos excepcionales] que una particular evidencia debería producirse para esclarecer el conocimiento del tribunal, las partes puedan impedírselo. A menos, claro está, que los procedimientos en los tribunales sean vistos sólo como instrumentos de las partes para usarlos a su antojo, más que cómo una institución importante en la sociedad y un elemento esencial en la aplicación y desarrollo del derecho". MCEWAN, Jenny, Evidence and the Adversarial Process, The Modern Law, Oxford, Cambridge: Blackwell Business, 1992, p. 7.

${ }^{154}$ Comparten esta aproximación en el sistema norteamericano Zacharias y Green, para quienes el modelo adversarial americano busca prevenir condenas erróneas principalmente sobre la base de un proceso diseñado para asegurar que el riesgo del error recaiga en el lado de la absolución, más que de la condena. Sin embargo, se muestran evidentemente preocupados de la posibilidad que malas prácticas de la persecución puedan afectar, o incluso alterar, este principio. Sobre esto véase, ZACHARIAS, Fred; GREEN, Bruce, "The Duty to Avoid Wrongful Convictions: A Thought Experiment in the Regulation of Prosecutors", Boston University Law Review, v. 89 (2009). Por otra parte, Damaška reconoce que las mayores barreras a las condenas que genera el modelo adversarial reflejan "un sacrificio consciente de la certeza en la determinación de los hechos, por el bien de otros valores". Véase DAMAŠKA, Mirjan, "Evidentiary Barriers to Conviction and two Models of Criminal Procedure: A Comparative Study", University of Pennsylvania Law Review Vol. N 121 (1973), pp. 506-589, p. 525. 
Polit. crim. Vol. 8, No 15 (Julio 2013), Art. 7, pp. 249 - 313.

[http://www.politicacriminal.cl/Vol_08/n_15/Vol8N15A6.pdf]

Ministerio Público, in dubio pro reo, y estándar de convicción más allá de toda duda razonable), preocuparse de la forma en que investigan las policías, exigirles un carácter más neutral, que sean capaces no sólo de recoger prueba incriminatoria sino que también exculpatoria (aunque contradiga su teoría del caso); que generen protocolos, capacitaciones y desarrollen las mejores prácticas para evitar la visión de túnel; regular y transparentar la relación entre las policías y el Ministerio Público; exigirle al órgano persecutor que defina protocolos y prácticas para que las policías les entreguen toda la información inculpatoria pero, por sobre todo, la exculpatoria; determinar el preciso sentido del principio de objetividad y buscar mecanismos para regularlo y fortalecerlo; determinar la manera en que se deben realizar los peritajes y la relación de los peritos como entes neutrales y no como partes interesadas, en especial de la persecución; regular las formas y los medios de registro en que se deben realizar los reconocimientos y las declaraciones ante la fiscalía; regular la forma en que el imputado debe positivamente renunciar a su derecho a guardar silencio y confesar, además en la forma en que ello se debe registrar; ampliar las facultades y obligaciones de los jueces de garantía para que además de su rol cautelar, cumplan cierto control material sobre la investigación; además, a estas alturas del proceso nos debería preocupar y deberíamos reglamentar la preparación de los testigos -ya sea por la fiscalía como por la defensa- y definir qué cosas se pueden hacer o decir, incluso no sería inadecuado que la fiscalía comenzara a grabar las preparaciones de los juicios; pero, por sobre todo, reforzar la idea del rol de los jueces orales (o de garantía, en su función adjudicativa) como verdaderos responsables de determinar la verdad y abandonar esa posición estricta de la imparcialidad, como si ella fuera lo único relevante en el proceso penal.

En conclusión, y parafraseando a Damaška, el objetivo central del presente trabajo es recordar lo importante que es desarrollar incentivos adecuados para contrarrestar, o minimizar, las tentaciones de las partes de caer en conductas distorsionadoras de la verdad. ${ }^{155} \mathrm{Y}$, en eso no creo que exista una doble lectura, el modelo chileno está al debe. Y es que, como lo señaló el presidente de la Corte Suprema de Canadá, en un reporte sobre tres condenas erróneas, la

"responsabilidad para prevenir condenas erróneas, recae en todos los participantes del sistema de justicia criminal. Policías, fiscales, peritos, jueces y defensores, todos tienen un rol que jugar para asegurar que personas inocentes no sean condenadas de crímenes que no cometieron". ${ }^{156}$

Su llamado es evidente, alcanzar consensos para diseñar normas institucionales y culturales que alienten las responsabilidades colectivas e individuales para prevenir injusticias. Ese llamado, al menos hasta ahora, en Chile nadie lo ha hecho.

El sistema chileno ha generado, en cambio, un proceso que cuando las partes no logran un acuerdo rápido, incentiva la batalla y alienta a las partes a encerrarse en su versión de los hechos y suprimir versiones conflictivas con su propia teoría del caso. Por lo

${ }^{155}$ Véase, DAMAŠKA, Mirjan, "Epistemology and legal regulation of proof", Law, Probability and Risk Vol. $\mathrm{N}^{\circ} 2$ (2003), p. 120.

${ }^{156}$ Véase, SOROCHAN, Donald, "Wrongful Convictions: preventing miscarriages of justice, some case studies", Texas Tech Law Review Vol. № 41 (2008), pp. 93-116, p. 101 (citando a LAMER, Antonio, The Lamer Commission of Inquiry Pertaining to the cases of: ronald dalton, gregory parsons, randy druken (2006). 
CASTILLO, Ignacio. "Enjuiciando al proceso penal chileno desde el inocentrismo (algunos apuntes sobre la necesidad de tomarse en serio a los inocentes)."

mismo, es un sistema que premia al obtuso, al enceguecido en su teoría y al que -sin detenerse a reflexionar sobre la posibilidad del error- sigue adelante con la única intención de ganar. En cambio, censura a quien abierto a considerar la posibilidad que la tesis de la contraparte sea la correcta, realice esfuerzos por apartarse de su propia teoría del caso asumiendo con objetividad la posición de la contraria. Con ese mirada, parafraseando al profesor Thomas, no sería extraño que -aunque no existan investigaciones empíricas en nuestro país- al igual que en Estados Unidos, la mayor causa de condenas erróneas se deba precisamente al sistema adversarial. ${ }^{157}$

El problema central es, siguiendo con Thomas, que en Chile a partir de la reforma no tenemos ninguna institución cuyo fin principal (ni menos específico) sea la búsqueda de la verdad. ${ }^{158}$ Esperemos que esa situación no esté hoy perjudicando a los inocentes. La invitación por último, es a continuar con este debate, a tomarnos en serio a los inocentes, a investigar la capacidad actual del sistema de evitar condenar inocentes y, de ser necesario, proponer los cambios que sean necesarios, sin miedo a criticar ciertos dogmas que, lamentablemente, se han ido acentuando en nuestro país con escasa autocrítica.

\footnotetext{
${ }^{157}$ Véase, THOMAS, George, The Supreme Court on Trial: How the American Justice System Sacrifices Innocent Defendants, University of Michigan Press, 2008, pp. 12 y ss.

${ }^{158}$ THOMAS, The Supreme Court on Trial, cit. nota $\mathrm{n}^{\circ} 157$, pp. 12 y ss.
} 
Polit. crim. Vol. 8, No 15 (Julio 2013), Art. 7, pp. 249 - 313.

[http://www.politicacriminal.cl/Vol_08/n_15/Vol8N15A6.pdf]

\section{BIBLIOGRAFÍA}

AA.VV., 10 años de la Reforma Procesal Penal: Los desafíos del nuevo sistema, Santiago: Ministerio de Justicia, 2010.

ACCATINO SCAGLIOTTI, Daniela, "La fundamentación de la declaración de hechos probados en el nuevo proceso pena. Un diagnóstico", Revista de Derecho de la Universidad Austral de Chile Vol. XIX, № 2 (2006).

, "El modelo legal de justificación de los enunciados probatorios en las sentencias penales y su control a través del recurso de nulidad", en ACCATINO SCAGLIOTTI, Daniela (Coord.): Formación y valoración de la prueba en el proceso penal, Santiago: Ed. Abeledo Perrot, 2010.

" "Certezas, dudas y propuestas en torno al estándar de la prueba penal", Revista de Derecho de la Pontificia Universidad Católica de Valparaíso Vol. $\mathrm{N}^{\circ}$ XXXVII (2do Semestre 2011).

AGRICOLA, Barbara, "The Psychology of Pretrial Identification Procedures: The Showup is Showing out and Undermining the Criminal Justice System", Law \& Psychology Review Vol. No 33 (2009).

ALLEN, Ronald; LAUDAN, Larry, "Deadly Dilemmas", Texas Tech Law Review Vol. $\mathrm{N}^{\circ} 41$ (2008-2009), pp. 65-92.

ALTMAN, James, "Witness Preparation Conflicts", Litigation Vol. № 22 (1995), pp. 38-68.

APPLEGATE, John, "Witness Preparation”, Texas Law Review Vol. №68 (1989), pp. 277-352.

BÁEZ, Danilo, “¿Estándar de convicción o arbitrariedad judicial? Bases y propuestas para la interpretación del estándar de "duda razonable" en el Código Procesal Penal”, en: VERDUGO, Mario (Dir.), Gaceta Jurídica, Doctrinas Esenciales, Derecho Penal. T.1, Santiago: Legal Publishing Chile, 2011.

BAYTELMAN, Andrés; DUCE, Mauricio, Litigación penal Juicio oral y prueba, Santiago: Universidad Diego Portales, 2004.

BERNSTEIN, David, "Junk Science in the United States and the Commonwealth", Yale Journal of International Law, Vol. № 21 (1996), pp. 123-182.

BROOKS, Peter, Troubling Confessions: Speaking Guilt in Law and Literature, Chicago: University of Chicago Press, 2000.

CAMPBELL, Kathryn, "The fallibility of justice in Canada, a critical examination of conviction review", en: HUFF, Ronald; KILLIAS, Martin (Eds.), Wrongful Conviction, International Perspectives on Miscarriages of Justice, Filadelfia: Temple University Press, 2008.

CASSELL, Paul, "Miranda's Social Costs: An Empirical Reassessment", Northwestern University Law Review, Vol. ํo 90 (1996), pp. 387-498.

COLOMA CORREA, Rodrigo, "Panorama General de la Prueba en el Juicio Oral", en: COLOMA CORREA, Rodrigo, (Ed.), La Prueba en el Nuevo Proceso Penal Oral, Santiago: Ed. LexisNexis, 2003.

COLOMA, Rodrigo; PINO, Mauricio; MONTECINOS, Carmen, "Fundamentación de Sentencias Judiciales y Atribución de Calidad Epistémica a las Declaraciones de Testigos en Materia Procesal Penal", Revista de Derecho de la Pontifica Universidad Católica de Valparaíso, Vol. XXXIII (2009), pp. 303-344.

DAMAŠKA, Mirjan, "Evidentiary Barriers to Conviction and Two Models of Criminal Procedure: A Comparative Study", University of Pennsylvania Law Review, Vol. $\mathrm{N}^{\circ} 121$ (1973). 
CASTILLO, Ignacio. "Enjuiciando al proceso penal chileno desde el inocentrismo (algunos apuntes sobre la necesidad de tomarse en serio a los inocentes)."

, "Presentation of Evidence and Factfinding Precision", University of Pennsylvania Law Review Vol. № 123 (1975), pp. 1083 - 1106. , Evidence Law Adrift, New Haven, London: Yale University Press, 1997. , "Epistemology and legal regulation of proof", Law, Probability and Risk Vol. No 2 (2003).

DEL RIO, Carlos, "Dos formas discutibles de poner en duda el carácter cognoscitivo de la aplicación judicial del Derecho penal: el principio de consenso y la garantía de la no agravación punitiva", Revista de Derecho de la Pontificia Universidad Católica de Valparaíso, Vol. N XXXIV (2010), pp. 349-383.

DRESSLER, Joshua; MICHAELS, Alan, Understanding Criminal Procedure, Vol. 2, Adjudication, 4ta Ed. Estados Unidos: West Group, 1999.

DUCE, Mauricio; RIEGO, Cristián, Proceso Penal, Santiago: Editorial Jurídica de Chile, 2007.

EDMOND, Gary; SAN ROQUE, Mehera, "The Cool Crucible: Forensic Science and the Frailty of the Criminal Trial", Current Issues in Criminal Justice, Vol. N ${ }^{\circ} 24$ (2012), pp. 51-68.

FERNANDEZ, José Manuel; OLAVARRÍA, Malva, "Teoría y Práctica de la Acción de Revisión en el Nuevo Código Procesal Penal, Causal Letra d) del Artículo 473", Ius et Praxis Vol. № 2, Año 15 (2009), pp. 215-255.

FINDLEY, Keith; SCOTT, Michael, "The Multiple Dimensions of Tunnel Vision in Criminal Cases", Wisconsin Law Review, Vol. N² 2006, pp. 291-397.

FISHER, Stanley, "Just the Facts, Ma'am": Lying and the Omission of Exculpatory Evidence in Police Reports", New England Law Review Vol. N² 8 (1993), pp. 162.

FLOWERS, Roberta, "What You See Is What You Get. Applying the Appearance of Impropriety Standard to Prosecutors", Missouri Law Review Vol. N 63 (1998), pp. 699-766.

,"Witness Preparation: Regulating the Profession's 'Dirty Little Secret", Hastings Constitutional Law Quarterly Vol. N 38 (2011), pp. 1007-1028.

FRANKEL, Marvin, Partisan Justice. Too much fight? Too little truth? Equal Justice? New York: Hill and Wang, 1978.

GARCIA, Ramón, "El Ejercicio del Derecho a Defensa Técnica en la Etapa Preliminar del Proceso Penal", en: FUENTES, Claudio (Coord.), Diez años de la reforma procesal penal en Chile, Santiago: Ediciones Universidad Diego Portales, 2011.

GARRETT, Brandon, Convicting the innocent: Where Criminal Prosecutions go Wrong, Boston: Harvard Univ. Press, 2011.

"Innocence, Harmless Error, And Federal Wrongful Conviction Law", Wisconsin Law Review, Vol. No 35 (2005), pp. 35-114.

GERSHMAN, Bennett, "Child Witnesses and Procedural Fairness", American Journal of Trial Advocacy Vol. $\mathrm{N}^{\circ} 24$ (2001), pp. 568-608.

, "Witness Coaching By Prosecutors", Cardozo Law Review Vol. № 23 (2002), pp. 829-863.

GIANNELLI, Paul, "The Abuse of Scientific Evidence in Criminal Cases: The Need for Independent Crime Laboratories", Virginia Journal of Social \& the Law Vol. N 4 (1997), pp. 439-478.

, "Forensic Science and the ABA Innocence Report", Southwestern University Law Review Vol. N 37 (2008), pp. 993-1007. 
Polit. crim. Vol. 8, No 15 (Julio 2013), Art. 7, pp. 249 - 313.

[http://www.politicacriminal.cl/Vol_08/n_15/Vol8N15A6.pdf]

"Independent Crime Laboratories: The Problem of Motivational and Cognitive Bias", Utah Law Review Vol. N² (2010), pp. 247-266.

GOULD, Laurie; VON HATTEN, Brian; STICKELS, John, "Reforming the use of Eyewitness Testimony", Oklahoma City University Law Review, Vol. N ${ }^{\circ} 35$ (2010), pp. 131-146.

GUERRA, Sandra, "Eyewitness Identifications and State Courts as Guardians Against Wrongful Conviction”, Ohio State Journal of Criminal Law Vol. N7 (2010), pp. 603-635.

HAACK, Susan, "Inquiry and advocacy, fallibilism and finality: culture and inference in science law", Miami Law Research Paper Series Vol. N 2 (2003), pp. 205214.

, "Epistemology Legalized: or, truth, justice, and the american way", descargable en http://www.as.miami.edu/phi/haack/EPISTLEG.pdf .

HARTMAN, Rhiannon, "Why the Innocence Movement should focus on proscriptive pre-conviction measures instead of abolition of the Death Penalty", Richmond Journal of Law and the Public Interest Vol. 12, N 2 (2009), pp. 163-187.

INBAU, Fred; REID, John, et. al., Criminal Interrogation And Confessions, Burlington: Jones \& Bartlett Learning, $5^{\circ} \mathrm{Ed}, 2011$.

JACKSON, John, "Theories of Truth Finding in Criminal Procedure: An Evolutionary Approach", Cardozo Law Review Vol. № 10 (1988-1989).

JOHNSON, Gail, "False Confessions and Fundamental Fairness: The Need for Electronic Recording of Custodial Interrogations", Public Interest Law Journal Vol. 6 (1997), pp. 719-751.

KAGAN, Robert, La giustizia americana: come il contradditorio fa il diritto, Ed. Italiana: TARUFFO, Michele, (Dir.), Bologna: Il Mulino, 2009.

KAMISAR, Yale, "On the 'Fruits' of Miranda Violations, Coerced Confessions and Compelled Testimony”, Michigan Law Review Vol. № 93 (1995), pp. 929-1010.

KAUFMAN, Fred, Commission on Proceedings Involving Guy Paul Morin, 1998, pp. 1235-1239.

KILLIAS, Martin, "Wrongful Convictions in Switzerland", en: HUFF, Ronald; KILliAS, Martin (Eds.), Wrongful Conviction, International Perspectives on Miscarriages of Justice, Filadelfia: Temple University Press, 2008.

LARUSSO, Sergio, "La prova scientifica", en: GAITO, Alfredo (Dir.), La Prova Penale, Torino, Utet Giuridica, 2008.

LEE, Jessica, "No Exigency, no Consent: Protecting Innocent Suspects from the Consequences of Non-Exigent Show-Ups", Columbia Human Rights Law Review Vol. No 36 (2005), pp. 755-599.

LEO, Richard, "Inside the Interrogation Room", Journal of Criminal Law and Criminology Vol. No 86 (1996), pp. 266-393. , "Police Interrogation and Social Control", Social and Legal Studies Vol. $\mathrm{N}^{\circ} \quad 3$ (1994). descargable en http://papers.ssrn.com/sol3/papers.cfm?abstract id=1141372.

LEO, Richard, et al., "Bringing Reliability Back In: False Confessions and Legal Safeguards in the Twenty-First Century", Wisconsin Law Review Vol. N ${ }^{\circ} 2006$, pp. 479-539.

LEO, Richard; KASSIN, Saul, et al., "Police-Induced Confessions: Risk Factors and Recommendations", Law and Human Behavior Vol. No 34 (2010), pp. 93-120. [texto descargable

en http://papers.ssrn.com/sol3/papers.cfm?abstract id=1483878]. 
CASTILLO, Ignacio. "Enjuiciando al proceso penal chileno desde el inocentrismo (algunos apuntes sobre la necesidad de tomarse en serio a los inocentes)."

LESAGE, Patrick, Report of the Commission of Inquiry into Certain Aspects of the Trial and Conviction of James Driskell, 2007.

LINDSAY, R.C.; POZZULO, Joanna; GRAIG, Wendy, et al., "Simultaneous Lineups, Sequential Lineups, and Showups: Eyewitness Identification Decisions of Adults and Children", Law and Human Behavior Vol. 21 (1997), pp. 391-404.

MARTIN, Dianne, "Lessons about Justice from the 'Laboratory' of Wrongful Convictions: Tunnel Vision, the Construction of Guilt and Informer Evidence", UMKC Law Review Vol. No 70 (2002), pp. 847-864.

McEWAN, Jenny, Evidence and the Adversarial Process, The Modern Law, Oxford, Cambridge: Blackwell Business, 1992.

MEDWED, Daniel, "Innocentrism”, University of Illinois Law Review Vol. № 2008, pp. $1549-1572$.

MORALES, Ana María; WELSCH, Gherman, El reconocimiento de imputados en Chile y a nivel comparado, Santiago: Fundación Paz Ciudadana, julio 2011.

PALEY, William, The Principles of Moral and Political Philosophy, Indianapolis: Liberty Fund, 2002.

Revista 93, 10 años de la Reforma Procesal Penal, Revista de la Defensoría Penal Pública Vol. N 4, (2010).

Revista 93, Inocentes, Revista de la Defensoría Penal Pública Vol. º 6 (2011).

RING, Sinead, "Due Process and the admission of expert evidence on recovered memory in historic child sexual abuse cases: lessons from America", The International Journal of Evidence \& Proof Vol. $\mathrm{N}^{\circ} 16$ (2012), pp. 66-92.

RISINGER, Michael; RISINGER, Lesley, "Innocence is Different: Taking Innocence into Account in Reforming Criminal Procedure", descargable en http://ssrn.com/abstract=1783941.

SALAS, Jaime, Problemas del Proceso Penal, investigación, etapa intermedia y procedimientos especiales, Santiago: Librotecnia, 2009.

SALTZBURG, Stephen, "Lawyers, Clients, and the Adversary System", Mercer Law Review Vol. № 37 (1985-1986), pp. 647-700.

SANTELICES, Fernando, "Contradicción, Imparcialidad e Inmediación en la Ley de Enjuiciamiento Civil Española. Algunos problemas para la consolidación de estos principios en la práctica", Ius et Praxis Año 18, N 1 (2012).

SCHERR, Kyle; MADON, Stephanie, "You Have the Right to Understand: The Deleterious Effect of Stress on Suspects' Ability to Comprehend Miranda", Law and Human Behavior Vol. N 36 (Aug. 2012), pp. 275-282.

SIMON, Dan, "The Limited Diagnosticity of Criminal Trials", Vanderbilt Law Review Vol. N 64 (2011), pp. 143-223.

SOROCHAN, Donald, "Wrongful Convictions: preventing miscarriages of justice: some case studies", Texas Tech Law Review Vol. N 41, (2008), pp. 93-116.

STEBLAY, Nancy, "Maintaining the Reliability of Eyewitness Evidence: After the Lineup", Creighton Law Review Vol. N 42 (2009), pp. 643-654.

STELLA, Federico, Giustizia e Modernità, La protezione dell'innocente e la tutela delle vittime, Milano: Giuffrè Editore, 3a Edicion, 2003.

STRIER, Franklin, "Major Problems Endemic to the Adversary System and Proposed Reform", Western State University Law Review Vol. № 19, (1991-1992), pp. 463392. 
Polit. crim. Vol. 8, No 15 (Julio 2013), Art. 7, pp. 249 - 313.

[http://www.politicacriminal.cl/Vol_08/n_15/Vol8N15A6.pdf]

SULLIVAN, Thomas, "Electronic Recording of Custodial Interrogations: everybody wins", The Journal of Criminal Law and Criminology Vol. $\mathrm{N}^{\circ} 95$ (2005), pp. 1127-1144.

, "Police experiences with recording custodial interrogations", Judicature, Vol. No 88 (2004), pp. 132-136.

TARUFFO, Michele, La semplice verità. Il giudice e la costruzione dei fatti, Roma Bari: Editorial Laterza, 2009.

THOMAS, George, The Supreme Court on Trial: How the American Justice System Sacrifices Innocent Defendants, University of Michigan Press, 2008.

VIAL, Pelayo, "El derecho a confrontación con declaraciones de un juico anulado en el marco del proceso penal", Política Criminal Vol. 6, N 12 (2011), pp. 448-473.

VOLOKH, Alexander, “N Guilty Men”, University Of Pennsylvania Law Review Vol. $\mathrm{N}^{\circ}$ 146, (1997-1998), pp. 173-216.

WALKER, Clive; MCCARTNEY, Carole, "Criminal Justice And Miscarriages Of Justice In England And Wales", en: HUFF, Ronald; KILLIAS, Martin (Eds.), Wrongful Conviction, International Perspectives on Miscarriages of Justice, Filadelfia: Temple University Press, 2008.

WELLS, Gary; FERGUSON, Tamara; LINDSAY, R.C., "The tractability of eyewitness confidence and its implications for triers of fact", Journal of Applied Psychology Vol. N 66 (1981), pp. 688-696.

WELLS, Gary; SMALL, Mark; PENROD, Steven, et al., "Eyewitness identification procedures: Recommendations for lineups and photospreads", Law and Human Behavior Vol. 22, nº 6 (1998), pp. 603-647.

WIGMORE, John Henry, Evidence in trials at Common Law, Boston, Toronto: Little Brown (1970).

WHITE, Welsh, "False Confessions and the Constitution: Safeguards Against Untrustworthy Confessions", Harvard Civil Rights-Civil Liberties Law Review Vol. N 32 (1997), pp. 105-157.

WISE, Richard; FISHMAN, Clifford; SAFER, Martin, "How to Analyze the Accuracy of Eyewitness Testimony in a Criminal Case", Connecticut Law Review Vol. $\mathrm{N}^{\circ}$ 42, n 3 (2009), pp. 453-513.

WITMER-RICH, Jonathan, "Interrogation and the Roberts Court", Florida Law Review Vol. N 63 (2011), pp. 1189-1243.

ZACHARIAS, Fred; GREEN, Bruce, "The Duty to Avoid Wrongful Convictions: A Thought Experiment in the Regulation of Prosecutors", Boston University Law Review Vol. 89 (2009).

ZALMAN, Marvin, "The Adversary System and Wrongful Conviction”, en: HUFF, Ronald; KILliAS, Martin (Eds.), Wrongful Conviction, International Perspectives on Miscarriages of Justice, Filadelfia: Temple University Press, 2008. 